UNIVERSIDADE DE SÃO PAULO
FACULDADE DE MEDICINA
Programa de Pós-Graduação em Fisiopatologia Experimental

Lívia Mendonça Munhoz Dati

Caracterização das vias de morte celular induzida pela metilecgonidina, produto da pirólise da cocaína.

São Paulo

2012 


\section{Lívia Mendonça Munhoz Dati}

\section{Caracterização das vias de morte celular induzida pela metilecgonidina, produto da pirólise da cocaína.}

Dissertação apresentada à Faculdade de Medicina da Universidade de São Paulo para obtenção do título de Mestre em Ciências

Orientadora: Profa. Dra. Tania Marcourakis

São Paulo

2012 
Dados Internacionais de Catalogação na Publicação (CIP)

Preparada pela Biblioteca da

Faculdade de Medicina da Universidade de São Paulo

Creprodução autorizada pelo autor

Dati, Lívia Mendonça Munhoz

Caracterização das vias de morte celular induzida pela metilecgonidina, produto da pirólise da cocaína / Lívia Mendonça Munhoz Dati. -- São Paulo, 2012.

Dissertação(mestrado)--Faculdade de Medicina da Universidade de São

Paulo.

Programa de Fisiopatologia Experimental.

Orientadora: Tania Marcourakis.

Descritores: 1.Síndromes neurotóxicas 2.Cocaína crack 3.Ratos Wistar 4.Apoptose 5.Necrose 6.Sobrevivência celular/efeitos de drogas 7.Proteínas mitocondriais 8.Caspase 3/efeitos de drogas 9.Receptores muscarínicos

USP/FM/DBD-333/12 
Caracterização das vias de morte celular induzida pela metilecgonidina, produto da pirólise da cocaína.

\author{
Comissão Julgadora \\ da \\ Dissertação para obtenção do grau de Mestre
}

Profa. Dra. Tania Marcourakis

orientador/presidente

$1^{\circ}$. examinador

$2^{\circ}$. examinador 
Dedico todo o meu trabalho à minha família, em especial a minha irmã Camila Mendonça Munhoz Dati pelo carinho, amor, compreensão e força em todos os momentos da minha vida, te amo muito. Ao meu pai Adelino Oikawa Dati e minha mãe Lucy Aparecida Mendonça Munhoz Dati, por serem os melhores pais que alguém pode ter. Amo muito vocês. 
À Profa. Dra. Tania Marcourakis

Agradeço por todo carinho e compreensão durante este processo. 


\section{Agradecimentos}

À Deus por tudo que tem me proporcionado.

À Fundação de Amparo à Pesquisa do Estado de São Paulo, FAPESP, pela bolsa concedida e auxilio financeiro.

Ao Conselho Nacional de Pesquisa, CNPq, pelo auxílio financeiro.

Ao Núcleo de Exames de Entorpecentes do Instituto de Criminalística de São Paulo por ter cedido a cocaína para este estudo, na pessoa da Dra. Gisela Sztulman e Dr. José Luiz da Costa.

À Dra. Maria Regina Lopes Sandoval, à Dra. Solange Castro Afeche e ao Dr. Fernando Abdalla do Instituto Butantan pela colaboração e parceria.

Ao Prof. Dr. Maurício Yonamine pelo apoio na purificação da cocaína e síntese da AEME.

Ao Prof. Dr. Ernani Pinto Junior e ao Dr. Felipe Döor, pela contribuição durante a síntese das substâncias.

Ao aluno de pós-graduação do nosso grupo de pesquisa, Raphael Caio Tamborelli Garcia, pelo apoio, colaboração e amizade.

Aos alunos da Profa. Dra. Tania de pós-graduação: Larissa, Wallace, Ana Carolina pela amizade de todos os dias.

Ao Prof. Dr. Rui Curi e a Profa. Dra. Adriana Levada pela colaboração para a realização e análise dos resultados.

Ao Dr. Tiago de Oliveira pelas discussões, auxilio com as figuras e amizade.

À Dra. Tavane Cambiaghi pela ajuda e por todo carinho e amor, amizade para a vida inteira.

Ao pessoal do laboratório de Farmacologia do Instituto Butantan: Eduardo, Eliza pela ajuda no desenvolvimento deste trabalho.

Aos alunos do Programa de Pós-Graduação em Toxicologia pelos ensinamentos e amizades.

As funcionárias do Laboratório de Análise Toxicológica, Beatriz e Luma pelos momentos maravilhosos e longas conversas, além dos conselhos inesquecíveis.

Aos funcionários da Toxicologia, especialmente à Luzia e Ângelo, por todo o suporte e colaboração. 


\section{RESUMO}

A cocaína é considerada a principal droga de abuso utilizada na América do Sul, sendo que o crack é a via de administração que mais cresceu nos últimos anos. Cabe salientar que o usuário do crack sofre ação tanto da cocaína quanto das substâncias advindas da sua pirólise, dentre elas a metilecgonidina (AEME). Trabalho publicado pelo nosso grupo demonstrou que a AEME é mais neurotóxica que a cocaína em cultura primária de hipocampo. Além disso, dados da literatura têm mostrado uma possível ação da AEME em receptores colinérgicos muscarínicos no sistema nervoso periférico. Na tentativa de elucidar se essa ação ocorre no sistema nervoso central, a AEME foi incubada na presença e na ausência de atropina, um antagonista de receptores colinérgicos muscarínicos. Nossos resultados em cultura primária de hipocampo mostraram que a atropina foi capaz de prevenir os efeitos neurotóxicos causados pela AEME, sugerindo uma afinidade aos receptores colinérgicos muscarínicos. Contudo, o mesmo efeito não foi observado após a incubação com a cocaína e a associação (AEME $1 \mathrm{mM} /$ cocaína $2 \mathrm{mM}$ ). Pode-se pressupor que a AEME age preferencialmente em receptores colinérgicos muscarínicos subtipos $M_{1}, M_{3}$ e $M_{5}$, uma vez que houve a formação de $I_{3}$ e aumento de cálcio intracelular, sendo esse último observado também nos grupos incubados com cocaína e associação (AEME $1 \mathrm{mM}$ /cocaína $2 \mathrm{mM}$ ). Com a finalidade de verificar se a apoptose era uma das vias de morte neuronal, foi avaliada a expressão das proteínas mitoncondriais (Bax e Bcl-2), a atividade da caspase-3 e a análise da fragmentação do DNA, bem como a integridade da membrana celular. Foi observado que a AEME aumentou a razão das proteínas mitocondriais Bax/Bcl-2, a atividade da caspase-3 e o DNA fragmentado, bem como a perda da integridade da membrana. A cocaína aumentou a atividade da caspase- 
3, a fragmentação do DNA e a perda da integridade da membrana celular, mas não alterou a razão da expressão das proteínas mitocondriais Bax/Bcl-2. Apesar de apresentar uma diminuição da atividade da caspase-3, a associação (AEME $1 \mathrm{mM}$ /cocaína $2 \mathrm{mM}$ ) apresentou um aumento do DNA fragmentado e do rompimento da membrana, bem como um aumento da razão Bax/Bcl-2. Estes dados sugerem que estas substâncias estimulam vias de morte neuronal tanto de apoptose quanto de necrose. Mais ainda, nas vias estudas neste trabalho, parece que a associação (AEME $1 \mathrm{mM}$ /cocaína $2 \mathrm{mM}$ ) desencadeia os efeitos neurotóxicos mais rápido, estimulando, possivelmente, vias diferentes das encontradas com as substâncias isoladamente.

Palavras chave: Neurotoxicidade; Cocaína/crack; Metilecgonidina; apoptose; necrose; cultura primária de hipocampo de ratos. 


\section{ABSTRACT}

Cocaine is the main illicit drug used in South America, and the crack cocaine is the administration route that grown more than any other route in the last years. The user of crack cocaine suffers the action of both cocaine and its pyrolysis products, which methylecgonidine (AEME) is the main compound. Published work by our group demonstrated that $A E M E$ is more neurotoxic than cocaine in rat primary hippocampal cell culture. Moreover, published data have shown a possible muscarinic cholinergic action of AEME in the peripheral nervous system. To verify if this action occurs in the central nervous system, AEME was incubated in the presence and absence of atropine, a muscarinic cholinergic receptor antagonist. Our results in rat primary hippocampal cell culture showed that atropine was able to prevent AEME-induced neurotoxic effects, suggesting its affinity for muscarinic cholinergic receptors. However, this effect was not observed after incubation with cocaine and association (AEME $1 \mathrm{mM}$ /cocaine $2 \mathrm{mM}$ ). It is suggestive that AEME acts, with preference, on subtypes $M_{1}, M_{3}$ and $M_{5}$ muscarinic cholinergic receptors, once there was the formation of $\mathrm{IP}_{3}$ and the increase of intracellular calcium. It is important to mention that the intracellular calcium was also increased in both cocaine and association (AEME $1 \mathrm{mM} /$ cocaine $2 \mathrm{mM}$ ) groups. In order to know whether apoptosis was a neuronal death pathway, it was evaluated the expression of mitochondrial proteins (Bax and Bcl-2), the capase-3 activity and the DNA fragmentation, as well as the loss of membrane integrity. It was observed that $A E M E$ increased the ratio of mitochondrial proteins $\mathrm{Bax} / \mathrm{Bcl}-2$, the activity of caspase-3, the fragmentation of DNA and the loss of membrane integrity. Cocaine increased the activity of caspase-3, the DNA fragmentation and the loss of cell membrane integrity, but did not affect the ratio expression of mitochondrial proteins $\mathrm{Bax} / \mathrm{Bcl}-2$. Although it was observed a decrease 
in caspase-3 activity, the association (AEME $1 \mathrm{mM} /$ cocaine $2 \mathrm{mM}$ ) showed an increase in the DNA fragmentation and the cell membrane disruption, as well as an increase in $\mathrm{Bax} / \mathrm{Bcl}-2$ ratio. These data suggest that these substances stimulate neuronal death pathways of both apoptosis and necrosis. Moreover, in the pathways studied in this work, it seems that the association (AEME $1 \mathrm{mM} /$ cocaine $2 \mathrm{mM}$ ) has the fastest neurotoxic effects, stimulating, possibly, different neuronal death pathways when compared to substances isolated.

Key Words: neurotoxicity; crack cocaine; anhydroecgonine methyl ester; apoptosis; necroses; rat primary hippocampal cell culture. 


\section{Índice de Figuras}

Figura 1. Porcentagem mundial de usuários de cocaína em 2008.

Figura 2. Pirólise da cocaína formando metilecgonidina .6

Figura 3. Sinalização intracelular com ativação de proteínas mitocondriais 13

Figura 4. Via de sinalização intracelular estimulada por PI3K (fosfatidilinositol 3quinase) 15

Figura 5. Representação esquemática de duas vias de sinalização de morte celular: intrínseca e extrínseca. .16

Figura 6. Curva de $\operatorname{MTT}(n=5)$ após exposição de $3 ; 6 ; 12 ; 24 ; 48$ horas a concentrações equipotentes de AEME e COC e associação das mesmas $(A+C) \ldots .24$

Figura 7. Ensaio de $\operatorname{LDH}(n=5)$ após 24 horas de exposição e 48 horas de exposição. .25

Figura 8. Resultados de viabilidade celular (MTT) após 24 horas de exposição com AEME em diferentes concentrações $(n=5)$.

Figura 9. Resultados de viabilidade celular (MTT) após 24 horas de exposição à cocaína em diferentes concentrações $(n=6)$.

Figura 10. Resultados de viabilidade celular (MTT) após 24 horas de exposição à associação (AEME 1mM /cocaína 2 mM) em diferentes concentrações ( $n=6)$.

Figura 11. Resultado da padronização do método para verificar a formação de $\mathbb{I P}_{3}$ em neurônios, expostos ao carbacol, um agonista colinérgico muscarínico inespecífico. 
Figura 12. Resultados da formação de IP3 em neurônios, incubados com AEME em diferentes concentrações $(n=5)$.

Figura 13. Ensaios da concentração de cálcio intracelular em neurônios $(n=10) \ldots . .50$

Figura 14. Integridade da membrana celular da cultura primária de hipocampo $(n=3)$.

Figura 15. Imagens representativas da análise por citometria de fluxo, para determinação da integridade da membrana celular.

Figura 16. Integridade da membrana celular da cultura primária de hipocampo $(n=4)$.

Figura 17. Imagens representativas da análise por citometria de fluxo, para determinação da integridade da membrana celular.

Figura 18. Fragmentação do DNA da cultura primária de hipocampo após a exposição à AEME, cocaína e associação (AEME $1 \mathrm{mM}$ /cocaína $2 \mathrm{mM}$ ) por 12 horas $(n=3)$. .55

Figura 19. Imagens representativas da análise por citometria de fluxo, para a determinação da fragmentação do DNA

Figura 20. Fragmentação do DNA da cultura primária de hipocampo após a exposição à AEME, cocaína e associação (AEME $1 \mathrm{mM}$ /cocaína $2 \mathrm{mM}$ ) por 24 horas $(n=3)$.

Figura 21. Imagens representativas da análise por citometria de fluxo, para a determinação da fragmentação do DNA

Figura 22. Imagens representativas das membranas de nitrocelulose coradas com Ponceau 
Figura 23. Expressão de proteínas mitocondriais Bax e Bcl-2 em cultura primária de hipocampo $(n=4)$. 60

Figura 24. Razão entre as proteínas mitocondriais Bax e Bcl-2 em cultura primária de hipocampo $(n=4)$. .60

Figura 25. Expressão de proteínas mitocondriais Bax e Bcl-2 em cultura primária de hipocampo $(n=4)$. 61

Figura 26. Razão entre as proteínas mitocondriais Bax e Bcl-2 em cultura primária de hipocampo $(n=4)$. 62

Figura 27. Expressão de proteínas mitocondriais Bax e Bcl-2 em cultura primária de hipocampo $(n=4)$. .63

Figura 28. Razão entre as proteínas mitocondriais Bax e Bcl-2 em cultura primária de hipocampo $(n=4)$.

Figura 29. Resultados dos ensaios da atividade da caspase-3 em neurônios ( $n=4) .64$

Figura 30. Resultados dos ensaios da atividade da caspase- 3 em neurônios $(n=4) .65$ Figura 31. Resultados dos ensaios da atividade da caspase -3 em neurônios $(n=4) .66$

Figura 32. Semelhança estrutural entre AEME e arecolina. .70

Figura 33. Sinalização intracelular induzida pela AEME em cultura primária de hipocampo. .74

Figura 34. Sinalização intracelular estimulada pela cocaína .77 
Figura 35. Sinalização intracelular induzida pela associação (AEME 1 mM /cocaína 2

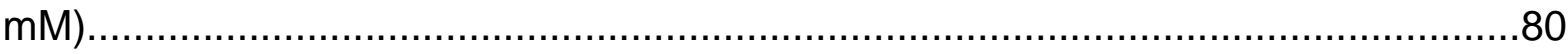


Índice de Tabela

Tabela 1. Principais diferenças morfológicas das células em apoptose e necrose...17 


\section{Lista de Anexos}

Anexo 1. Protocolo $n^{\circ}$ aprovado pela Comissão de Ética no Uso de Animais da Faculdade de Medicina da USP.

Anexo 2. Protocolo $n^{\circ} 633 / 09$ aprovado pela Comissão de Ética no Uso de Animais do Instituto Butantan.

Anexo 3. Artigo publicado na revista Toxicological Science, 2012.

Anexo 4. Ficha do aluno (Sistema Janus/USP).

Anexo 5. Currículo Lattes. 


\section{Sumário}

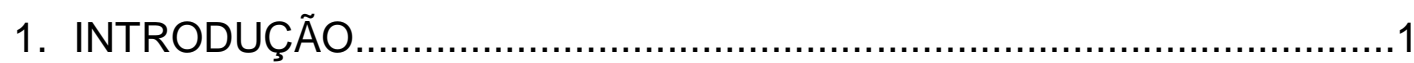

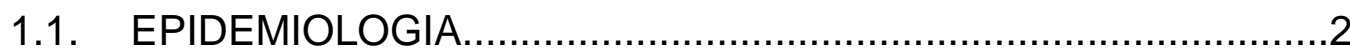

1.2. CRACK

1.3. COCAÍNA E AEME: MECANISMO DE AÇÃO E EFEITOS.............6

1.4. MECANISMOS DE MORTE NEURONAL...................................

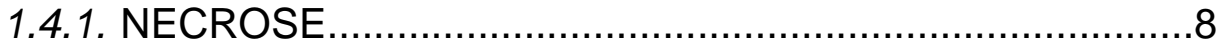

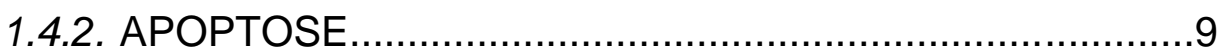

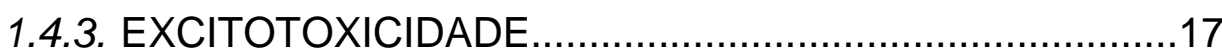

1.4.4. ESTRESSE OXIDATIVO............................................19

1.5. RECEPTORES MUSCARÍNICOS E SISTEMA NERVOSO

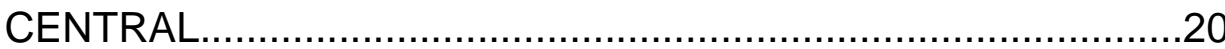

1.6. EFEITOS DA COCAÍNA/CRACK NA MORTE NEURONAL........22

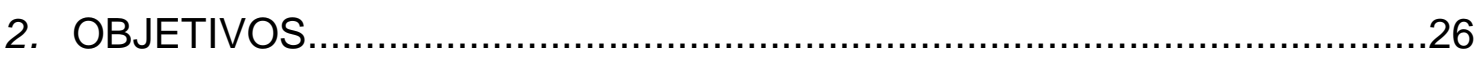

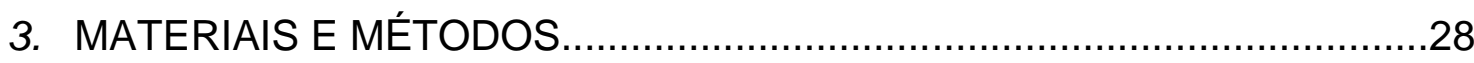

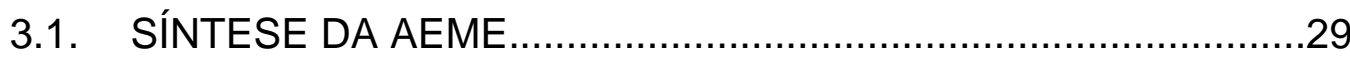

3.2. DELINEAMENTO EXPERIMENTAL_.......................................29

3.3. CULTURA DE CÉLULAS........................................................30

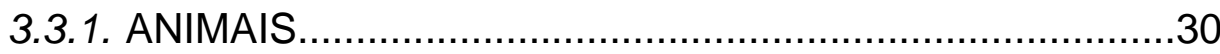

3.3.2. CULTURA DE NEURÔNIOS HIPOCAMPAIS...................30

3.3.3. DISSOCIAÇÃO DE CÉLULAS HIPOCAMPAIS

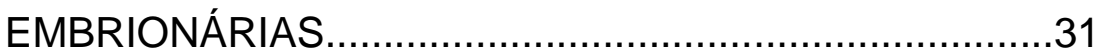

3.4. PARTICIPAÇÃO DOS RECEPTORES COLINÉRGICOS MUSCARÍNICOS NA AÇÃO DA AEME. .33 
3.5. DETERMINAÇÃO DA FORMAÇÃO DE FOSFATO DE INOSITOL (MONO-BI E TRIFOSFATO DE INOSITOL) EM HIPOCAMPO...34

3.6. MEDIDA DO CÁLCIO INTRACELULAR EM CULTURA DE NEURÔNIOS HIPOCAMPAIS POR MICRSCOPIA

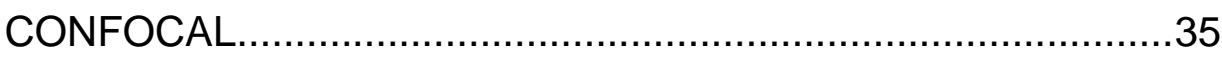

3.7. ANÁLISE DE INTEGRIDADE DA MEMBRANA...........................37

3.8. ANÁLISE DA FRAGMENTAÇÃO DE DNA POR CITOMETRIA DE

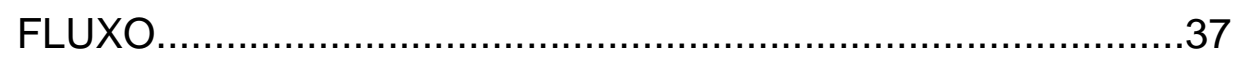

3.9. QUANTIFICAÇÃO DAS PROTEÍNAS BCL-2 E BAX..................38

3.10. ATIVIDADE DA CASPASE-3................................................ 41

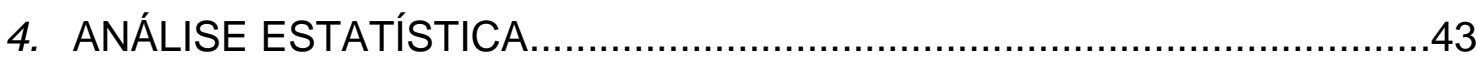

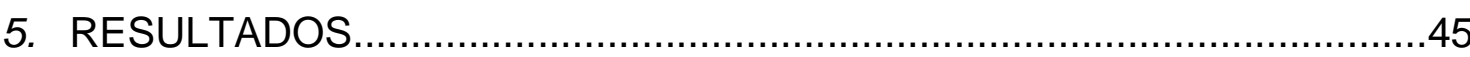

5.1. ENVOLVIMENTO COM RECEPTOR COLINÉRGICO

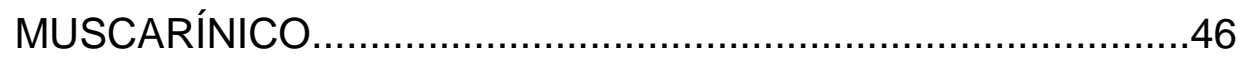

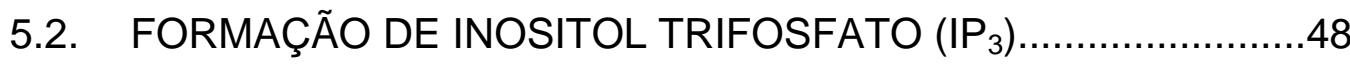

5.3. CONCENTRAÇÃO DE CÁLCIO INTRACELULAR......................49

5.4. INTEGRIDADE DA MEMBRANA CELULAR.............................50

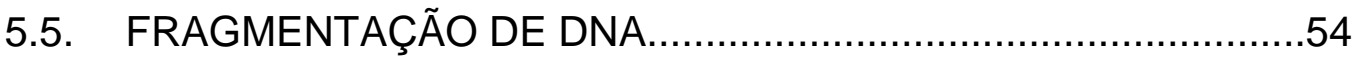

5.6. EXPRESSÃO DE PROTEÍNAS MITOCONDRIAIS: BAX E BCL-

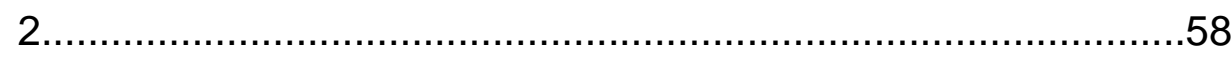

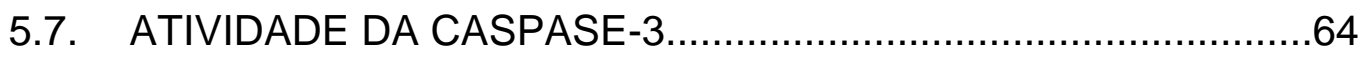

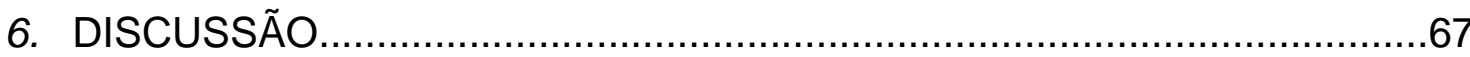

6.1. AEME, COCAÍNA E ASSOCIAÇÃO (AEME $1 \mathrm{mM} /$ COCAÍNA 2 mM) E RECEPTOR MUSCARÍNICOS......................................68

6.2. VIAS DE MORTE NEURONAL.............................................71 
7. CONCLUSÃO.

8. REFERÊNCIAS BIBLIOGRÁFICAS... 
Parte destes resultados foram publicados na revista Toxicological Science, 2012, com o titulo: Neurotoxicity of anhydroecgonine methyl ester, a crack cocaine pyrolysis product.

$\mathrm{O}$ artigo encontra-se anexo 3. 
1.INTRODUÇÃO 


\subsection{EPIDEMIOLOGIA}

O aumento do número de usuários de drogas que afetam o sistema nervoso central (SNC), como a anfetamina, a cocaína e o tabaco, é considerado um problema de saúde pública. Dentre estas substâncias, a cocaína, um alcalóide proveniente das folhas do gênero Erytroxylum ( $E$. novogranatense e E. coca), merece destaque por, além de ser um potente anestésico local, também apresenta ação estimulante no SNC (CRITSCHRISTOPH et al., 2009).

O uso da cocaína como fármaco iniciou-se por volta de 1898, quando pesquisadores norteamericanos a utilizaram na tentativa de substituir a morfina, já que esta tinha uma alta tendência em causar dependência. Apesar das empresas farmacêuticas retirarem a cocaína de circulação após a identificação de seu também potencial de dependência, o uso ilegal continuou e persiste até os dias atuais (FERREIRA \& MARTINI, 2001).

Aproximadamente 14 milhões de pessoas no mundo utilizam a cocaína de forma indiscriminada (CUNHA et al., 2004). Diversos grupos de pesquisa tiveram como objetivo avaliar o perfil destes usuários, visto que houve um aumento neste número, acarretando em consequências sociais e econômicas para os países. No Brasil, um importante estudo foi realizado pelo Centro Brasileiro de Informações sobre Drogas Psicotrópicas (CEBRID) da Universidade Federal de São Paulo (UNIFESP), o "Levantamento Domiciliar sobre o uso de Drogas Psicotrópicas no Brasil", realizado em 2001 e em 2005. O primeiro estudo mostrou que $19,4 \%$ da população brasileira já utilizou alguma substância química pelo menos uma vez na vida (uso na vida), excetuando-se o álcool e o tabaco. Esta porcentagem é aproximadamente a 
metade da porcentagem encontrada nos Estados Unidos que é em torno de 38,9\%. Em 2005 foi realizado um novo levantamento, com 7.939 pessoas entrevistadas entre 12 e 65 anos em 108 cidades. $O$ uso na vida para qualquer substância, com exceção do álcool e do tabaco, foi de $22,8 \%$, semelhante ao do Chile (23,4\%). Mais uma vez, o Brasil obteve um índice que corresponde, aproximadamente, a metade do valor dos Estados Unidos (45,8\%). De 2001 até 2005 , pode-se observar um acréscimo de 3,4\%, sugerindo um aumento importante no uso de drogas de abuso.

O relatório mundial sobre drogas publicado em 2012 pela UNODC (United Nations Office on Drugs and Crime), o "World Drug Report (2012)", mostrou que o número de pessoas no mundo que usam cocaína aumentou de 0,3 a 0,4\%. De acordo com este relatório, as regiões que obtiveram maior prevalência do uso de cocaína foram: América do Norte (1,6\%), Centro e Oeste da Europa (1,3\%) e Oceania (1,5 a 1,9\%), com destaque para a Austrália e a Nova Zelândia. Na figura 1 pode-se observar o uso de cocaína no mundo em 2010, período em que foi realizado este levantamento. Os países da América do Norte e da Oceania apresentaram o maior número de usuários de cocaína, porém, países da América do Sul também apresentaram uma quantidade considerável de pessoas que utilizaram cocaína. 


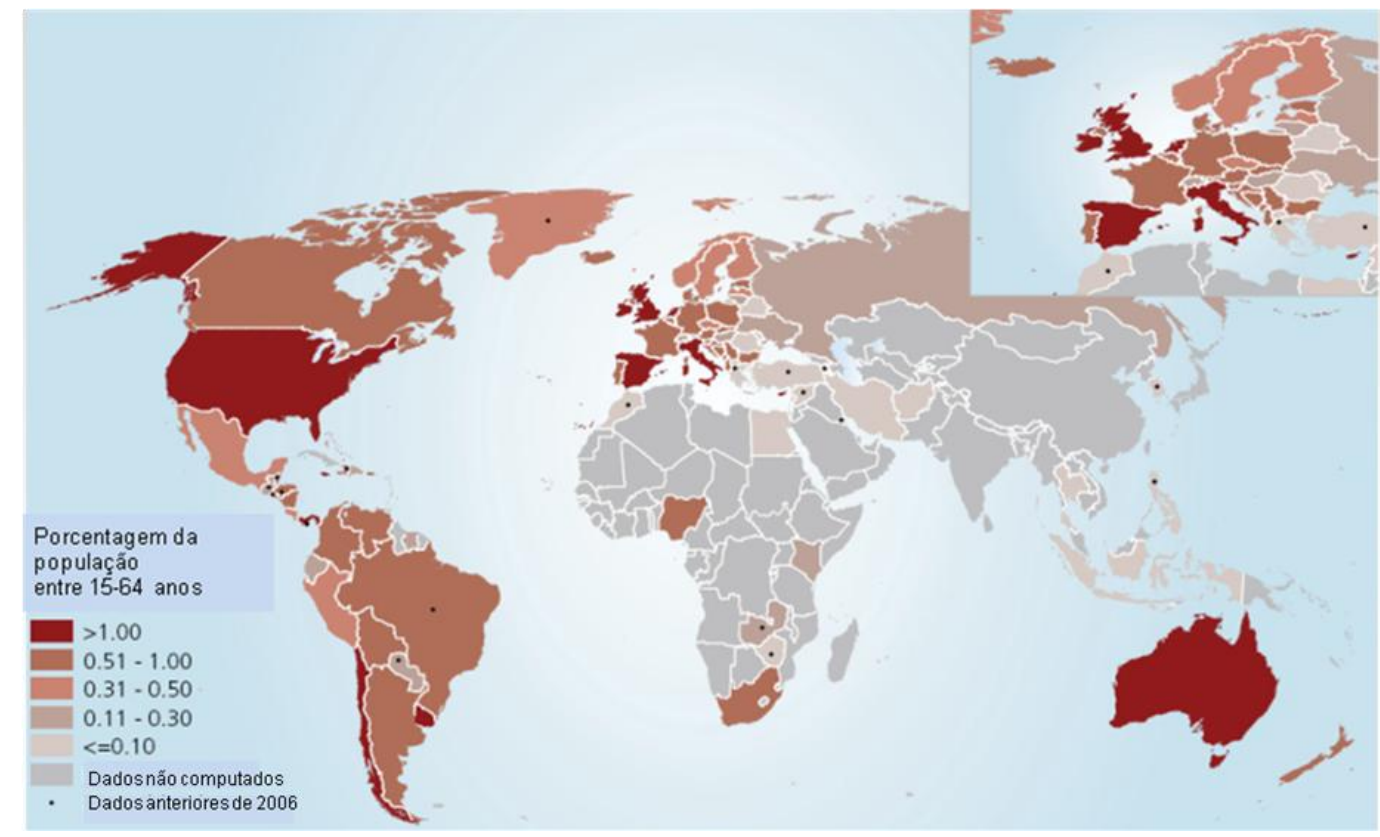

Figura 1. Porcentagem mundial de usuários de cocaína em 2008, considerando a porcentagem em cada país (traduzido e adaptado do relatório mundial sobre drogas publicado em 2012 pela UNODC).

\subsection{CRACK}

O crack é obtido pela mistura de cloridrato de cocaína com bicarbonato de sódio, formando uma substância sólida com formato irregular parecido com uma pedra (crack), nome utilizado popularmente. O aquecimento da "pedra" promove a sublimação da cocaína, a qual é fumada (CHASIN et al., 2008), o que faz do crack a forma inalatória de administração de cocaína.

O crack tem sido a principal forma de uso desta droga em função da alta velocidade de absorção da cocaína, com início de seus efeitos quase que imediatamente, em aproximadamente 5 minutos (JULIEN, 1995). Contudo, esta forma de uso da cocaína tem absorção e tempo de ação mais lenta quando comparada à administração pela via intravenosa (IV) (CHASIN \& MÍDIO, 1997). Entretanto existem outros fatores facilitadores para o uso do crack como a facilidade de aquisição e de uso, além do baixo custo. 
O rápido efeito ocorre, pois a via inalatória facilita a absorção dos compostos pela corrente sanguínea. Isto ocorre porque, quando aspirados, os constituintes do crack são absorvidos pelos pulmões, órgão extremamente vascularizado possibilitando à rápida absorção para a corrente sanguínea, provocando as alterações fisiológicas, principalmente ao atingir o SNC (O'BRIEN, 2006).

O tempo de ação da cocaína quando se utiliza o crack é cerca de cinco vezes menor do que quando a cocaína é administrada via IV, atingindo em torno de 10 a 30 minutos. Um dos fatores que contribui para o uso contínuo de crack é a rápida diminuição da concentração plasmática da cocaína, com consequente redução dos efeitos prazerosos desencadeados pelo seu uso. Isso faz com que o usuário de crack passe a usar novamente a droga, possivelmente, tornando-o dependente mais rapidamente quando comparado às demais vias de administração da cocaína.

A cocaína é rapidamente biotransformada no fígado em éster metilecgonina (EME) e benzoilecgonina (BE), os quais são encontrados na urina do usuário. Além destes compostos, ainda podem ser encontrados, porém, em concentrações mais baixas, outros produtos como ecgonina, norcocaína e benzoilnorecgonina.

Durante o fumo do crack, ocorre a produção da metilecgonidina, também chamada de anidroecgonina metil éster (AEME), como mostrado na figura 2, um composto formado durante a decomposição térmica ou pirólise da cocaína. Este composto, assim como a cocaína, é absorvido em quantidades consideráveis após o uso do crack (FANDIÑO et al., 2002). 


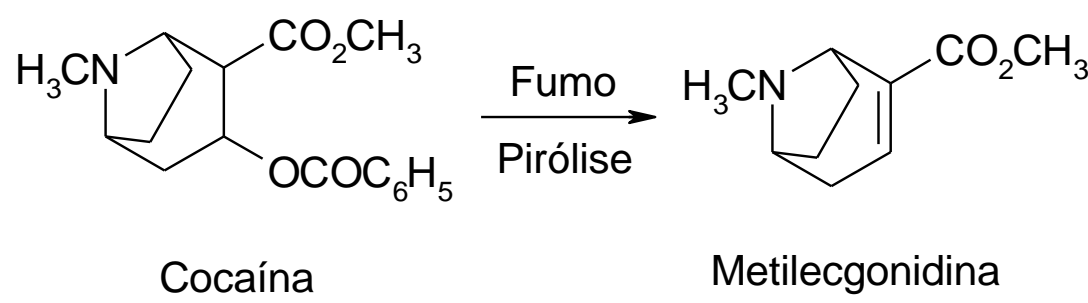

Figura 2. Pirólise da cocaína formando metilecgonidina, reação que ocorre durante o uso de crack (Paul et al., 1999).

\subsection{COCAÍNA E AEME: MECANISMO DE AÇÃO E EFEITOS}

A ação da cocaína ocorre tanto no SNC quanto no periférico. No SNC, a cocaína bloqueia a recaptura de dopamina nas fendas sinápticas devido a sua ligação aos transportadores de dopamina (GIROS et al., 1996). Como consequência, ocorre o acúmulo de dopamina na fenda sináptica, a qual poderá interagir com os receptores dopaminérgicos. A ativação de receptores dopaminérgicos dos subtipos $D_{1}, D_{2}$ e $D_{3}$ em regiões encefálicas, como 0 estriato (núcleo accubens), bulbo olfatório, córtex pré-frontal, substância negra e amígdala são responsáveis pelos efeitos estimulantes da cocaína.

A cocaína também exerce ação em outros sistemas fisiológicos, como é o caso do cardiovascular e pulmonar, desencadeando problemas de saúde graves, como por exemplo: arritmia cardíaca, isquemia do miocárdio, miocardite, vasoconstrição cerebral, convulsões, edema pulmonar, reações de hipersensibilidade pulmonar, hemorragia alveolar, hipertensão pulmonar, pneumonia, entre outras (O' BRIEN, 2006).

Pouco se sabe em relação aos mecanismos de ação e efeitos da AEME. Em função de sua semelhança estrutural à arecolina, um agonista de receptor colinérgico muscarínico (JACOB et al., 1990), foi postulado uma possível ação muscarínica da AEME. Assim, estudo realizado por HUANG et al. (1997), avaliaram a ação da AEME em cardiomiócitos, mostrando uma diminuição da 
contração das fibras musculares. O possível mecanismo envolvido seria mediado pela ação em receptores colinérgicos muscarínicos subtipo $M_{2}$, que leva à diminuição na concentração intracelular de cálcio. SCHEIDWEILER et al. (2003), mostraram que a AEME induziu taquicardia e hipotensão quando administrada via intravenosa em ovelhas. Assim, foram propostos dois mecanismos de ação para esta substância: 1) a AEME age nos receptores muscarínicos $M_{3}$ no epitélio vascular que estimula o óxido nítrico sintetase desencadeando a produção do óxido nítrico (NO), relaxando a musculatura; 2) a ação da $A E M E$ nos receptores muscarínicos $\mathrm{M}_{2}$, diminui a força de contração cardíaca, pela inibição de adenilil ciclase e estimulação da guanilil ciclase que induz a queda da pressão arterial. A possível ação muscarínica da AEME foi corroborada por YANG et al. (2001) que demonstraram que tanto a AEME quanto a cocaína interagem com os receptores muscarínicos $M_{2}$ o que leva à produção do segundo mensageiro GMPc, em cultura de células HEL299.

Por meio de experimento de binding, nosso grupo de pesquisa (GARCIA et al., 2012) mostrou que a AEME é capaz de se ligar aos receptores muscarínicos , apresentando pKi semelhante ao da arecolina.

De acordo com a Organização Mundial da Saúde (OMS, 2007), o uso crônico e/ou agudo de cocaína pode provocar acidente vascular encefálico do tipo isquêmico ou hemorrágico. A cocaína pode ainda alterar o funcionamento eletrofisiológico encefálico, resultando em uma sincronização anormal das atividades elétricas dos neurônios, os quais alteram os potenciais elétricos durante a despolarização e repolarização, mecanismos estes de extrema importância para que a comunicação neuronal ocorra com eficiência. Apesar de estas alterações serem observadas com mais frequentes em usuários crônicos, 
também podem ocorrer na primeira vez de uso, por exemplo, desencadeando crises epilépticas. Entretanto, a probabilidade é duas vezes maior nos indivíduos com histórico de doença neurológica (BOGHDADI \& HENNING, 1997). As alterações fisiológicas causadas pelo uso da cocaína podem ser letais, principalmente quando associadas à hipertermia, acidose sistêmica, disritmia e parada cardíaca (OMS, 2007).

É importante destacar que durante o uso do crack, há a inalação tanto da cocaína quanto da AEME, estando o usuário sujeito ao efeito de ambas as substâncias. Algumas reações como excitabilidade, hiperatividade, insônia, perda da sensação de cansaço, falta de apetite e perda da noção de higiene foram relatadas nesses usuários. A falta de apetite é característica do usuário de crack, podendo haver a perda de 8 a $10 \mathrm{Kg}$ em menos de um mês (CEBRID, 2003).

\subsection{MECANISMOS DE MORTE NEURONAL}

A morte celular pode ocorrer por estímulo proveniente da própria célula ou decorrente de fatores externos tóxicos que ativam as vias de morte celular. Vários mecanismos podem levar à morte neuronal, entre eles destaca-se a necrose e a apoptose, a excitotoxicidade e o estresse oxidativo.

\subsubsection{NECROSE}

A morte celular por necrose é caracterizada por um processo patológico, pois quando ativado, estimula a ação do sistema imunológico. Este tipo de morte pode ser desencadeado em condições extremas como hipóxia, isquemia, intoxicação, abuso de drogas e por reações autoimunes das células vizinhas. A 
membrana plasmática fica danificada, o que provoca perda da proteção celular, aumento do volume citoplasmático e mitocondrial, além de extravasamento do conteúdo intra para o extracelular. Esta mudança na constituição da célula gera uma resposta inflamatória, com ativação de fatores do sistema imune, como linfócitos, macrófagos, interleucinas e fatores de transcrição. Contudo, a ativação deste sistema causa também o comprometimento das células vizinhas e do ambiente (CURTIN et al., 2002), o que pode desencadear morte em cadeia.

Durante o processo de necrose ocorre também alterações da função mitocondrial, diminuindo a produção de ATP e, consequentemente, inibindo a bomba de $\mathrm{Na}^{+} / \mathrm{K}^{+}$-ATPase, provocando o inchaço celular devido ao aumento de íons sódio no citoplasma da célula. Ocorre ainda o aumento de cálcio no citosol que desencadeia na ativação de fosfolipases e de proteases, induzindo ao aumento de espécies reativas de oxigênio (EROS), as quais induzem a ruptura da membrana plasmática e a ativação de mais proteases, provocando o extravasamento do conteúdo celular (MCCONKEY, 1998).

\subsubsection{APOPTOSE}

A apoptose é um fenômeno de morte celular programado. Este processo é importante para remover células antigas ou infectadas. De forma diferente da necrose, a apoptose não envolve sinalização para um processo inflamatório (ROSSER \& GORES, 1995).

A morte celular por apoptose é um processo importante que ocorre constantemente no organismo de forma fisiológica e induzida por agentes tóxicos. Este processo mantém a homeostase e o desenvolvimento 
embrionário. Em adultos, a apoptose é responsável pelo balanço entre a proliferação e a manutenção celular em cada tecido para que não haja crescimento acelerado e descontrolado, o que poderia possibilitar o surgimento de tumores (DANIAL \& KORSMEYER, 2004). Além disso, promove a defesa do organismo eliminando as células sem causar prejuízos. A apoptose ocorre em momentos importantes para o desenvolvimento da espécie. Em humanos, por exemplo, ocorre durante o desenvolvimento do sistema nervoso central quando há excesso de neurônios. Aproximadamente 50\% destes são eliminados por este tipo de morte (JACOBSON et al., 2004).

As células em apoptose apresentam características morfológicas específicas como condensação da cromatina, fragmentação do DNA, perda da aderência ao tecido adjacente e às estruturas especializadas, como as microvilosidades. Detalhadamente, durante o processo ocorre a formação de vacúolos citoplasmáticas, sendo que a célula perde líquido e se divide formando pequenos fragmentos, chamados de corpos apoptóticos. Estes corpos são fagocitados pelos macrófagos ou por células vizinhas, sem produzir sinal de inflamação (NETTO \& FERRAZ, 2000). A remoção dos corpos apoptóticos é mediada por fosfatidilserinas presentes na membrana plasmática. Durante o processo apoptótico, as fosfatidilserinas são expressas na membrana e reconhecidas por receptores de células fagocíticas (LAUBER et al., 2004).

A apoptose pode ser deflagrada por estímulos externos por meio da ativação de receptores específicos de morte localizados na membrana celular (via extrínseca), chamados de receptores de morte, ou pelo estresse intracelular (via intrínseca ou mitocondrial) (DRAGOVICH et al., 1998). Desde 
1986 há estudos sobre a possível influência da genética sobre este processo. Foi identificada a presença dos genes ced-3, ced-4 e ced-9, sendo que os dois primeiros favorecem a apoptose enquanto que o último a inibe (MOHAMAD et al., 2005).

A ativação do processo de morte induzida por fatores intracelulares é geralmente classificada como iniciadora ou efetora das caspases, que tem ação em cascata. As caspases são sintetizadas como um precursor inativo que pode ser convertido em ativo por clivagem proteolítica por outras caspases (REED, 2000).

Estudos com C. elegans (nematóide da família Rhabditidae) sugeriram que a ced-4 ativa a ced-3 e a caspase- 9 , enquanto que, em humanos, a ced-4 possui um homólogo, a Apaf-1 (Apoptotic Protease-Activating Factor 1) que se liga a caspase e promove a ativação do processo apoptótico induzido pela caspase. A Apaf-1, por sua vez, é um complexo de multisubunidades conhecido como apoptossomo e sua formação requer a presença do citocromo c, liberado pela mitocôndria por estímulo apoptótico. Uma vez que o apoptossomo foi formado, a caspase-9 cliva e estimula a clivagem das demais caspases (Figura 3), como a caspase-7 e a caspase-3. A autorregulação das caspases e a inativação de proteínas são mecanismos cruciais para a manutenção do citoesqueleto celular, reparo do DNA, sinais de transdução e controle do ciclo celular (FRASER \& EVAN, 1996; NAGATA, 1997).

Neste processo de morte celular, o gene Ced-9 pode ser encontrado em mamíferos com o nome de Bcl-2 e possui importantes influências para o desenvolvimento e o progresso deste processo. Alguns membros desta família são inibidores de apoptose enquanto outros são ativadores ou promotores da 
morte celular. Estes membros são homólogos, diferentes apenas na extensão do gene para $\mathrm{Bcl}-2$. O balanço entre as classes pró e antiapoptóticas é determinante para manter a viabilidade de uma célula (FISAR \& HROUDOVÁ, 2010).

Os membros das famílias da $\mathrm{Bcl}-2$ estão presentes na mitocôndria, organela que comanda a morte celular. Quando ativados, os oligômeros próapoptóticos Bax e Bak são acoplados na membrana da mitocôndria. A formação dos oligômeros faz com que o citocromo $c$ seja liberado pelo espaço intramembrânico, através de poros ou pela interação com outras proteínas da membrana (GOTTLIEB, 2000). A liberação do citocromo $c$ forma, junto com Apaf-1 e a pró-caspase-9, o apoptossomo, o qual ativará a cascata das caspases (LI et al., 2003; REED, 1998; SLEE et al., 1999; DESAGHER \& MARTINOU, 2000; KUIDA, 2000). Portanto, a ativação de Bax ou Bak resulta na formação do apoptossomo que desencadeia morte celular por ação das caspases (NUÑEZ et al., 1998).

A caspase é inativada por uma família de proteínas inibidoras da apoptose ou IAPs (inhibitor of apoptosis). Estas proteínas agem por meio da inibição da atividade das caspases ou por ubiquitinação, degradando os proteassomas, que são um conjunto de proteínas que precisam interagir para serem ativados. Durante a liberação do citocromo $c$ pela mitocôndria, são liberadas também outras proteínas chamadas Smac/Diablo e Omi/Htr2, que estimulam a ativação das caspases por interagir com as IAPs tornando-as inativas (VAUX \& SILKE, 2005) (Figura 3). 


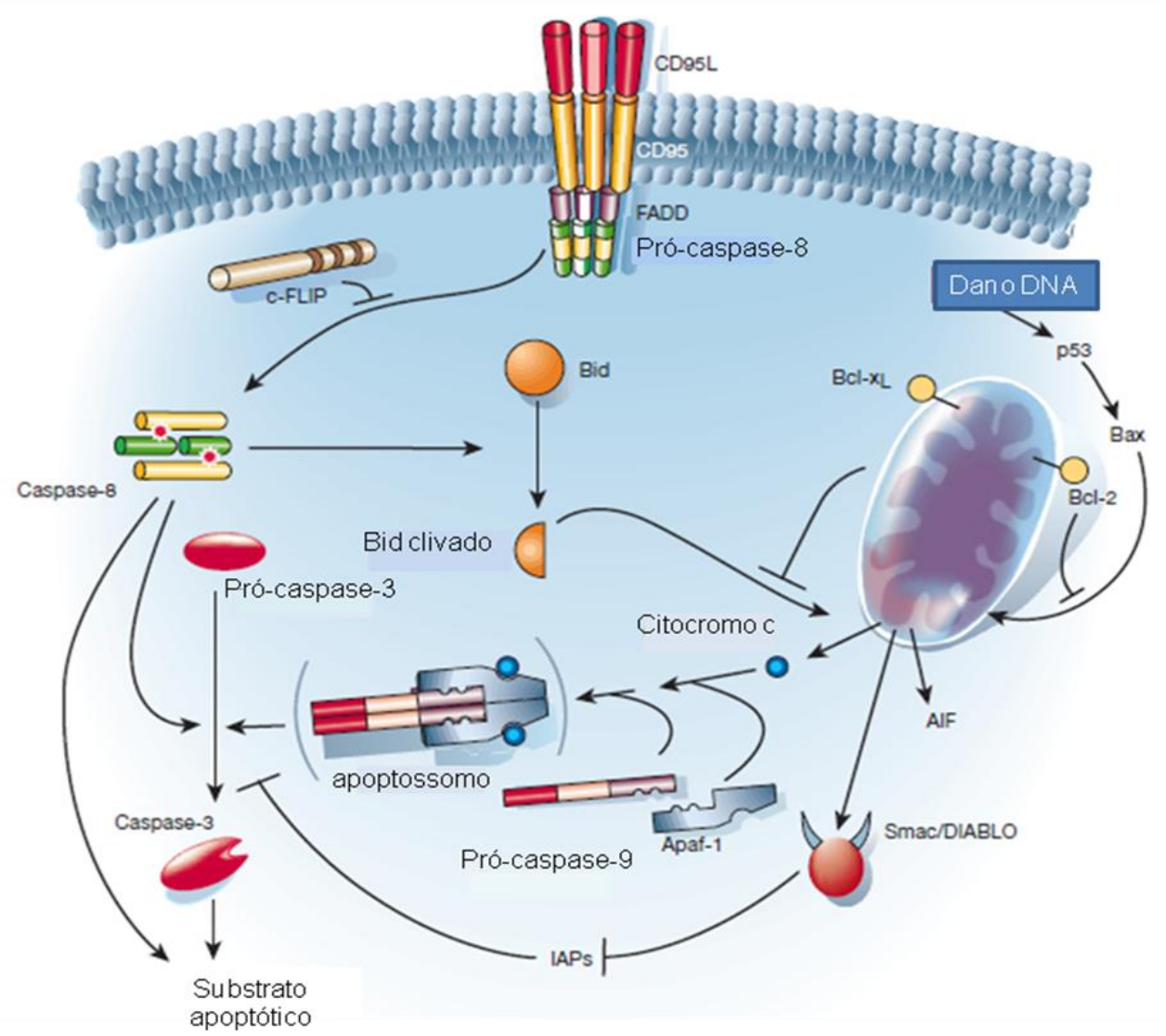

Figura 3. Sinalização intracelular com ativação de proteínas mitocondriais. A interação do ligante CD95 com o seu receptor induz a formação de um complexo que recruta fator de morte celular, representado por FADD. Este, por sua vez, cliva a pró-caspase-8 e, consequentemente, ativa a caspase-8 que age clivando a pró-caspase-3 em caspase-3, responsável pela formação de substratos apoptóticos. A clivagem da pró-caspase-8 pode ser inibida por uma proteína presente no citosol celular (chamada c-FLIP). A morte celular pode ser desencadeada por estimulação da via mitocondrial em resposta à sinalização extracelular e por danos ao DNA. Há ativação de membros pró-apoptóticos, como o caso da proteína Bax, que estimula a formação de poros na mitocôndria, liberando citocromo $c$ que, juntamente com a Apaf-1 e a pró-caspase-9, formam o apoptossomo. Esse complexo cliva a pró-caspase-3, ativando a caspase-3. Além do citocromo c, há liberação da AIF (flavoproteína com grande potencial para apoptose) e da Smac/DIABLO que inibem a ação das IAPs (proteína capaz de inibir a clivagem da pró-caspase-3). Além disso, pode ocorrer a clivagem da proteína Bid por meio da caspase-8, estimulando a liberação de citocromo c pela mitocôndria. As linhas que terminam em setas representam ativação, enquanto que as que terminam em traço representam inibição (Modificado de HENGARTNER, 2000).

Outro fator capaz de induzir apoptose é o fator de transcrição p53. As proteínas quinases CHK e ATM, ativadas por danos ao DNA, fosforilam e estabilizam o p53 (em determinados pontos do ciclo celular). $O$ aumento do p53 ativa seu próprio fator transcricional o qual induz apoptose, pois está acoplado a membros da família de proteínas pró-apoptóticas, como PUMAS e 
Noxa (conhecidas por induzir a permeabilidade da membrana mitocondrial de forma indireta, estimulando as proteínas pró-apoptótica Bax e Bad). O p53 pode regular tanto a morte celular quanto o ciclo celular, dependendo dos níveis que foram induzidos pelo DNA (SILVA \& ZUCOLOTO, 2002; GRIVICICH et al., 2007).

Outra via possível para o desencadeamento de morte é por meio de fatores de crescimento neuronal (NGF), que induzem tanto morte neuronal quanto diferenciação pela ativação de receptores de proteína quinase. Além disso, ainda há células que dependem da ativação de não-receptores de proteína quinase associada às integrinas para desencadear a morte.

Por outro lado, as células possuem vias que visam a sobrevivência, sendo que uma delas é mediada pela enzima fosfatidilinositol 3-quinase (PI3quinase), ativada por proteínas-tirosina quinase ou por ação em receptor acoplado a proteína G. A PI3-quinase fosforilada age no fosfolipídio de membrana $\mathrm{PIP}_{2}$ (4,5-bifosfato de fosfatidilinositol) para formar $\mathrm{PIP}_{3}(3,4,5$ trifosfato de fosfatidilinositol), que ativa a proteína quinase Akt (serina/treonina proteína quinase) (VANHAESEBROECK et al., 1997). Esta proteína é capaz de fosforilar diversas proteínas celulares para a sobrevivência da célula, dentre elas a Bad (familia da Bcl-2 pró-apoptótica). A fosforilação da Bad pela Akt cria um sitio de ligação para chaperona que deixa a Bad na forma inativa, inibindo a apoptose e promovendo a sobrevivência da célula. Além da Akt, outras proteínas quinases agem na Bad deixando-a inativa, como Ras (DATTA et al., 1999) (Figura 4). 

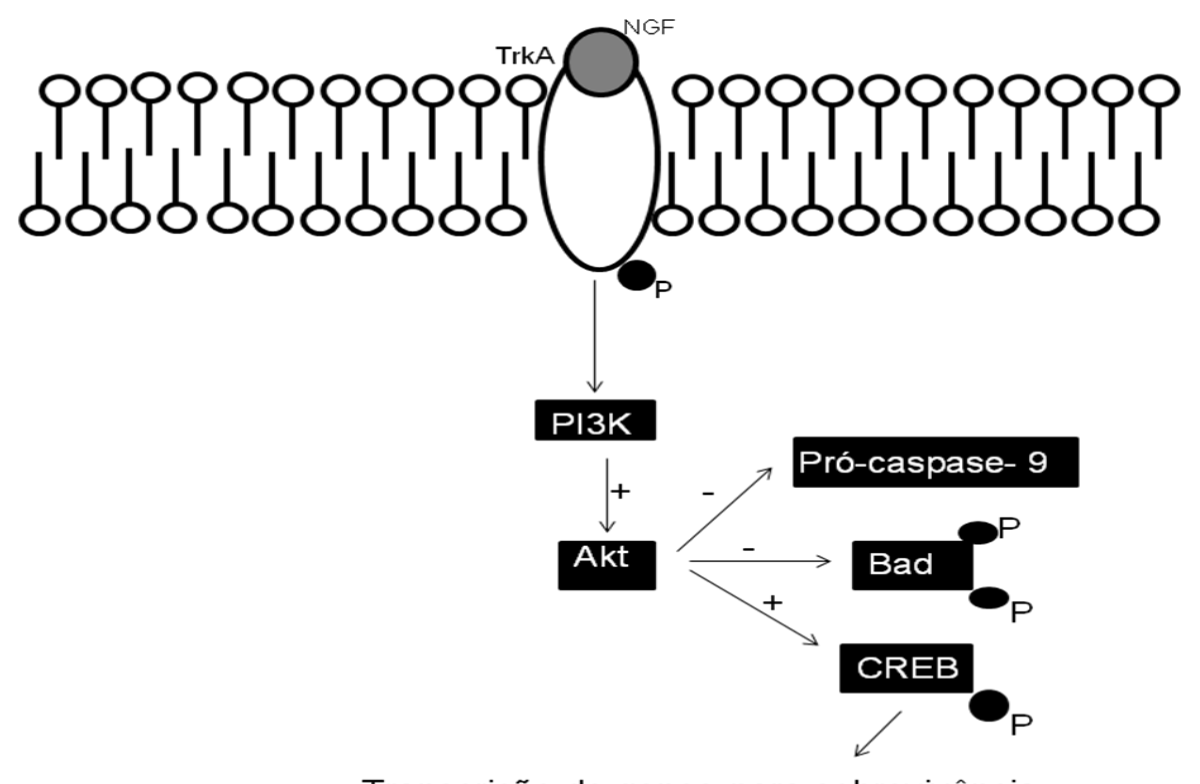

Figura 4. Via de sinalização intracelular estimulada por PI3K (fosfatidilinositol 3-quinase). A ativação da PI3K ocorre por proteínas tirosina quinase (TrkA) ou pela interação com receptor acoplados a proteína $\mathrm{G}$, como o receptor neurotrófico que é ativado por ligantes como fator de crescimento celular (NGF). Quando ativado o receptor tem um domínio intracelular que é fosforilado, recrutando lipídeo de membrana que culmina na formação do PI3K, o qual fosforila a proteína quinase (Akt), ativando-a. A Akt, quando fosforilada, inibe fatores de morte neuronal, como a pró-caspase- 9 e Bad, e estimula fatores de transcrição ( $p$-CREB) os quais promovem a transcrição de genes para sobrevivência da célula.

Outro tipo de via que induz a morte celular é a via extrínseca, conhecida por ter receptores de morte. Estes receptores são os receptores de fator de necrose tumoral (TNFR), que inclui receptores TNFR-1 e Fas/CD95, e receptores de fator de necrose tumoral com liberação de ligante (TRAIL) (BERGANTINI et al., 2005).

Os receptores TNF ou Fas e o TRAIL estão localizados na parte citosólica e são estimulados pelos seus devidos ligantes. Quando ativados, formam agregados em trímeros, ligando-se à proteína adaptadora Tradd (Fasassociated death domain), que é encontrada no citoplasma. Esta proteína ligase às caspases intracelulares como, por exemplo, a pró-caspase-8 no caso do receptor Fas, tendo como resultado a formação de um complexo chamado de DISC (Death Inducing Signalling Complex). Este complexo resultará na 
autoclivagem e na ativação das demais caspases (Figura 5), que podem desencadear efeitos, como a interferência na via mitocondrial, ou seguir ativando as demais caspases e provocando a morte celular (THORBUM, 2004; PINKOSKI et al., 1999; PATEL, 2000; SCAFFIDI et al., 1999).

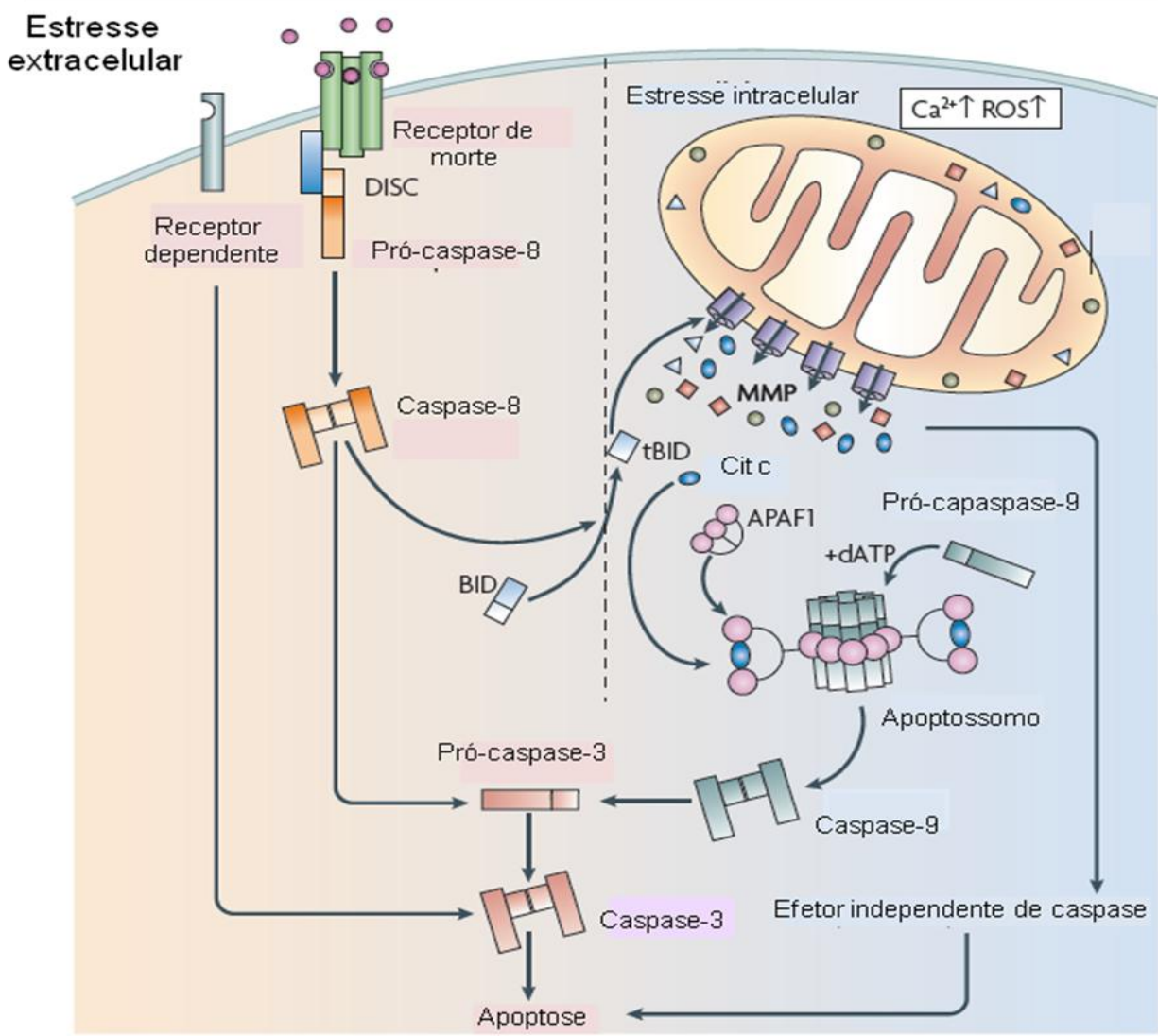

Figura 5. Representação esquemática de duas vias de sinalização de morte celular: intrínseca e extrínseca. Durante a ativação da via intrínseca, ocorre a liberação de proteínas mitocondriais (como por exemplo a Bcl-2, AIF, IAP) formando o apoptossomo, o qual ativa a via das caspases, culminando na morte celular por apoptose. Já na via extrínseca, há a ativação de receptores de morte celular localizados na membrana e do DISC (death-inducing signalling complex), complexo acoplado ao receptor que cliva a pró-caspase-8, culminando na ativação da caspase-3. Além disso, existem receptores localizados na membrana que, quando ativados, estimulam diretamente a caspase-3, culminando com a morte celular (Adaptado e traduzido de GALLUZZI et al., 2009).

Estas vias são algumas das que induzem a morte celular por apoptose. Deve-se também levar em consideração que fatores físicos (irradiação 
ultravioleta, radiação iônica) e químicos (contato com determinadas substâncias) também podem induzir o processo de morte celular.

A tabela 1 a seguir menciona as principais diferenças morfológicas entre apoptose e necrose.

Tabela 1. Principais diferenças morfológicas entre apoptose e necrose (Modificada de ELMORE, 2007).

\begin{tabular}{|c|c|}
\hline APOPTOSE & NECROSE \\
\hline $\begin{array}{c}\text { Ocorre em uma célula ou pequeno } \\
\text { grupo }\end{array}$ & Em células contínuas \\
\hline Diminuição do líquido celular & Aumento do líquido celular \\
\hline Membrana celular intacta & Ruptura da membrana celular \\
\hline $\begin{array}{c}\text { Citoplasma retido em corpos } \\
\text { apoptóticos }\end{array}$ & Extravasamento do citoplasma \\
\hline Não tem reação inflamatória & Reação inflamatória \\
\hline
\end{tabular}

\subsubsection{EXCITOTOXICIDADE}

A excitotoxicidade é mediada pela exacerbação dos efeitos do neurotransmissor excitatório, como o glutamato.

Este processo se inicia com a ativação do receptor de membrana ionotrópico a-amino-3-hidroxi-5-metil-4-isoxazolepropionico (AMPA) pelo glutamato, o qual permite a entrada de íons sódio, levando à despolarização da membrana. A mudança neste potencial leva a ativação das bombas $\mathrm{Na}^{+} / \mathrm{K}^{+}$ATPase e $\mathrm{Na}^{+} / \mathrm{Ca}^{2+}$-ATPase, que trocam íons das células com 0 meio extracelular. Além disso, essa despolarização desloca o átomo de magnésio que bloqueia o receptor $\mathrm{N}$-metil-D-aspartado (NMDA), permitindo a entrada de cálcio para o interior da célula (HARDINGHAM \& BADING, 2003).

Concomitantemente, a ativação do receptor metabotrópico de glutamato promove o aumento dos níveis de 1,4,5-trifosfato de inositol $\left(\mathrm{IP}_{3}\right)$, responsável pela abertura dos canais para cálcio do retículo endoplasmático, liberando seu estoque de cálcio. Outro canal ativado pela despolarização é o canal para 
cálcio voltagem dependente (VDCC), que permite a entrada destes íons na célula. Assim, por meio de vários mecanismos, o glutamato culmina com o aumento de cálcio intracelular (HARDINGHAM \& BADING, 2003).

O cálcio, por sua vez, ativa uma série de proteínas, como a óxido nítrico sintetase, responsável pela formação de NO, um neurotransmissor gasoso que atua como sinalizador celular e que, em excesso, pode desencadear danos celulares pela produção de radicais livres, principalmente quando associado ao oxigênio (WANG \& SCHWARZ, 2008). O cálcio pode ser usado como sinalizador das mudanças fisiológicas ou patológicas de uma célula, pois sua concentração no citosol é normalmente baixa em relação ao encontrado no líquido extracelular e no lúmen do retículo citoplasmático. Existem três tipos de canais de cálcio que podem mediar essa sinalização: VDCC, canais de liberação de cálcio ativados pelo $\mathrm{IP}_{3}$ e receptores de rianodina (ALBERTS et al., 2002).

O IP 3 estimula a liberação de mais cálcio do reticulo endoplasmático, um processo conhecido como liberação de cálcio induzida por cálcio. Contudo, este estímulo é inibido quando a concentração do íon está suficientemente alta. A frequência de oscilação do cálcio reflete a força do estímulo extracelular, podendo tornar a resposta celular dependente de frequência. Mais ainda, encontram-se proteínas de ligação ao cálcio, como por exemplo, a calmodulina, presente no citosol de células encefálicas e da musculatura lisa. Quando a calmodulina é ativada, responde de forma cooperativa ao aumento na concentração do íon, servindo também como uma subunidade reguladora permanente de um complexo enzimático, permitindo sua ligação a várias outras proteínas-alvo na célula, alterando suas atividades, como no caso das 
proteínas quinases que são ativadas pelo cálcio presente no composto da calmodulina (ALBERTS et al., 2002).

Os receptores de rianodina estão relacionados aos processos de aprendizado e memória. Até o momento foram caracterizados três subtipos, sendo que no SNC foi descrito o subtipo RyR3. Estes receptores aumentam a condução dos canais de íons localizados no reticulo endoplasmático, levando ao aumento da permeabilidade de cálcio nos sistemas (KIMLICKA, 2011).

\subsubsection{ESTRESSE OXIDATIVO}

Outro processo que pode desencadear morte celular é o estresse oxidativo, cujo conceito refere-se ao estado em que a produção de agentes oxidantes ultrapassa as capacidades antioxidantes. O sistema antioxidante pode ser dividido em enzimático e não-enzimático. Os principais antioxidantes não enzimáticos são a glutationa, a vitamina $E$, o ascorbato e, entre os enzimáticos, destaca-se a superóxido dismutase (SOD), a catalase, a glutationa peroxidase (HALLIWELL \& GUTTERIDGE, 1999). O estresse oxidativo gera oxidação de constituintes celulares, como lipídeos, proteínas e DNA, levando à morte celular (FLOYD, 1999). Todos os organismos vivos podem sofrer danos por oxidação. De maneira geral, os tecidos nervosos estão mais propensos a estes danos devido a fatores como o alto fluxo de cálcio pelos neurônios, a presença de aminoácidos excitatórios, principalmente o glutamato, além da alta taxa de consumo de oxigênio molecular $\left(\mathrm{O}_{2}\right)$ e pela deficiência nas defesas antioxidantes quando comparado com outros tecidos (MARKESBERY, 1999). 


\subsection{RECEPTORES MUSCARÍNICOS E O SISTEMA NERVOSO}

\section{CENTRAL}

Os receptores colinérgicos estão distribuídos no sistema nervoso periférico e central e são divididos em dois grupos: os receptores muscarínicos e os nicotínicos.

A acetilcolina é um sinalizador celular que age como neurotransmissor e desempenha função autócrina em embriões e adultos. Além disso, no sistema endócrino, age regulando o crescimento, desenvolvimento e morte celular, dependendo da ação e do local (EGLEN, 2006).

A ação metabotrópica da acetilcolina está relacionada aos receptores muscarínicos, que são divididos em cinco subtipos: $M_{1}, M_{2}, M_{3}, M_{4}, M_{5}$ (CAULFIELD \& BIRDSALLI, 1998). Estes receptores são acoplados à diferentes subtipos da proteína $\mathrm{G}$, estimulando vias intracelulares distintas. Os receptores $M_{1}, M_{3}$ e $M_{5}$ são acoplados a proteína $G q$, que, ao ser ativada, se divide em duas subunidades, a subunidade $\beta / \gamma$, que fica acoplada ao receptor, e a subunidade a. Quando estão separadas indica que o receptor está ativado, sendo que a subunidade a mobiliza fosfatidilinositol da membrana celular gerando $\mathrm{IP}_{3}$ e 1,2-diacilglicerol. $\mathrm{O} \mathrm{IP}_{3}$ libera os estoques de cálcio do retículo endoplasmático, com consequente aumento do cálcio intracelular. Tal aumento sinaliza que as reservas estão sendo utilizadas, o que leva à abertura dos canais transmembrânicos para a entrada de mais cálcio na célula. Já o diacilglicerol ativa a proteína quinase C (PKC), importante para o controle do crescimento e diferenciação celular (SCHELL \& IRVINE, 2006).

Os subtipos $M_{2}$ e $M_{4}$ são acoplados à proteína $G i$, ou seja, quando ativados exercem ação inibitória nas células. Isto acontece porque a proteína 
Gi diminui a formação de AMP cíclico e a ativação de proteína quinase A (PKA). O AMPc está envolvido na abertura dos canais de sódio na membrana plasmática, provocando a despolarização e a iniciação dos impulsos nervosos. Além disso, a PKA exerce sua ação no núcleo celular fosforilando fatores de transcrição como o CREB, que recruta coativadores e fatores de transcrição de genes relacionados ao $\mathrm{AMPc}$. A regulação da expressão destes genes é importante para o controle da proliferação e diferenciação das células (NEVES et al., 2002; HOFMANN, 2005).

No sistema nervoso central, os receptores muscarínicos estão presentes em diferentes regiões. Os receptores muscarínicos do subtipo $M_{1}$ estão localizados principalmente no córtex cerebral, hipocampo e estriado e estão relacionados aos processos de aprendizado e memória. O subtipo $M_{2}$ está localizado no sistema nervoso central, encontrado nos neurônios da área ventral do tegmento mesencefálico e do córtex frontal, permanecendo preferencialmente nas regiões em que são sintetizados, como ocorre em muitos dendritos. No caso do caudado putâmen, a ação do receptor é inibitória nos heterorreceptores dopaminérgicos, o que indica que o bloqueio seletivo da ação deste receptor pode apresentar uma ação terapêutica para doenças em que há uma grande liberação de dopamina (EGLEN, 2006).

O subtipo $\mathrm{M}_{3}$ é amplamente distribuído no SNC, no entanto, os níveis são significativamente mais baixos em relação aos outros subtipos de receptores. O receptor muscarínico subtipo $\mathrm{M}_{3}$ foi classicamente identificado mediando à contração dos músculos do sistema respiratório, gastrointestinal e do trato genitourinário. De acordo com a revisão feita por EHLERT (2003), os 
subtipos $M_{2}$ e $M_{3}$ atuam juntamente para controlar a motilidade, que varia de acordo com cada tecido.

O receptor muscarínico subtipo $\mathrm{M}_{4}$ também é encontrado no $\mathrm{SNC}$, mais especificamente no estriado e nas projeções dos neurônios desta região. Possuem ação nociceptiva por meio da medula espinal (FELDER et al., 2000; OKI et al., 2005; DUTTAROY et al., 2002).

Por fim, o subtipo $M_{5}$, o único expresso em neurônios que contém dopamina na parte compacta da substância negra, uma estrutura proveniente das inervações dopaminérgicas do estriado. A ativação deste receptor estimula também a liberação de dopamina, envolvendo outros receptores, como o subtipo $M_{4}$. A expressão do subtipo $M_{5}$ varia de acordo com as inervações dopaminérgicas, como ocorre na área ventral do tegmento mesencefálico e outras áreas límbicas. (BURSTEIN et al., 1998)

\subsection{EFEITO DA COCAÍNA/CRACK NA MORTE NEURONAL}

Os efeitos neurotóxicos da cocaína têm sido amplamente discutidos. A cocaína é citotóxica em diversos tipos de linhagens celulares do SNC. Foi demonstrada indução de apoptose pela cocaína em neurônios corticais de ratos (NASSOGNE et al., 1997; CUNHA-OLIVEIRA et al., 2010). O mesmo efeito foi descrito em células dopaminérgicas PC12 (LEPSCH et al., 2003; IMAN et al., 2005; CUNHA-OLIVEIRA et al., 2008), além da inibição de crescimento de neuritos (ZACHOR et al., 2003). Diversas evidências também apontam para uma possível ação da cocaína no sistema redox da célula, principalmente no que diz respeito ao estresse oxidativo. Estudos desenvolvidos por FANTEL et al. (2002) e SHARAN et al. (2003) destacaram a 
relação da cocaína com o estresse oxidativo, indicando uma possível via para a neurotoxicidade. Porém, no que diz respeito à neurotoxicidade da AEME, pouco se sabe a respeito.

Neste sentido, estudo realizado por GARCIA et al. 2012 avaliou os efeitos neurotóxicos da cocaína e da AEME em cultura primária de hipocampo. Este tipo de cultura foi escolhida em função da possível ação muscarínica da AEME e das disfunções cognitivas relatadas em usuários de crack (CUNHA et al., 2004).

Esta cultura de hipocampo é composta por neurônios principais excitatórios e interneurônios inibitórios (ALKONDON \& ALBUQUERQUE, 2002). A diferença dos tipos de neurônios ocorre devido à constituição do hipocampo que é composto pelo giro dentado (GD), que inclui a fascia dentata e o hilus; e pelo cornu ammonis (CA) composto pelas regiões CA1, CA2 e CA3. Nestas regiões encontram-se principalmente dois tipos celulares, as piramidais e as granulares, dependendo das sub-regiões (AMARAL, 1978; AMARAL \& LAVENEX, 2007). A cultura primária de hipocampo realizada a partir de hipocampo de fetos de ratos é caracterizada pela predominância de células piramidais uma vez que as células granulares ainda não estão presentes no período pré-natal (ARACAVA et al., 1987).

GARCIA et al. 2012 relataram que tanto a cocaína quanto a AEME induziram morte neuronal, entretanto, a potência da AEME foi maior do que a da cocaína, uma vez que concentrações menores de AEME provocaram redução mais acentuada do metabolismo mitocondrial. Mais ainda, quando a cocaína e a AEME foram associadas em concentrações equipotentes, houve um efeito aditivo na diminuição da viabilidade celular (Figura 6). Por outro lado, 
quando foi avaliada a integridade da membrana plasmática por meio da liberação da enzima lactato desidrogenase (LDH), somente a cocaína provocou aumento de sua liberação (Figura 7), sugerindo mecanismos neurotóxicos distintos entre cocaína e AEME.

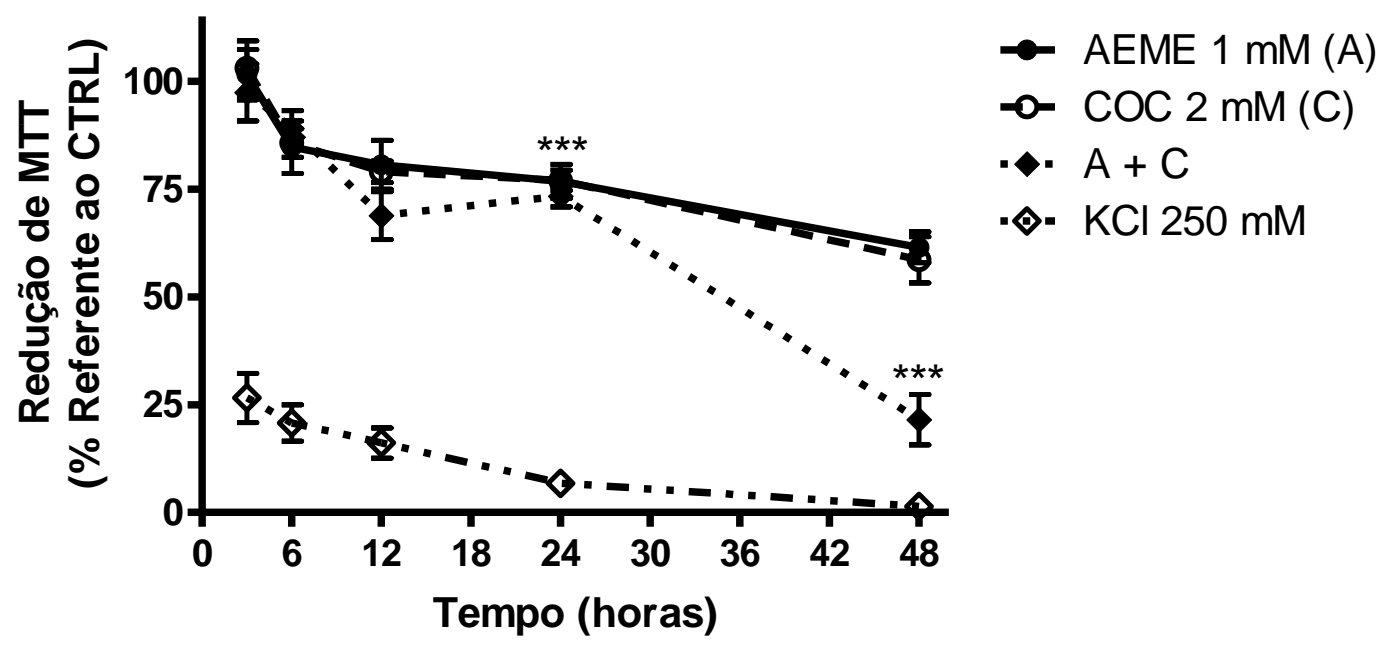

Figura 6. Curva de MTT $(n=5)$ após exposição de 3; 6; 12; 24 e 48 horas a concentrações equipotentes de $A E M E$ e $C O C$ e a associação das mesmas $(A+C)$. ${ }^{* *} p<0,001$ em relação à COC e à AEME (ANOVA e comparação múltipla de Newman-Keuls) (GARCIA et al., 2012). 
A

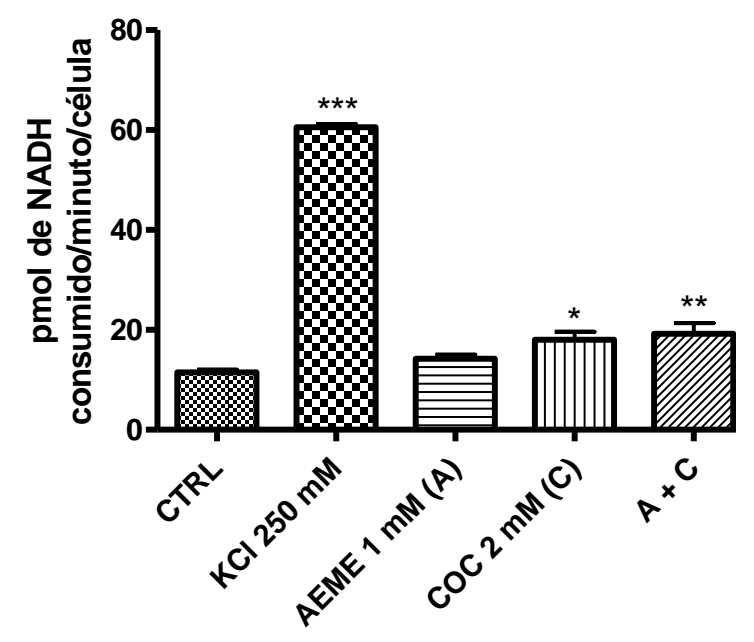

B

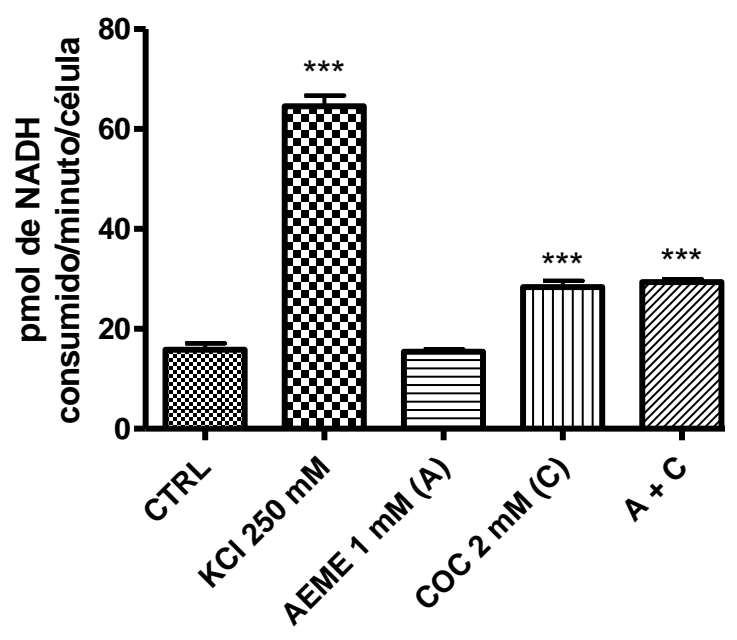

Figura 7. Ensaio de $\operatorname{LDH}(n=5)$ após: A) 24 horas de exposição; B) 48 horas de exposição. $\mathrm{CTRL}=$ controle; $\mathrm{KCl}=$ cloreto de potássio; $\mathrm{COC}=$ cocaína; $\mathrm{AEME}=$ metilecgonidina; $\mathrm{A}+\mathrm{C}=$ associação entre metilecgonidina $1 \mathrm{mM}$ e cocaína $2 \mathrm{mM} .{ }^{*} \mathrm{p}<0,05 ;{ }^{* *} \mathrm{p}<0,01 \mathrm{e}{ }^{* * *} \mathrm{p}<0,001 \mathrm{em}$ relação ao CTRL (ANOVA e comparação múltipla de Newman-Keuls) (GARCIA et al., 2012).

Com base no exposto acima, a AEME parece não ser somente um marcador biológico do uso de crack, e sim ser dotado de uma ação neurotóxica. Portanto, torna-se importante a investigação dos mecanismos subjacentes à neurotoxicidade da AEME.

É consenso que o crack apresenta maior potencial de abuso quando comparado às demais formas de administração de cocaína. Como a inalação da AEME é o que diferencia o crack das outras vias de administração da cocaína e que resultados prévios de nosso grupo mostraram uma ação neurotóxica da AEME em cultura primária de hipocampo, é possível que esta ação participe do efeito devastador do crack. 
2. OBJETIVOS 
Estudar os mecanismos envolvidos no processo de morte neuronal induzida pela AEME, cocaína e associação (AEME 1mM /cocaína 2 mM), em cultura primária de hipocampo. 


\section{MATERIAIS E MÉTODOS}




\subsection{SÍNTESE DA AEME}

A cocaína utilizada na síntese de AEME foi gentilmente cedida pelo Núcleo de Exames de Entorpecentes do Instituto de Criminalística de São Paulo para fins de pesquisa do Laboratório de Análises Toxicológicas do Departamento de Análises Clínicas e Toxicológicas da Faculdade de Ciências Farmacêuticas da USP.

Uma solução de cloridrato de cocaína foi refluxada em ácido clorídrico concentrado por 24 horas. Após o resfriamento à temperatura ambiente, a mistura foi diluída com água e extraída com éter dietílico para remoção do ácido benzóico. A fase aquosa foi evaporada sob vácuo até a secura. O sólido branco obtido foi então seco sob vácuo à $100{ }^{\circ} \mathrm{C}$ por 24 horas (ZHANG et al., 1997). O resíduo seco foi dissolvido em metanol absoluto e adicionou-se ácido sulfúrico concentrado. A mistura foi aquecida e refluxada por aproximadamente 24 horas. Após este período, removeu-se o álcool sob vácuo e dissolveu-se o resíduo em uma pequena quantidade de água. A solução aquosa foi saturada com carbonato de potássio, filtrada e extraída com éter. As frações orgânicas foram combinadas, secas com sulfato de magnésio, filtradas e evaporadas sob vácuo, resultando em um líquido amarelado. O produto foi purificado por destilação a pressão reduzida e identificado por espectrometria de massas e RMN- ${ }^{1} \mathrm{H}$ (KLINE et al., 1989). A pureza da AEME foi verificada como sendo maior que $95 \%$.

\subsection{DELINEAMENTO EXPERIMENTAL}


O estudo foi realizado utilizando-se cultura embrionária hipocampal de ratos (THOMPSON et al., 2002; THOMPSON et al., 2004; DEL OLMO et al., 2006) conforme protocolo padronizado por nosso grupo.

Os ensaios foram realizados em quatro grupos experimentais: controle, AEME, cocaína e associação (AEME $1 \mathrm{mM}$ /cocaína $2 \mathrm{mM}$ ). As concentrações foram usadas baseado no trabalho de GARCIA et al. 2012, sendo utilizada as que induziam morte neuronal através de experimento de MTT. Assim, foi possível caracterizar qual a contribuição da AEME no caso de uma incubação com as duas substâncias concomitantemente.

\subsection{CULTURA DE CÉLULAS}

\subsubsection{ANIMAIS}

Foram utilizadas ratas Wistar prenhes mantidas no Biotério do Laboratório de Farmacologia, fornecidas pelo Biotério Central do Instituto Butantan. Durante o período em que permaneceram no biotério os animais tiveram acesso livre a água e a comida (ração para roedores - Nuvilab $C R 1^{\circledR}$ ), temperatura controlada $\left(21 \pm 2^{\circ} \mathrm{C}\right)$ e ciclo claro-escuro de doze horas (luz ligada às $7 \mathrm{~h} 00)$. Os animais foram mantidos em caixas de polietileno $(16 \mathrm{~cm}$ de altura, $30 \mathrm{~cm}$ de largura e $38 \mathrm{~cm}$ de comprimento) forradas com maravalha, contendo apenas 2 fêmeas por caixa. Todos os experimentos foram realizados no período claro $(8 \mathrm{~h} 00-12 \mathrm{~h} 00)$.

\subsubsection{CULTURA DE NEURÔNIOS HIPOCAMPAIS}

O método de estabelecimento da cultura foi baseado nos trabalhos de BANKER et al. (1977), HUETTNER et al. (1986) e JAHR et al. (1989) e é 
composta por $97 \%$ de neurônios e $3 \%$ de glia, conforme caracterizado por GARCIA et al. (2012).

A rata prenhe foi anestesiada com pentobarbital $(45 \mathrm{mg} / \mathrm{kg})$ e foi realizada uma cesariana para retirada dos fetos. Os fetos foram decapitados com tesoura, a caixa craniana foi aberta e os hemisférios encefálicos separados. Com auxilio de uma lupa, os hipocampos foram identificados e dissecados. Para manutenção do tecido a estrutura foi mantida em solução de meio neurobasal estéril. O tecido foi manuseado sobre um papel de filtro umedecido em solução de Hanks, sobre uma placa de Petri e gelo por baixo.

\subsubsection{DISSOCIAÇÃO DE CÉLULAS HIPOCAMPAIS EMBRIONÁRIAS}

As células hipocampais isoladas foram obtidas utilizando-se o método de digestão proteolítica com tripsina (BANKER et al., 1977; HUETTNER et al., 1986; JAHR et al., 1989).

Os hipocampos depois de isolados foram colocados em meio de cultura Neurobasal sem suplemento B27 (Gibco), acrescido de estreptomicina e penicilina. Em seguida, sob fluxo laminar, os hipocampos foram transferidos para uma placa de Petri, onde foram lavados com solução de Hanks filtrada e picotados de modo a obter pequenos pedaços de tecido. O material foi transferido, com auxilio de uma pipeta Pasteur, para um erlenmeyer (25 mL) contendo uma solução de tripsina, cujo $\mathrm{pH}$ foi acertado para 7,4 com carbogênio. O frasco contendo os fragmentos de hipocampo foi colocado em banho com agitação plana a $37^{\circ} \mathrm{C}$, permanecendo por 10 minutos. Em seguida, a solução resultante da digestão com tripsina foi transferida para um tubo Falcon de $15 \mathrm{~mL}$ com $3 \mathrm{~mL}$ de solução de descanso $(2700 \mu \mathrm{L}$ de EBSS +150 
$\mu \mathrm{L}$ de DNAse, ressuspendido em $500 \mu \mathrm{L}$ de EBBS $+300 \mu \mathrm{L}$ de soro fetal bovino $10 \%$ ). O tubo foi centrifugado a $1258 \mathrm{rpm}(300 \mathrm{~g})$ por 2 minutos a $20{ }^{\circ} \mathrm{C}$. O sobrenadante foi desprezado e ressuspendido em $2 \mathrm{~mL}$ da mesma solução de descanso. Posteriormente, o tecido foi disperso com pipetas Pasteur de diversos diâmetros, cerca de 20 vezes. O frasco foi centrifugado a $1258 \mathrm{rpm}$ (300g) por 5 minutos a $20 \stackrel{\circ}{ } \mathrm{C}$, após este período o sobrenadante foi desprezado e o resultante ressuspenso em $1 \mathrm{~mL}$ de meio pronto (Neurobasal com suplemento B27 (Gibco), glutamina, glutamato e antibiótico).

Uma alíquota de $10 \mu \mathrm{L}$ foi retirada e corada com azul de Tripan (concentração de 1\% em PBS) para avaliar a viabilidade celular e o número de células obtidas. As células foram contadas em câmara de Neubauer e, em função do número de células obtidas, foi realizada diluição com meio Neurobasal de modo a obter o número de células $/ \mathrm{mL}$ proporcional para 0 diâmetro dos poços das placas. Os poços foram pré-tratados com poli-L-lisina (PLL), para melhor aderência dos neurônios à mesma. As placas com as células foram incubadas em estufa com $5 \%$ de $\mathrm{CO}_{2}$. Após 48 horas, metade do meio de cultura foi substituído por um meio novo (Neurobasal com suplemento B27 (Gibco), glutamina, glutamato e antibiótico).

Para o preparo das placas com PLL, adicionou-se a quantidade suficiente da solução de PLL para cobrir o fundo do poço de uma placa estéril. Após cerca de 30 minutos, para certificar o contato do polímero com a placa, o excedente foi removido e aguardou-se até que a placa estivesse totalmente seca. A placa foi embrulhada em papel alumínio e mantida no refrigerador. Todas as etapas foram realizadas sob fluxo laminar. 


\subsection{PARTICIPAÇÃO DOS RECEPTORES COLINÉRGICOS}

\section{MUSCARÍNICOS NA AÇÃo DA AEME.}

A participação dos receptores muscarínicos na alteração da viabilidade celular provocada pela AEME, cocaína e associação (AEME $1 \mathrm{mM}$ /cocaína $2 \mathrm{mM}$ ), foi avaliada na ausência e na presença de atropina, um antagonista inespecífico de receptores colinérgicos muscarínicos. Neste teste o $\mathrm{KCl}$ foi utilizado como controle positivo para o experimento.

Foi utilizado o método de MTT (brometo de 3-(4,5-dimetiltiazolil-2)-2,5difeniltetrazólio, ou brometo de tetrazólio) na avaliação da viabilidade celular. Este sal avalia a atividade metabólica das células viáveis (MOSMANN, 1983; LIU et al., 1997). Na presença da enzima succinato desidrogenase mitocondrial, esta enzima está ativa quando o metabolismo da cadeia respiratória está intacto, o MTT é reduzido em formazan. O formazan é, posteriormente, solubilizado em solvente orgânico e quantificado espectrofotometricamente em comprimento de onda de 570nm.

As células foram plaqueadas em placas de 96 poços, com uma densidade de $2 \times 10^{4}$ células/poço. Após sete dias de crescimento, as células foram incubadas com as substâncias de interesse. As concentrações de cocaína utilizadas foram $10^{-2}, 10^{-1}, 1$ e $2 \mathrm{mM}$, enquanto que as concentrações de AEME foram $10^{-3}, 10^{-2}, 10^{-1}$ e $1 \mathrm{mM}$. As concentrações utilizadas na associação (AEME $1 \mathrm{mM} /$ cocaína $2 \mathrm{mM}$ ) foram as mesmas utilizadas por GARCIA et al. 2009. Todas as concentrações foram testadas na ausência e na presença de atropina nas concentrações de $1 \mu \mathrm{M}$ e $50 \mu \mathrm{M}$, concentrações baseadas nos trabalhos que utilizaram atropina em cultura celular e neste 
trabalhos foi observado que nestas concentrações a atropina foi capaz de proteger as células (MAGGl et al., 2001; KENDER et al., 2008).

Todas as incubações foram realizadas por 24 horas. Após este período, todo o meio de cultura foi trocado e substituído $(100 \mu \mathrm{L})$ por um novo meio contendo o sal de MTT ( $5 \mathrm{mg} / \mathrm{mL}$ em PBS). As células foram então incubadas por 3 horas em estufa a $37^{\circ} \mathrm{C}$ com $5 \% \mathrm{CO}_{2}$. Posteriormente, foram adicionados $100 \mu \mathrm{L}$ de dimetilsulfóxido (DMSO) em todos os poços e a placa ficou sob agitação por 30 minutos. Posteriormente, foi feita a leitura e os resultados foram expressos em porcentagem relativos ao grupo controle (ABE et al., 1999; IOUDINA et al., 2004).

\subsection{DETERMINAÇÃO DA FORMAÇÃO DE FOSFATOS DE INOSITOL} (MONO-, BI- E TRIFOSFATO DE INOSITOL) EM HIPOCAMPO.

Para avaliar a formação de fosfato de inositol nas células foi utilizado o método de ABDALLA et al. (2000), com algumas modificações.

As células foram cultivadas como descrito anteriormente sendo que em cada poço foi cultivado $1 \times 10^{6}$ células. Foi adicionado $[3 \mathrm{H}]$ mio-inositol e $\mathrm{LiCl}$ $10 \mathrm{mM}$, as células ficaram por 30 minutos em banho-maria a $37^{\circ} \mathrm{C}$ sob agitação. Após esse período, as células foram incubadas na ausência (para determinação do nível basal de fosfatos de inositol) e na presença de carbacol e/ou da substância de interesse, por 5 minutos. A seguir, as células foram retiradas utilizando solução básica ( $\mathrm{NaOH}$ a 0,1M) (ABDALLA et al., 2000).

Para a extração dos fosfatos de inositol (mono-, bi- e trifosfato de inositol) foi utilizado o método de FOX et al. (1985), com algumas modificações. As células foram adicionadas em uma solução contendo 
metanol:clorofórmio $(2: 1 \mathrm{v} / \mathrm{v})$, em seguida foram centrifugadas a $1000 \mathrm{~g}$ por 5 minutos, para separação das fases orgânica (fosfolipídeos) e aquosa (fosfatidilinositóis).

Os fosfatos de inositol foram separados segundo o método descrito por ASCOLI et al. (1989), com algumas modificações. Assim, a fase aquosa contendo os fosfatidilinositóis foi neutralizada com solução ácida $(\mathrm{HCl}$ a $0,1 \mathrm{M})$ e foi incubada com $1 \mathrm{~mL}$ de resina de troca iônica (Dowex AG1-X8, 200-400 mesh) por 30 minutos, a temperatura ambiente e sob agitação. Decorrido este período, a amostra foi centrifugada a $1000 \mathrm{~g}\left(5\right.$ minutos, $\left.4^{\circ} \mathrm{C}\right)$ e o sobrenadante foi descartado. A resina foi tratada, sequencialmente, com $2 \mathrm{~mL}$ de mio-inositol (10 mM) e com $2 \mathrm{~mL}$ de uma solução de borato de sódio 5 $\mathrm{mM} /$ formiato de sódio $60 \mathrm{mM}$ para a eluição de mio-inositol livre (inespecífico) e de glicerofosfo-inositol, respectivamente. Em seguida, a resina foi incubada com $2 \mathrm{~mL}$ de uma solução de ácido fórmico $0,1 \mathrm{M}$ /formiato de amônio $1 \mathrm{M}$ (30 minutos, temperatura ambiente) e sob agitação. Após este período, a resina foi centrifugada ( $1.000 \mathrm{~g}, 5$ minutos, $\left.4^{\circ} \mathrm{C}\right)$ e os fosfatos de inositol foram diluídos. Foi adicionado $1 \mathrm{~mL}$ do sobrenadante em frascos contendo $5 \mathrm{~mL}$ de líquido de cintilação e a radioatividade foi determinada em contador $\beta$ (LS 6500 IC, Beckman). O nível basal de fosfatos de inositol (dpm/célula) foi determinado e os demais valores obtidos foram expressos em relação ao basal.

\subsection{MEDIDA DO CÁLCIO INTRACELULAR EM CULTURA DE} NEURÔNIOS HIPOCAMPAIS POR MICROSCOPIA CONFOCAL

Para avaliar a presença do cálcio intracelular, foi utilizado o indicador $\mathrm{Ca}^{2+}$ Flúor-4-AM (Fluo-4) (Molecular Probe) (BAN et al., 2006), pois ao entrar 
em contato com o cálcio, emite fluorescência, a qual é quantificada por meio de microscópio confocal e é diretamente proporcional à concentração de cálcio intracelular

As células foram cultivadas em placa de 24 poços, como descrito anteriormente e no sétimo dia foi realizado o experimento, após tripsinização das células. As células foram incubadas por uma hora com o fluo-4 em meio de cultura sem suplementos. Durante o período de marcação das células, as placas utilizadas para leitura no microscópio confocal foram tratadas com PLL, para aderência das células, a qual foi colocada no fundo da placa por 30 minutos. Após este período, a PLL foi retirada e as placas ficaram 10 minutos para secagem. Posteriormente, as células foram centrifugadas a $1258 \mathrm{rpm}$ (300g) por 5 minutos a $20 \stackrel{\circ}{ } \mathrm{C}$ e lavadas com meio de cultura sem cálcio. Foram feitas duas lavagens para a retirada do excesso do fluor-4. Posteriormente, as células devidamente carregadas com o fluoróforo foram visualizadas em um microscópio confocal (Zeiss LSM 510 - Meta). As imagens digitalizadas foram calculadas por meio da diferença encontrada em relação ao controle usando o software de processamento de imagem Origin 5.

Para avaliar os efeitos da AEME, cocaína e da associação (AEME $1 \mathrm{mM} /$ cocaína $2 \mathrm{mM}$ ) sobre a concentração de $\mathrm{Ca}^{2+}$ intracelular, as células foram avaliadas por 2 minutos e trinta segundos. Após 2 segundos sem estímulo, a substância de interesse foi adicionada e as células foram avaliadas por um minuto e meio. Após este período, colocou-se $\mathrm{KCl}$ para que houvesse morte celular, isto ocorre devido a despolarização da membrana induzindo a mudança no potencial e diferença na concentração de íons intra e extracelular, induzindo a célula a morte, as células foram avaliadas por 5 segundos. 


\subsection{ANÁLISE DE INTEGRIDADE DA MEMBRANA}

Para análise da integridade da membrana celular, foi utilizado o fluoróforo iodeto de propídio ( $\mathrm{Pl}$ ) para marcar as células que estavam com a membrana rompida, uma vez que este marcador é altamente hidrossolúvel e não tem a capacidade de penetrar nas células com membranas íntegras. A fluorescência foi comparada entre as células sem tratamento (controle) com as tratadas com AEME $10^{-1}$ e $1 \mathrm{mM}$, cocaína 1 e $2 \mathrm{mM}$ e associação (AEME $1 \mathrm{mM}$ /cocaína 2mM). Para este experimento os neurônios foram incubados por 12 e 24 horas.

Após a incubação, os neurônios $\left(1 \times 10^{6}\right.$ células/poço) foram retirados da placa por tripsinização, sendo que foi coletado $300 \mu \mathrm{L}$ de células e incubado 30 $\mu \mathrm{L}$ de solução contendo PI. As amostras foram analisadas imediatamente após a incubação com PI, para que este não se torne tóxico às células. Os neurônios foram analisados por citometria de fluxo (Becton Dickinson, USA) e a fluorescência foi medida utilizando o canal FL2 (laranja-vermelho fluorescência = 585nm de excitação e $642 \mathrm{~nm}$ de emissão). Foram analisadas 10 milhões de células por experimento. Para a análise da fluorescência do PI foi utilizado o software Cell Quest (Becton Dickinson).

\subsection{ANÁLISE DA FRAGMENTAÇÃO DE DNA POR CITOMETRIA DE}

\section{FLUXO}

A quantificação de DNA fragmentado é um indicativo de apoptose. Para a análise, foi usado o $\mathrm{PI}$ como fluorescente, citrato e triton como detergente. $\mathrm{O}$ uso do detergente permite que o PI penetre pela membrana, já que neste caso, não há necessidade de mantê-la íntegra. 
O PI, ao entrar na célula, se intercala nas bases do DNA e, quando o DNA está íntegro, há maior fluorescência, pois apresenta uma estrutura maior e, desta forma, o PI reage com mais bases. Em casos de fragmentação do DNA, detecta-se menor fluorescência, pois o PI se intercala em pequenos fragmentos.

Os neurônios ( $1 \times 10^{6}$ células/poço) foram incubados com AEME $10^{-1}$ e 1 mM, cocaína 1 e 2 mM e associação (AEME 1 mM/cocaína 2 mM), por 12 e 24 horas. Após a remoção, por tripsinização, as células foram centrifugadas a $500 \mathrm{~g}$ por 5 minutos e o pellet foi incubado com a solução contendo $\mathrm{PI}$ e os detergentes por 2 horas em temperatura ambiente. As células foram analisadas por citometria de fluxo (Becton Dickinson, USA) e a fluorescência foi medida utilizando o canal FL2 (laranja-vermelho fluorescência $=585 \mathrm{~nm}$ de excitação e $642 \mathrm{~nm}$ de emissão). Foram analisadas 10 milhões de células por experimento. Para a análise da fluorescência do PI foi utilizado o software Cell Quest (Becton Dickinson).

\subsection{QUANTIFICAÇÃO DAS PROTEÍNAS BCL-2 E BAX}

A expressão das proteínas apoptóticas Bcl-2 e Bax foram avaliadas pela técnica de Western blot. As células foram incubadas com AEME $10^{-1}$ e $1 \mathrm{mM}$, cocaína 1 e $2 \mathrm{mM}$ e associação (AEME $1 \mathrm{mM}$ /cocaína $2 \mathrm{mM}$ ), neste caso foram cultivadas $5 \times 10^{5}$ célula por poço. As células foram retiradas do poço por tripsinização e foram homogeneizadas com tampão Tris- $\mathrm{HCl} 50 \mathrm{mM}, \mathrm{pH} 7,4$ acrescido de $1 \mathrm{mM}$ de PMSF, leupeptina $10 \mu \mathrm{g} / \mathrm{mL}, 1 \mathrm{mM}$ de inibidor de protease na diluição 1:10 e Triton (detergente capaz de lisar a membrana 
celular). Após este processo as amostras foram centrifugadas durante 5 minutos a $1000 \mathrm{~g}$ a $4^{\circ} \mathrm{C}$.

Todas as amostras foram ajustadas para a mesma concentração proteica $(20 \mu \mathrm{g})$ (quantificada pelo método de BRADFORD, 1976)com tampão Tris-HCl 50 mM e, em seguida, foi acrescentado tampão de Laemmli $(0,0625 \mathrm{M}$ de Tris- $\mathrm{HCl}$, pH 6,8 contendo $2 \%$ de SDS, $10 \%$ de glicerol, $0,001 \%$ de azul de bromofenol e $5 \%$ de 2-mercaptoetanol). As amostras foram aquecidas a $99^{\circ} \mathrm{C}$ por 5 minutos e centrifugadas a $10000 \mathrm{~g}$ por 1 minuto. As proteínas foram então separadas por eletroforese em gel de poliacrilamida 15\% contendo lauril sulfato de sódio a $0,1 \%$ (SDS - PAGE) conforme originalmente descrito por Laemmli (1970).

Para a separação eletroforética das proteínas, foi utilizado tampão composto por $25 \mathrm{mM}$ de Tris-HCl, $192 \mathrm{mM}$ de glicina e 0,1\% de SDS pH 8,3 e voltagem de $120 \mathrm{~V}$. Posteriormente, as bandas proteicas foram transferidas eletroforeticamente por meio de sistema submerso para membrana de nitrocelulose (100 V) durante 1 hora. A composição do tampão empregado para a transferência eletroforética de proteínas para a membrana de nitrocelulose foi composto por $25 \mathrm{mM}$ de Tris- $\mathrm{HCl}, 192 \mathrm{mM}$ de glicina, 0,1\% de SDS e 18\% de etanol absoluto. Para comprovar a eficiência da transferência, as membranas foram coradas com solução de vermelho de Ponceau $(0,1 \%$ em ácido acético a $5 \%$ ), e lavadas rapidamente para retirada do excesso de corante com tampão TBS-t (20 mM de Tris- $\mathrm{HCl}, 137 \mathrm{mM}$ de $\mathrm{NaCl} \mathrm{pH} \mathrm{7,4,} \mathrm{contendo} \mathrm{0,1 \%} \mathrm{de} \mathrm{Tween-}$ 20).

As membranas foram incubadas com leite desnatado Molico (Nestlé) 5\%, em TBS-t, por 40 minutos sob agitação para que os sítios inespecíficos de 
ligação do anticorpo primário à membrana fossem bloqueados. A seguir, as membranas foram incubadas, overnight a $8^{\circ} \mathrm{C}$, com anticorpos primários específicos - Bcl-2 (monoclonal de coelho, Cell Signaling, EUA) 1:1000 diluídos em $5 \%$ de BSA em tampão TBS-t.

Após o término da incubação, as membranas foram lavadas com tampão TBS-t (3 vezes durante 7 minutos) e incubadas com anticorpos secundários conjugados a enzimas - anticorpo policlonal de coelho (1:2000) - durante 1 horas em temperatura ambiente e sob agitação. As membranas foram submetidas novamente a uma nova série de lavagens com TBS-t e as bandas imunorreativas foram reveladas por incubação com substratos específicos para as enzimas conjugados aos anticorpos secundários, cujas reações envolvem emissão de quimioluminescência.

As bandas foram detectadas por reagente de detecção ECL plus Western Blotting (GE Healthcare Bio-Science UK Limited, Little Shalfont, Buckinghamshire, UK) e exposta em filme fotográfico. Os filmes foram digitalizados em impressora HP Photosmart C4280 e as intensidades das bandas imunorreativas foram comparadas por análise densitométrica pelo programa ImageJ e expressa em porcentagem.

A seguir, as membranas foram lavadas com TBS-t e incubadas, overnight a $8^{\circ} \mathrm{C}$, com anticorpos primários da Bax (monoclonal de coelho, Cell Signaling, EUA) 1:1000 - diluídos em tampão TBS-t a 5\% de BSA.

Após incubação, as membranas foram lavadas (3 vezes durante 7 minutos) com tampão TBS-t e incubadas com anticorpo secundário anticorpo policlonal de coelho (1:2000) Bio Rad durante 1 hora. As membranas foram 
submetidas novamente a uma nova série de lavagens com TBS-t, e as bandas imunorreativas foram reveladas por quimioluminescência.

As membranas foram neutralizadas com água oxigenada, na diluição de 1:1 em água destilada. Foi bloqueada novamente em leite Molico 5\% em TBS-t por 30 minutos. Após este procedimento as membranas foram incubadas com anticorpo primário da GAPDH (gliceraldeido-3-fosfato deidrogenase), que é um gene constitutivo, que não se modifica com o tratamento utilizado e nem com o tipo celular. Foi utilizado o anticorpo monoclonal de rato (Santa Cruz) na diluição de 1:16000 overnight a $8^{\circ} \mathrm{C}$.

Após este período as membranas foram lavadas (3 vezes durante 7 minutos) com tampão TBS-t e incubadas com anticorpo secundário policlonal de rato Bio Rad (1:2000) durante 1 hora. As membranas foram lavadas com TBS-t, e as bandas imunorreativas foram reveladas por quimioluminescência.

O peso molecular das bandas foi calculado a partir das mobilidades relativas de proteínas marcadoras de peso molecular (faixa de 7 a 195 kDa; Bio Rad, EUA).

\subsection{ATIVIDADE DA CASPASE-3}

A atividade da caspase-3 foi realizada medindo-se a fluorescência gerada a partir da clivagem do substrato Z-DEVD-AMC, que libera aminometilcoumarina (AMC).

As células foram cultivadas em placas de 24 poços, sendo que a quantidade de proteína para realizar o protocolo foi de $20 \mu \mathrm{g}$. A dosagem de proteína foi realizada por meio do método de BRADFORD (1976). As células foram lisadas em tampão proteolítico contendo ditiotreitol (DTT) (10mM), PMSF 
$(200 \mathrm{mM})$, aprotinina $(10 \mathrm{mg} / \mathrm{mL})$ e $3-[(3$ colamidopropil) dimetillamonio]-1propanosulfanato hidratado (CHAPS) $(0,1 \%)$. As amostras foram colocadas em placas de 96 poços e o volume do poço foi completado $(200 \mu \mathrm{L})$ com tampão contendo DTT $(10 \mathrm{mM})$, PMSF $(200 \mathrm{mM})$ e aprotinina $(10 \mathrm{mg} / \mathrm{mL})$. Momentos antes da leitura, o substrato foi adicionado para reagir com a amostra e a placa foi lida no fluorímetro. A leitura foi feita por 30 minutos com intervalo de 5 minutos, com comprimento de onda excitação de 400 nm e de emissão entre $480-520 \mathrm{~nm}$.

O coeficiente angular da reta foi usado para determinar a variação na fluorescência ao longo do tempo para cada amostra. 
4. ANÁLISE ESTATÍSTICA 
Os resultados foram comparados pelo teste de variância (ANOVA), seguido do teste Student-Newman-Keuls, sendo que as diferenças foram consideradas significativas para o valor $p<0,05$. Os valores numéricos foram representados na forma de média \pm erro padrão da média. 
5. RESULTADOS 


\subsection{ENVOLVIMENTO COM RECEPTOR COLINÉRGICO}

\section{MUSCARÍNICO}

A Figura 8 mostra os resultados de viabilidade celular (MTT) após 24 horas de incubação. Houve morte neuronal a partir de $10^{-2} \mathrm{mM}$ de AEME ( $p<$ 0,01). Os grupos incubados com AEME e atropina, tanto $1 \mu \mathrm{M}$ quanto $50 \mu \mathrm{M}$, foram diferentes em relação ao controle. No entanto, não houve diferença estatisticamente significativa em relação aos grupos AEME com atropina (ambas as concentrações) com o grupo AEME nas concentrações $10^{-1}, 10^{-2} \mathrm{e}$ $10^{-3} \mathrm{mM}$. Apenas no grupo incubado com AEME $1 \mathrm{mM}$, a atropina, tanto na concentração de $1 \mu \mathrm{M}(\mathrm{A})(p<0,05)$ quanto na de $50 \mu \mathrm{M}(\mathrm{B})(p<0,05)$, mostrou diminuição da morte neuronal em relação ao grupo tratado com a AEME isoladamente.

Atropina $1 \mu \mathrm{M}$

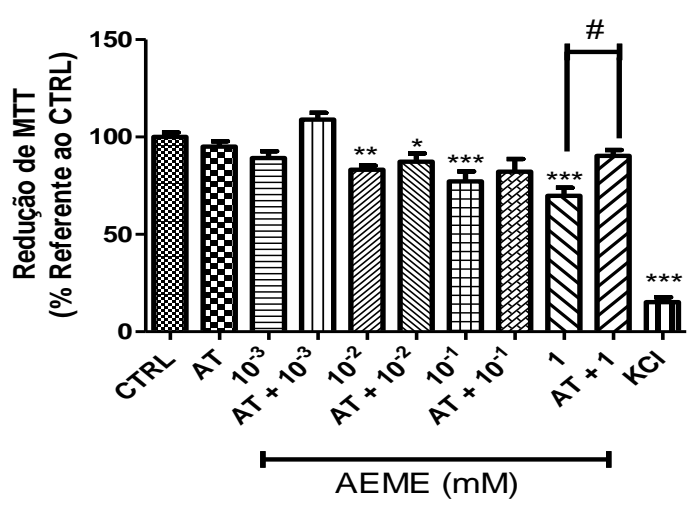

Atropina $50 \mu \mathrm{M}$

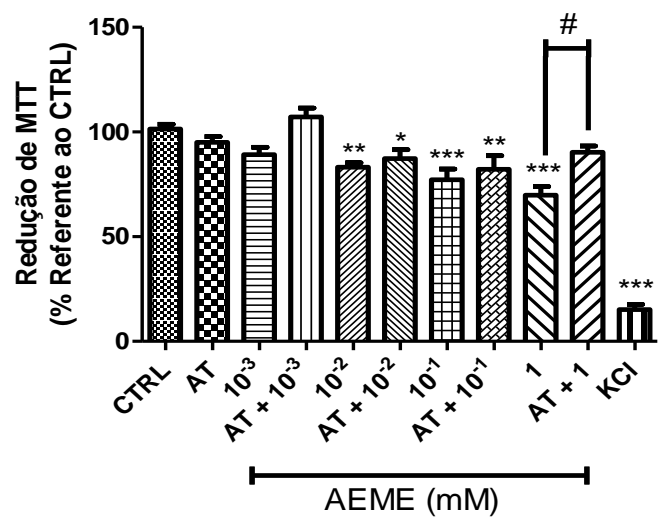

Figura 8. Resultados de viabilidade celular (MTT) após 24 horas de exposição à AEME em diferentes concentrações $(n=5)$. As células foram incubadas na ausência e na presença de atropina $1 \mu \mathrm{M}$; e $50 \mu \mathrm{M}$. CTRL = controle, AEME = metilecgonidina, $\mathrm{AT}=$ atropina. ${ }^{*} p<0,05$; ${ }^{* *} p<0,01$ e ${ }^{* * *} p<0,001$ (comparação do grupo tratado com o controle); ${ }^{\#} p<0,05$ (comparação do grupo tratado com o tratado com a substância de interesse na presença de atropina) (ANOVA e comparação múltipla de Newman-Keuls).

Quando os neurônios foram incubados com cocaína, a concentração de $2 \mathrm{mM}$ foi a única que apresentou morte neuronal significativa em relação ao 
controle $(p<0,001)$ (Figura 9). Não foi observado efeito da atropina (nas concentrações de 1 e $50 \mu \mathrm{M})$ na morte neuronal provocada pela cocaína. Este resultado indica que a atropina não protege este tipo de cultura celular dos efeitos neurotóxicos da cocaína (Figura 9).
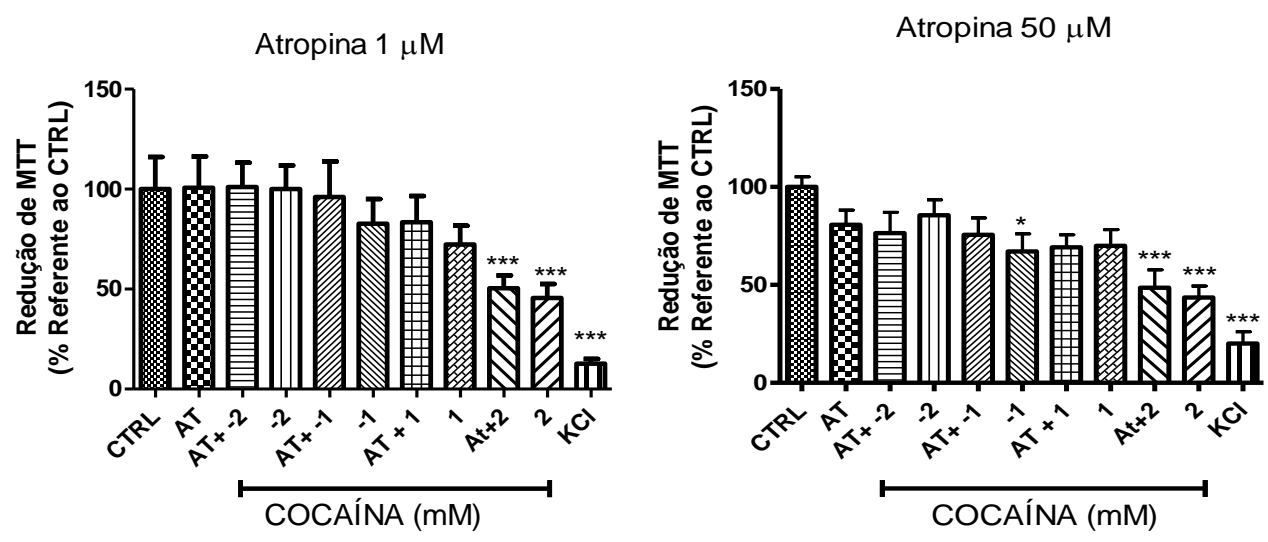

Figura 9. Resultados de viabilidade celular (MTT) após 24 horas de exposição à cocaína em diferentes concentrações $(n=6)$. As células foram incubadas na ausência e na presença de atropina $1 \mu \mathrm{M}$; e $50 \mu \mathrm{M}$. CTRL = controle, AT = atropina. ${ }^{*} p<0,05$ e ${ }^{* * *} p<0,001$ (comparação entre o grupo tratado com o controle) (ANOVA e comparação múltipla de Newman-Keuls).

Como pode ser visto na Figura 10, foi analisada a ação da associação (AEME $1 \mathrm{mM}$ /cocaína $2 \mathrm{mM}$ ), indicando que estas substâncias juntas provocam morte neuronal de aproximadamente $50 \%$ em relação ao controle $(p<0,01)$. A incubação prévia da cultura com atropina $(1 \mu \mathrm{M}$ e $50 \mu \mathrm{M})$ não mostrou proteção, uma vez que não reverteu a ação do tratamento com a associação (AEME 1 mM /cocaína 2 mM). 

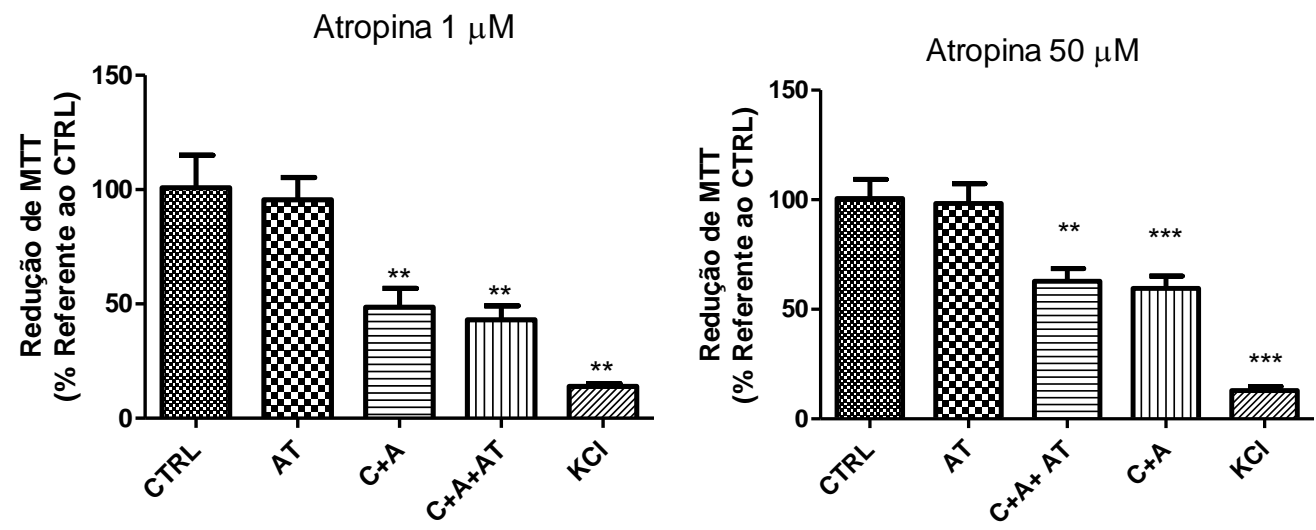

Figura 10. Resultados de viabilidade celular (MTT) após 24 horas de exposição à associação (AEME $1 \mathrm{mM} /$ cocaína $2 \mathrm{mM}$ ) $(\mathrm{n}=6)$. As células foram incubadas na ausência e na presença de atropina $1 \mu \mathrm{M}$; e $50 \mu \mathrm{M}$. CTRL = controle, $C+A$ = associação (AEME $1 \mathrm{mM} /$ cocaína $2 \mathrm{mM}$ ), AT $=$ atropina. ${ }^{* *} p<0,01$ e ${ }^{* * *} p<0,001$ (comparação entre 0 grupo tratado com 0 controle) (ANOVA e comparação múltipla de Newman-Keuls).

\subsection{FORMAÇÃO DE INOSITOL TRIFOSFATO $\left(\mathrm{IP}_{3}\right)$}

Foi avaliada a formação de trifosfato de inositol $\left(\mathrm{IP}_{3}\right)$, para isso foi preciso padronizar o método. Para a padronização, foi utilizado carbacol, um agonista muscarínico, utilizado como controle positivo. Pelo encontrado na padronização (Figura 11), o carbacol estimula a formação de $\mathrm{IP}_{3}$ em concentrações baixas, indicando que este tipo celular apresenta receptor colinérgico muscarínico, induzindo a formação de $\mathrm{IP}_{3}$.

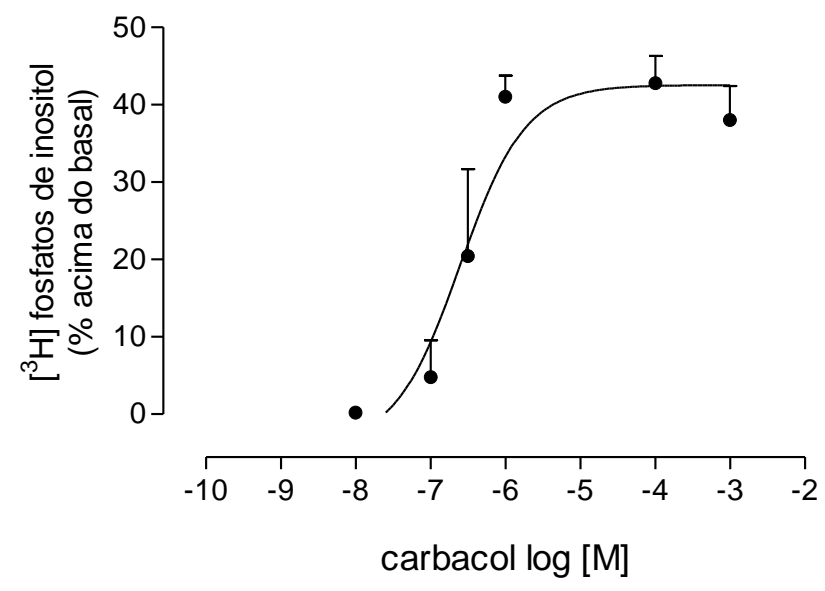

Figura 11. Resultado da padronização do método para verificar a formação de $\mathrm{IP}_{3}$ em neurônios, expostos ao carbacol, um agonita colinérgico muscarínico inespecífico. 
Após a padronização do método, foi possível realizar os testes com a AEME. De acordo com a figura 12, a AEME induziu a formação de $\mathrm{IP}_{3}$ a partir da concentração de $10^{-7} \mathrm{M}$.

Além disso, na concentração de $10^{-5} \mathrm{M}$ a formação de $\mathrm{IP}_{3}$ já entra em um platô, indicando que mesmo com aumento da concentração da AEME não haverá aumento na formação do $\mathrm{IP}_{3}$.

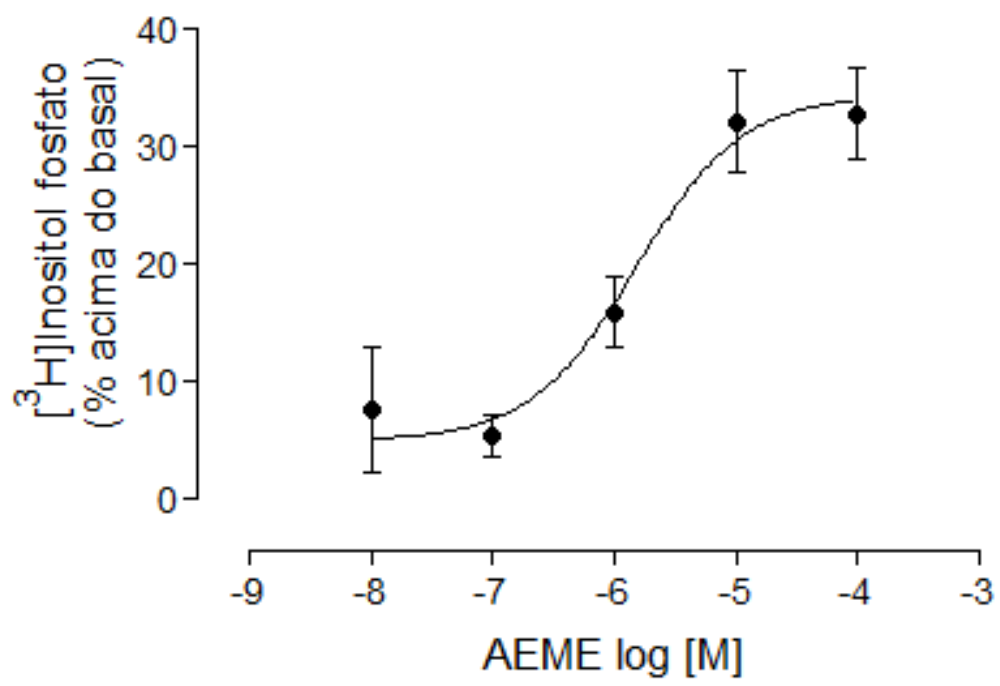

Figura 12. Resultado da formação de $\mathrm{IP}_{3}$ em neurônios, incubados com $\mathrm{AEME}$ em diferentes concentrações $(n=5)$.

\subsection{CONCENTRAÇÃO DE CÁLCIO INTRACELULAR}

O aumento do cálcio intracelular após incubação da cultura primária de hipocampo com AEME foi dependente da concentração, ou seja, quanto maior sua concentração, maior a concentração de cálcio intracelular liberado. Como pode ser observado na figura 13, há aumento de cálcio intracelular na concentração de $10^{-1} \mathrm{mM}$ de $\operatorname{AEME}(p<0,05)$. Este efeito permanece quando os neurônios são incubados com AEME na concentração de 1 mM $(p<0,001)$.

Em relação à cocaína, somente a concentração de $2 \mathrm{mM}$ mostrou aumento significativo de cálcio em relação ao controle $(p<0,001)$ (Figura 13). $O$ 
aumento de cálcio com esta concentração de cocaína mostrou-se significativamente maior $(p<0,001)$ do que todos os outros grupos tratados.

A incubação da associação (AEME $1 \mathrm{mM} /$ cocaína $2 \mathrm{mM}$ ) apresentou aumento significativo da liberação de cálcio intracelular em relação ao controle $(p<0,001)$, contudo não houve diferença quando comparado com os grupos das substâncias isoladas (AEME $1 \mathrm{mM}$ e cocaína $2 \mathrm{mM}$ ) (Figura 13).
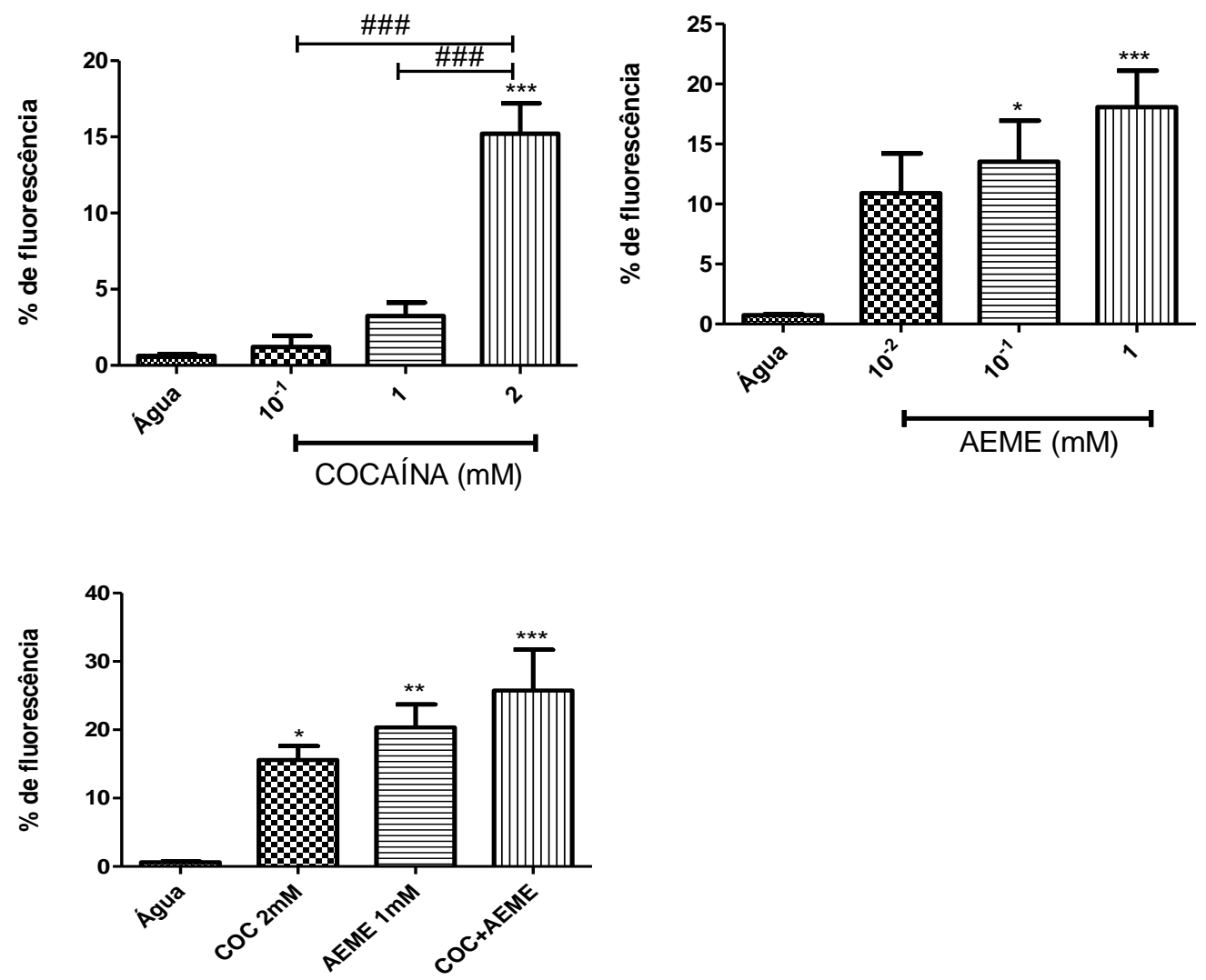

Figura 13. Ensaios da concentração de cálcio intracelular em neurônios $(n=10)$. Exposição à cocaína; Exposição à AEME; Exposição à associação (AEME $1 \mathrm{mM} /$ cocaína $2 \mathrm{mM}$ ). CTRL = controle, $\mathrm{COC}=$ cocaína, $\mathrm{AEME}=$ metilecgonidina. ${ }^{*} p<0,05 ;{ }^{* *} p<0,01$ e ${ }^{* * *} p<0,001$ (comparação entre o grupo tratado com o controle); ${ }^{\# \#} p<0,001$ (diferença em relação aos grupos tratados) (ANOVA e comparação múltipla de Newman-Keuls).

\subsection{INTEGRIDADE DA MEMBRANA CELULAR}

As células foram avaliadas por citometria de fluxo para verificar a integridade da membrana celular, indício de morte celular por necrose. 
Inicialmente as células foram incubadas por 12 horas, período em que foi encontrada morte celular no grupo associação (AEME $1 \mathrm{mM} /$ cocaína 2 mM). Foi possível verificar que, neste período de incubação (Figura 14), apenas o grupo da associação perdeu a integridade da membrana $(p<0,001)$, sendo encontrada diferença em relação ao controle. Esta diminuição foi diferente também dos grupos isolados AEME $1 \mathrm{mM}(p<0,05)$ e da cocaína $2 \mathrm{mM}$ $(p<0,05)$. Na figura 15 estão algumas figuras representativas da citometria de fluxo.
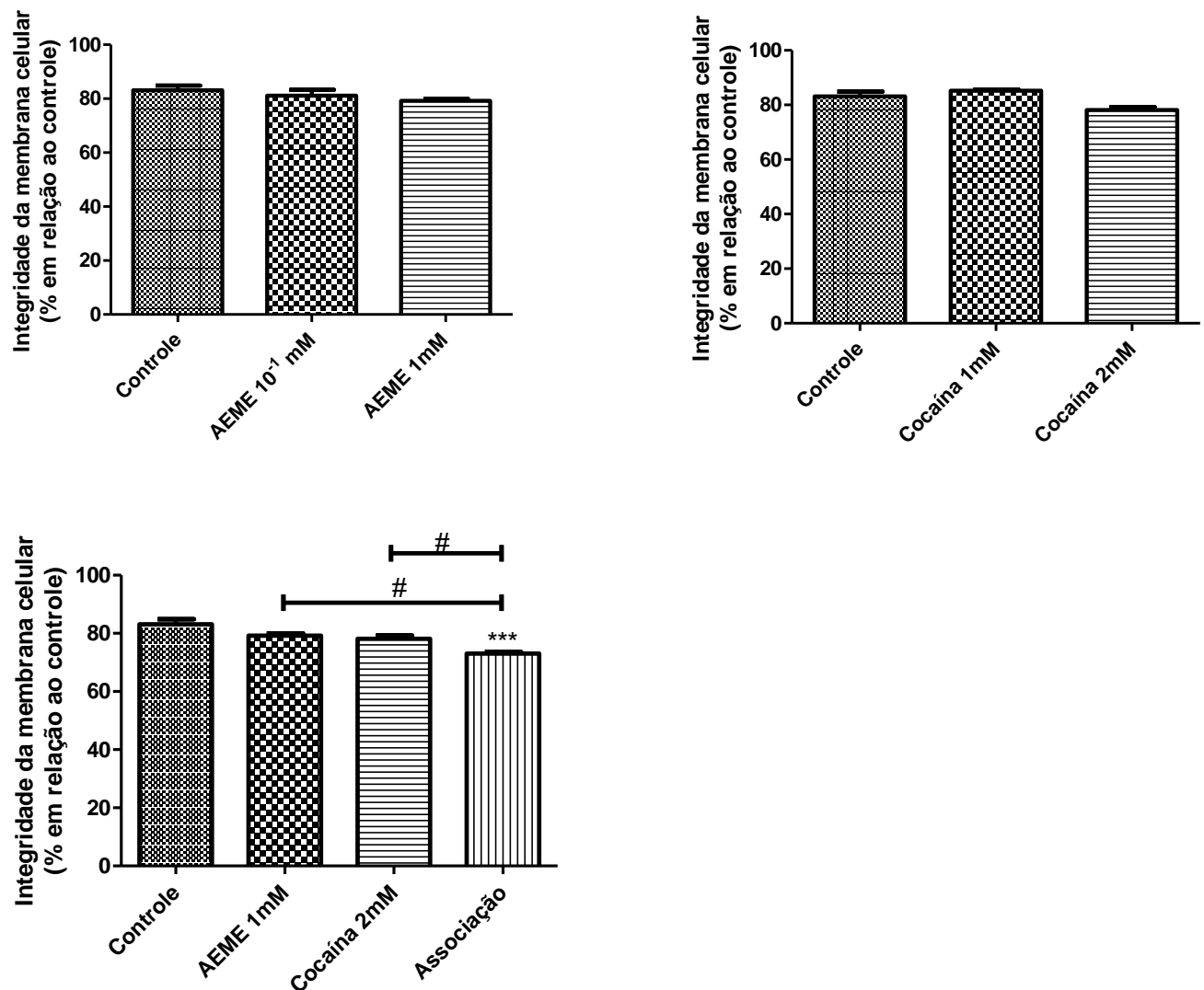

Figura 14. Integridade da membrana celular da cultura primária de hipocampo $(n=3)$. Exposição à AEME, cocaína e associação (AEME $1 \mathrm{mM} /$ cocaína $2 \mathrm{mM}$ ) por 12 horas. ${ }^{* *} p<0,001$ (comparação do grupo tratado com o controle); ${ }^{\#} p<0,05$ (diferença em relação aos grupos tratados) (ANOVA e comparação múltipla de Newman-Keuls). 

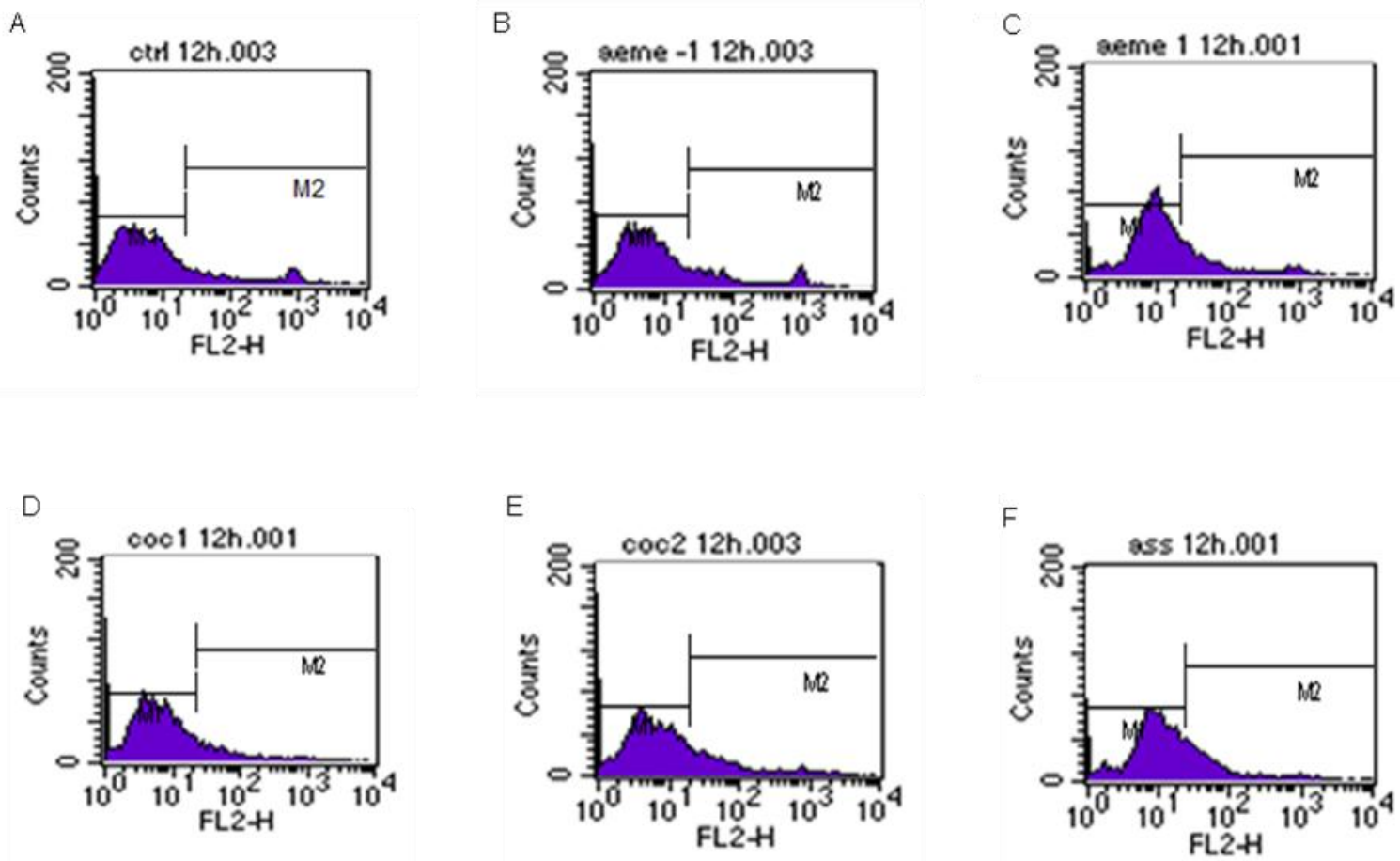

Figura 15. Imagens representativas da análise por citometria de fluxo, para a determinação da integridade da membrana celular. $A=$ controle; $B=A E M E 10^{-1} \mathrm{mM} ; C=A E M E 1 \mathrm{mM} ; D=$ Cocaína $1 \mathrm{mM} ; \mathrm{E}$ = Cocaína $2 \mathrm{mM}$; $\mathrm{F}$ = Associação (AEME $1 \mathrm{mM} /$ Cocaína $2 \mathrm{mM}$ ). A população em M1 significa porcentagem de células com DNA fragmentado e M2 a porcentagem de células com DNA não fragmentado.

O mesmo experimento foi realizado após 24 horas de incubação com AEME $10^{-1}$ e $1 \mathrm{mM}$; cocaína 1 e $2 \mathrm{mM}$; e associação (AEME $1 \mathrm{mM} /$ cocaína 2 mM). Neste caso foi observado que a AEME, nas duas concentrações, diminuiu a integridade da membrana $(p<0,05)$ (Figura 16). $O$ mesmo resultado foi encontrado quando a cultura de neurônio foi incubada com cocaína, houve diminuição da integridade da membrana celular nas duas concentrações testadas, $1 \mathrm{mM}(p<0,05)$ e $2 \mathrm{mM}(p<0,01)$ (Figura 16).

Quando os neurônios foram incubados com associação (AEME $1 \mathrm{mM}$ /cocaína $2 \mathrm{mM}$ ), houve perda significativa da integridade da membrana em relação ao controle $(p<0,001)$. Foi encontrada diferença estatisticamente significativa entre a associação (AEME $1 \mathrm{mM}$ /cocaína $2 \mathrm{mM}$ ) e as substâncias isoladas, como AEME $(p<0,001)$ e cocaína $(p<0,01)$ (Figura 16). Na figura 17 
estão representadas algumas figuras dos gráficos adquiridos por citometria de fluxo.
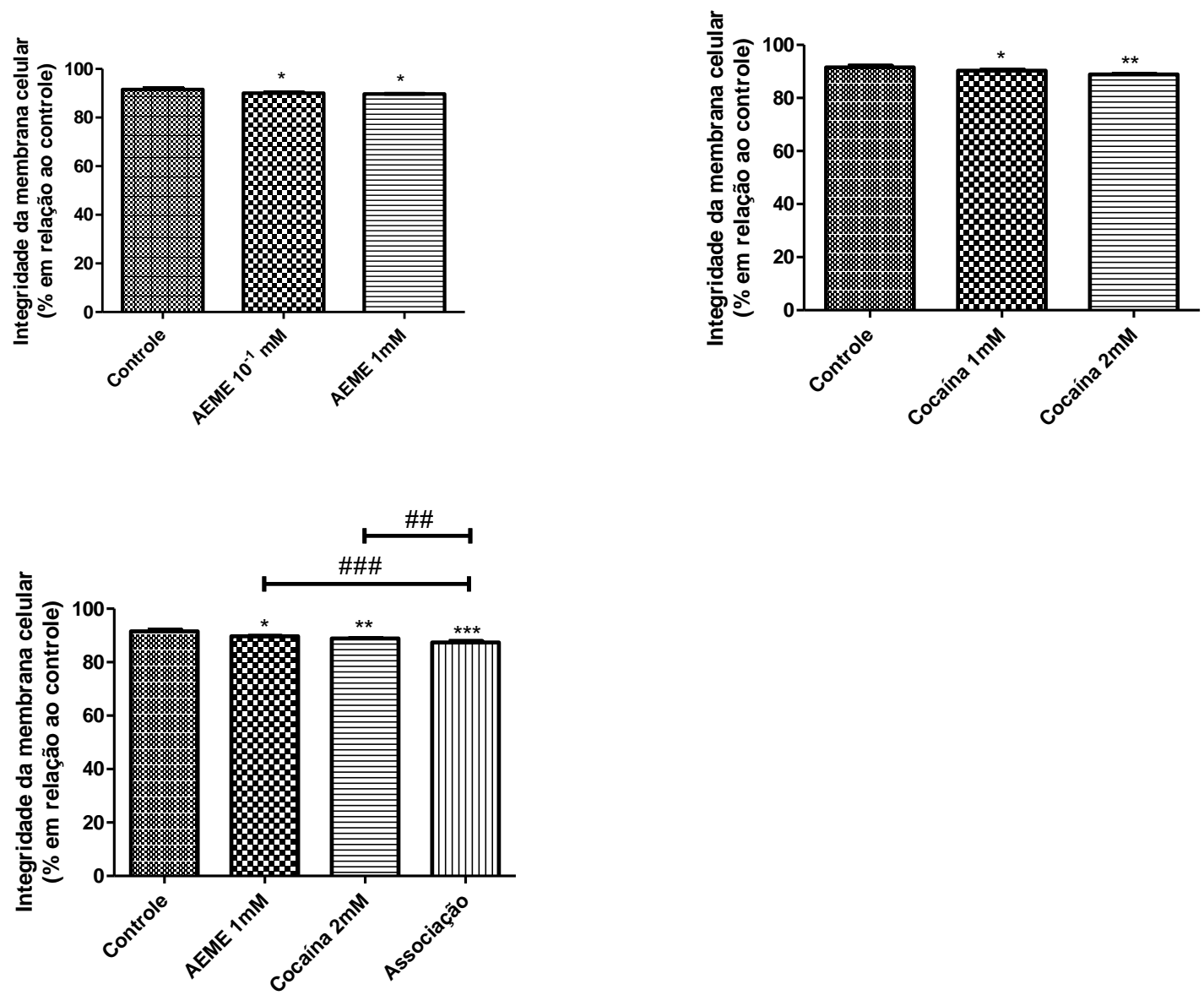

Figura 16. Integridade da membrana celular da cultura primária de hipocampo $(n=4)$. Exposição à AEME, cocaína e associação (AEME $1 \mathrm{mM} /$ cocaína $2 \mathrm{mM}$ ) por 24 horas $(\mathrm{n}=4)$. ${ }^{* * *} p<0,001$ (comparação do grupo tratado com o controle); ${ }^{* \#} p<0,01$ e ${ }^{\# \# \#} p<0,001$ (diferença em relação aos grupos tratados) (ANOVA e comparação múltipla de Newman-Keuls). 
A

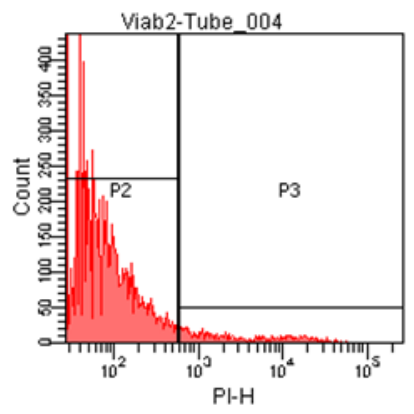

D

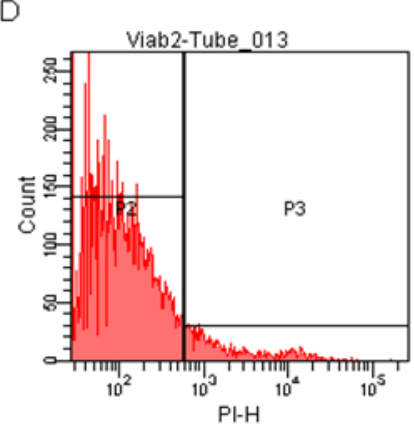

B

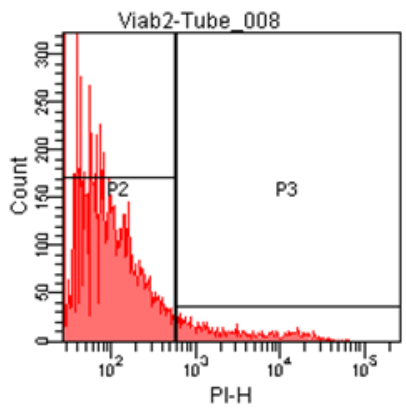

E

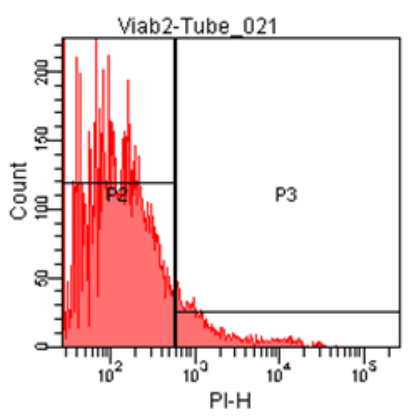

C

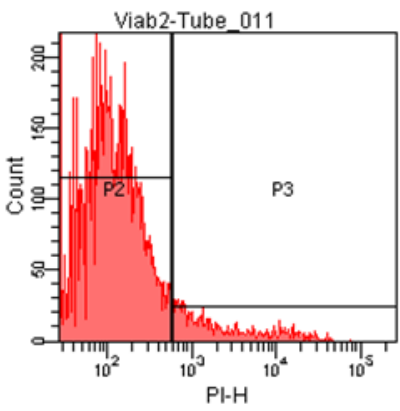

$\mathrm{F}$

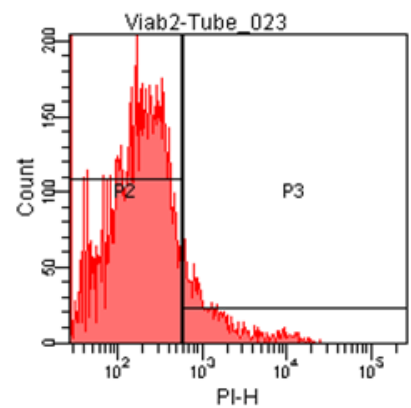

Figura 17. Imagens representativas da análise por citometria de fluxo, para a determinação da fragmentação do DNA. $A$ = controle; $B=A E M E ~ 10^{-1} \mathrm{mM} ; C=A E M E 1 \mathrm{mM}$; $D$ = Cocaína $1 \mathrm{mM}$; $E$ = Cocaína $2 \mathrm{mM} ; \mathrm{F}$ = Associação (AEME $1 \mathrm{mM} /$ Cocaína 2mM). A população em M1 significa porcentagem de células com DNA fragmentado e M2 a porcentagem de células com DNA não fragmentado.

\subsection{FRAGMENTAÇÃO DE DNA}

Para verificar se as células estavam em apoptose, foi realizada a análise da fragmentação do DNA. As células foram incubadas por 12 horas, período em que foi visto por GARCIA et al. 2012 o início da morte celular. Como pode ser visto na figura 18, não foi encontrado diferença significativa no grupo incubado com AEME $10^{-1}$ e $1 \mathrm{mM}$.

Em contrapartida, no grupo da cocaína, foi encontrada uma diferença significativa na concentração de $2 \mathrm{mM}$ em relação ao controle $(p<0,05)$, indicando que as células já estão com DNA fragmentado. Diferente do que ocorre com as células incubadas com cocaína $1 \mathrm{mM}$, em que não foi encontrado diferença significativa (Figura 18). Contudo, quando as células foram incubadas com a associação (AEME $1 \mathrm{mM}$ /cocaína $2 \mathrm{mM}$ ), foi visto um 
aumento significativo da fragmentação do DNA em relação ao controle $(p<0,01)$

e também em relação aos grupos incubados com as substâncias isoladas, como AEME $1 \mathrm{mM}(p<0,001)$ e da cocaína $2 \mathrm{mM}(p<0,05)$ (Figura 18). Na figura 19, pode-se observar imagens representativas das análises realizadas para verificar a fragmentação do DNA.
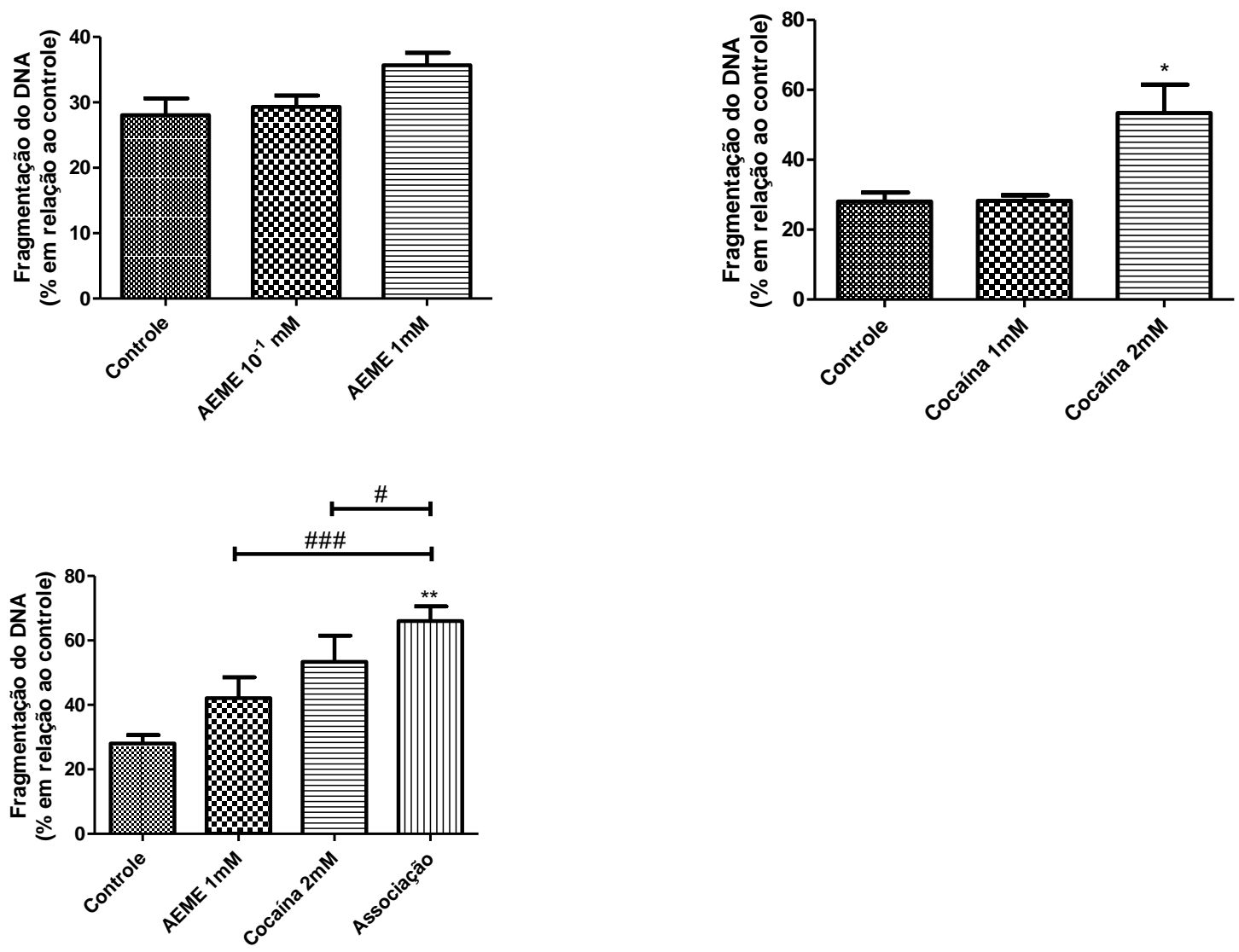

Figura 18. Fragmentação do DNA da cultura primária de hipocampo após a exposição à AEME, cocaína e associação (AEME $1 \mathrm{mM}$ /cocaína $2 \mathrm{mM})$ por 12 horas $(n=3)$. ${ }^{*} p<0,05$; ${ }^{* *} p<0,01$ (comparação do grupo tratado com o controle); ${ }^{\#} p<0,05 e^{\# \#} p<0,001$ (diferença em relação aos grupos tratados) (ANOVA e comparação múltipla de Newman-Keuls). 

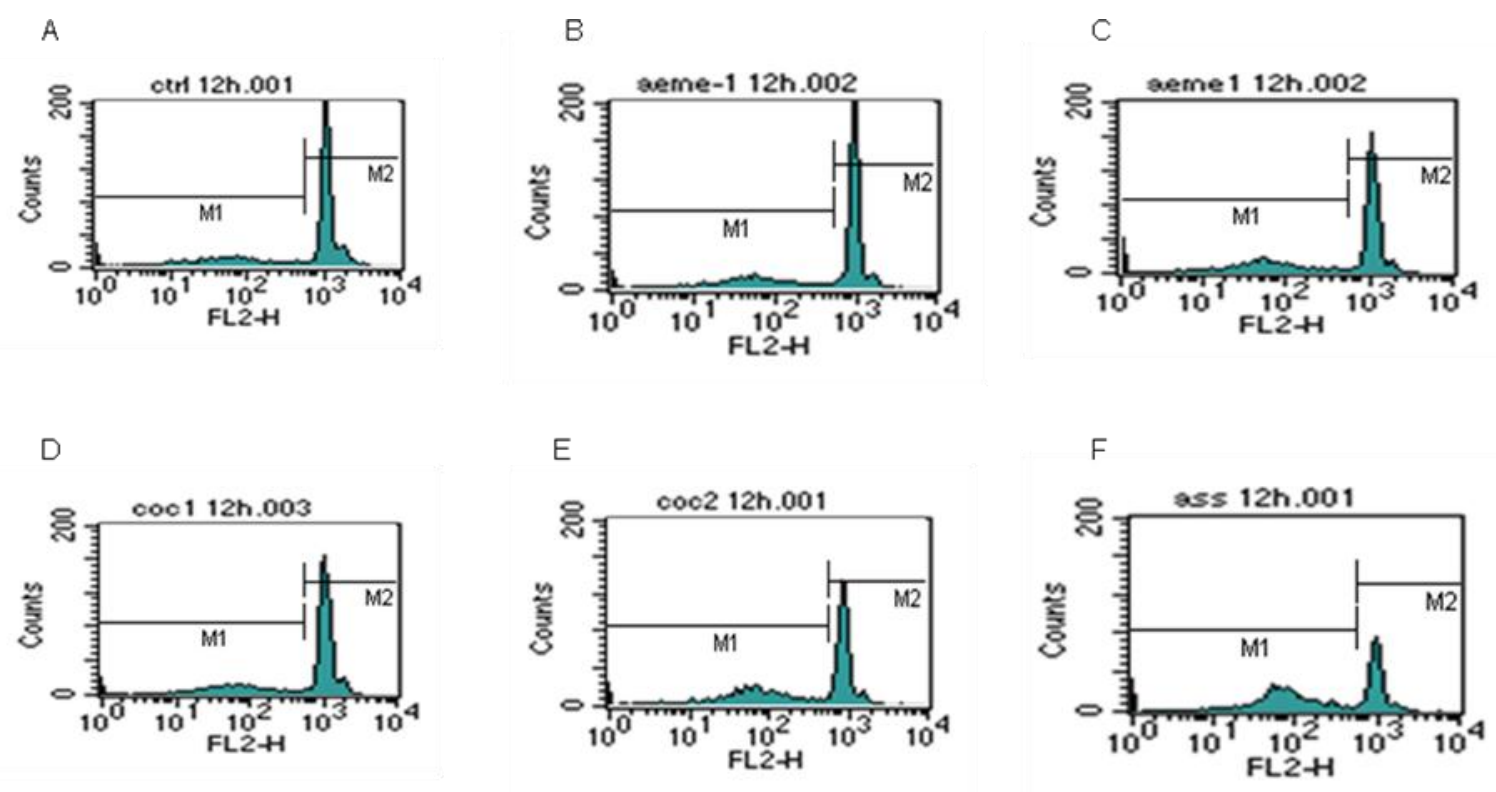

Figura 19. Imagens representativas da análise por citometria de fluxo, para a determinação da fragmentação do DNA. $A$ = controle; $B=A E M E 10^{-1} \mathrm{mM} ; C=A E M E 1 \mathrm{mM} ; \mathrm{D}=$ Cocaína $1 \mathrm{mM}$; $E$ = Cocaína $2 \mathrm{mM} ; \mathrm{F}$ = Associação (AEME $1 \mathrm{mM} /$ Cocaína $2 \mathrm{mM}$ ). A população em $\mathrm{M} 1$ significa porcentagem de células com DNA fragmentado e M2 a porcentagem de células com DNA não fragmentado.

Os mesmos parâmetros foram analisados com as mesmas substâncias após 24 horas de incubação. Os neurônios incubados com AEME $10^{-1} \mathrm{mM}$ não apresentaram diferença significativa em relação ao controle. No entanto, quando incubado com AEME $1 \mathrm{mM}$, houve fragmentação de DNA $(p<0,01)$ em relação ao controle e também com diferença em relação ao grupo AEME $10^{-1}$ $\mathrm{mM}(p<0,05)$ (Figura 20). A AEME 1 mM apresentou fragmentação de DNA em torno de $45 \%$ da população total de neurônios.

Quando a cultura foi incubada com cocaína, foi encontrado diferença significativa em relação ao controle nas duas concentrações testadas, $1 \mathrm{mM}$ $(p<0,001)$ e $2 \mathrm{mM}(p<0,001)$. Foi visto também que, quando analisado a porcentagem de DNA fragmentado, a concentração de $2 \mathrm{mM}$ é diferente da concentração de $1 \mathrm{mM}(p<0,001)$ (Figura 20).

Como pode ser observado na figura 20 , quando os neurônios foram incubados com a associação (AEME $1 \mathrm{mM}$ /cocaína $2 \mathrm{mM}$ ), foi encontrado um 
aumento da fragmentação do DNA em torno de $70 \%$ da população total das células, sendo, desta forma, significativamente diferente em relação ao controle $(p<0,001)$. Quando avaliado em relação aos grupos isolados, a associação (AEME $1 \mathrm{mM}$ /cocaína $2 \mathrm{mM}$ ) foi diferente apenas do grupo incubado com AEME $1 \mathrm{mM}(p<0,05)$, não sendo encontrada diferença em relação ao grupo incubado com cocaína $2 \mathrm{mM}$. A figura 21 esta representando alguns gráficos produzidos pela análise de citometria de fluxo.
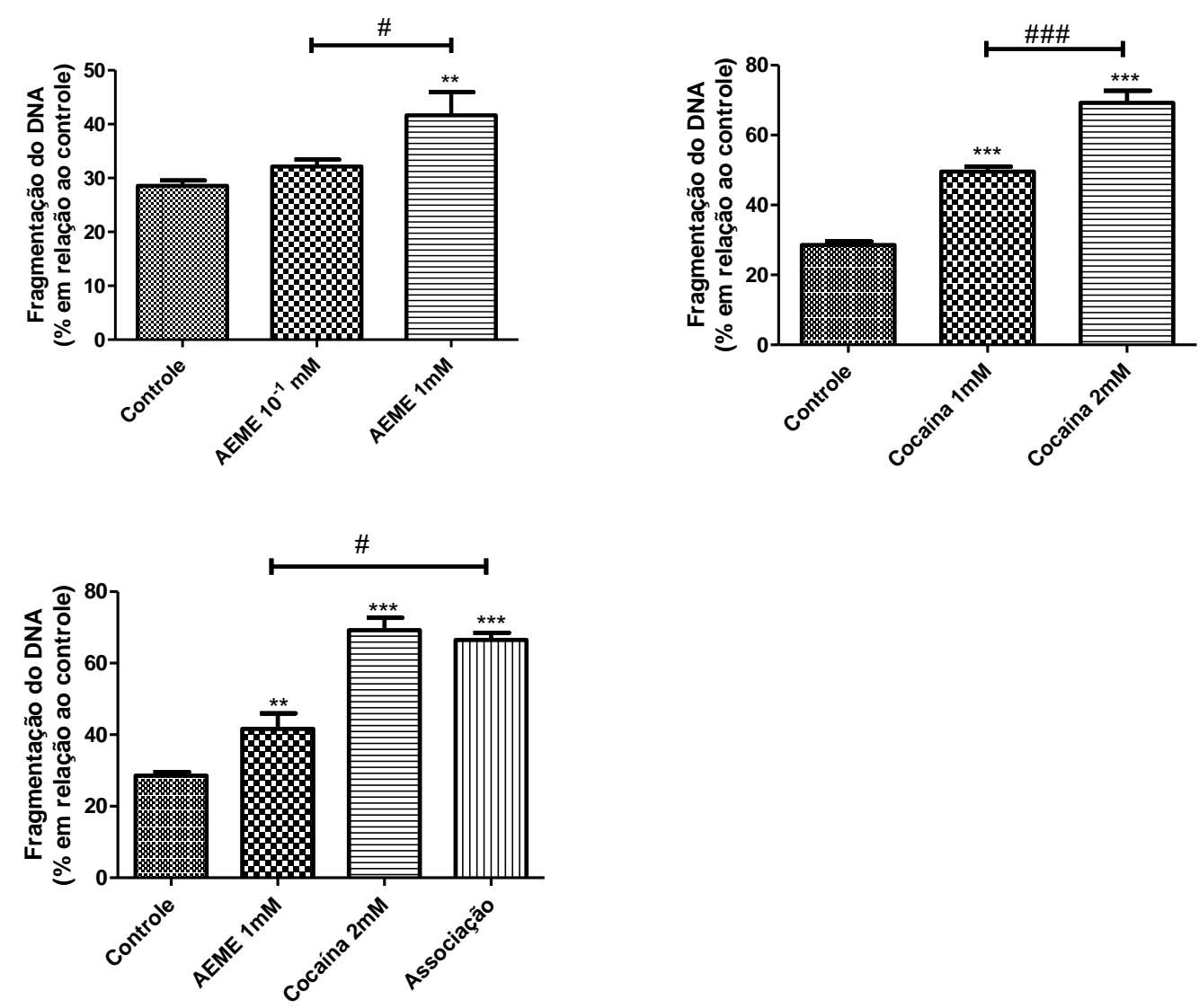

Figura 20. Fragmentação do DNA da cultura primária de hipocampo após a exposição à AEME, cocaína e associação (AEME $1 \mathrm{mM} /$ cocaína $2 \mathrm{mM}$ ) por 24 horas. ${ }^{*} p<0,05$; ${ }^{*} p<0,01$ (comparação do grupo tratado com o controle); ${ }^{\#} p<0,05 ;{ }^{\# \#} p<0,001$ (diferença em relação aos grupos tratados) (ANOVA e comparação múltipla de Newman-Keuls). 
A
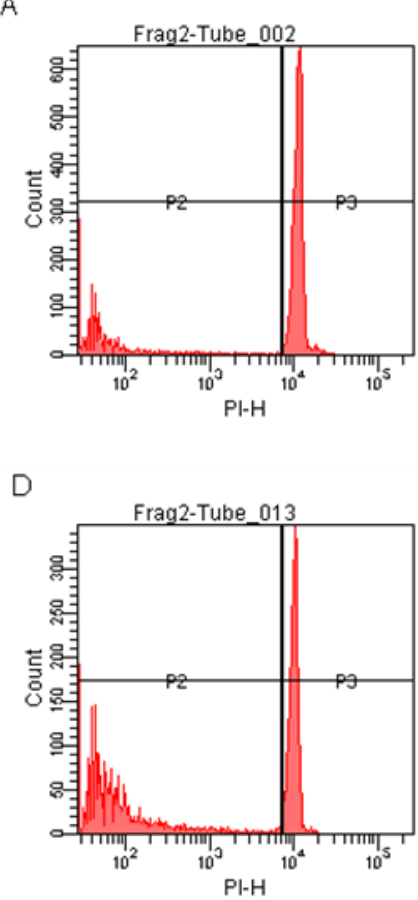

B

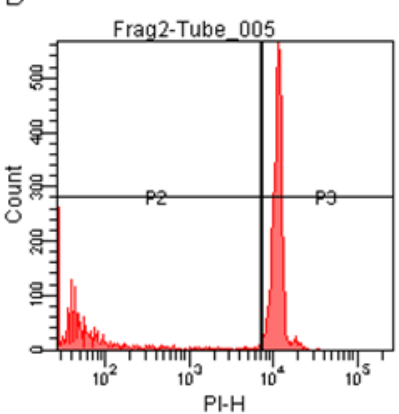

E

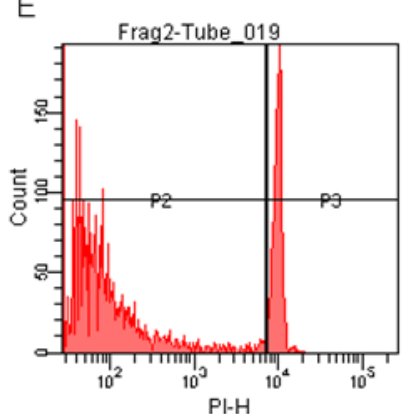

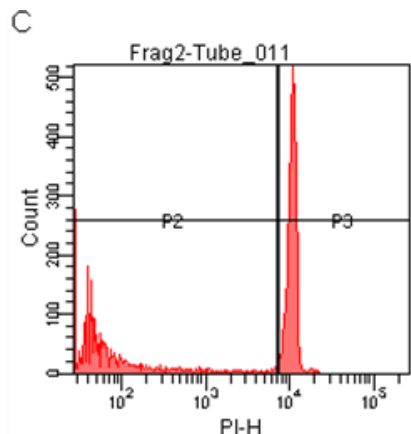

F

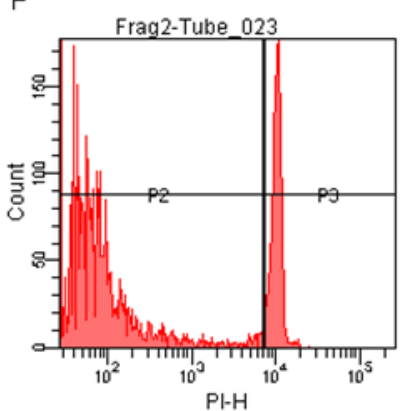

Figura 21. Imagens representativas da análise por citometria de fluxo, para a determinação da integridade da membrana celular. $A=$ controle; $B=A E M E 10^{-1} \mathrm{mM} ; C=A E M E 1 \mathrm{mM} ; D=$ Cocaína $1 \mathrm{mM} ; \mathrm{E}$ = Cocaína $2 \mathrm{mM} ; \mathrm{F}$ = Associação (AEME $1 \mathrm{mM} /$ Cocaína $2 \mathrm{mM}$ ). A população em M1 significa porcentagem de células com DNA fragmentado e M2 a porcentagem de células com DNA não fragmentado.

\subsection{EXPRESSÃO DE PROTEÍNAS MITOCONDRIAIS: BAX E BCL-2}

As células foram incubadas por 30, 180 e 360 minutos, períodos anteriores à morte celular, com cocaína 1 e $2 \mathrm{mM}$; AEME $10^{-1}$ e $1 \mathrm{mM}$; e a associação (AEME $1 \mathrm{mM}$ /cocaína $2 \mathrm{mM}$ ). Os resultados da Bcl-2 e da Bax foram expressos em relação à banda da proteína constitutiva que, neste caso, foi o GAPDH.

Inicialmente, as membranas de nitrocelulose foram coradas com Ponceau para verificar a presença de proteínas. Desta forma, foi possível garantir a qualidade da membrana em relação às bandas controle destacadas pelo padrão (Figura 22). 

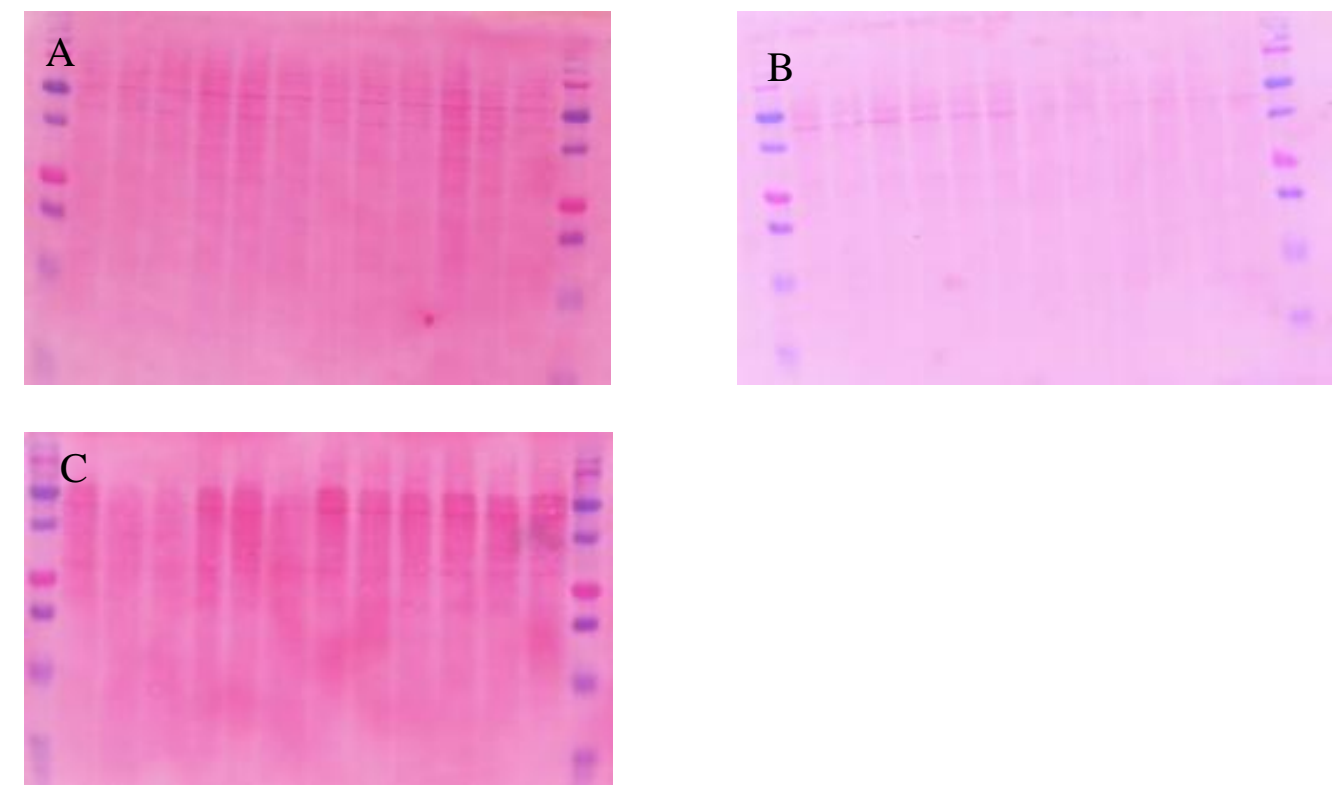

Figura 22. Imagens representativas das membranas de nitrocelulose coradas com Ponceau. A) amostras incubadas após 30 minutos, B) incubação de 3 horas, C) incubação de 6 horas. Na mesma membrana, foram analisadas diferentes grupos de tratamento e incubadas com os 3 anticorpos .

Para o melhor entendimento da dinâmica de sinalização intracelular das proteínas mitocondriais, foi realizada a razão entre a proteína Bax (próapoptótica) com a Bcl-2 (antiapoptótica).

Após 30 minutos de incubação, não foi observada mudança em relação à expressão destas proteínas (Figura 23). 


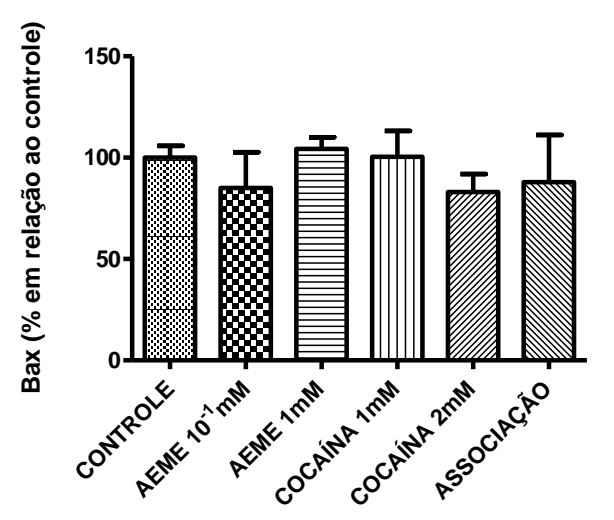

$\operatorname{Bax}$

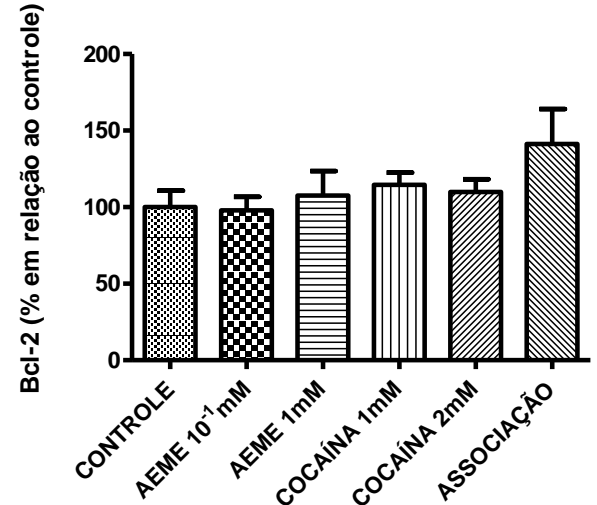

Bcl-2

$28 \mathrm{KDa}$

GAPDH

$37 \mathrm{KDa}$

$37 \mathrm{KDa}$

Figura 23. Expressão de proteínas mitocondriais Bax e Bcl-2 em cultura primária de hipocampo $(\mathrm{n}=4)$. Exposição à AEME, cocaína e associação (AEME $1 \mathrm{mM} /$ cocaína $2 \mathrm{mM}$ ) por 30 minutos. (ANOVA e comparação múltipla de Newman-Keuls).

Não foi encontrada mudança significativa na razão entre $\mathrm{Bax} / \mathrm{Bcl}-2$, indicando que, no período de incubação de 30 minutos, não há alteração da expressão destas proteínas (Figura 24).

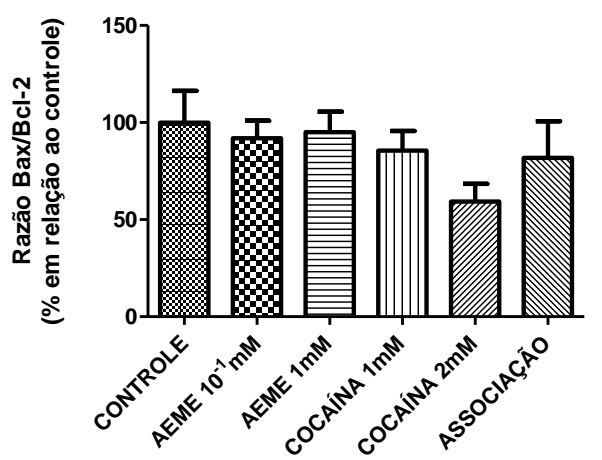

Figura 24. Razão entre as proteínas mitocondriais $\mathrm{Bax}$ e $\mathrm{Bcl}-2$ em cultura primária de hipocampo $(n=4)$. Exposição à $A E M E$, cocaína e associação (AEME $1 \mathrm{mM} /$ cocaína $2 \mathrm{mM}$ ) por 30 minutos. (ANOVA e comparação múltipla de Newman-Keuls).

Após 3 horas de incubação com AEME tanto na concentração de $10^{-1}$ quanto na de $1 \mathrm{mM}$, foi observado um aumento da proteína Bax $(p<0,001$ e $p<0,01$, respectivamente) (Figura 25). No entanto, não foi evidenciado aumento da expressão destas proteínas após a incubação com cocaína (1 
mM e $2 \mathrm{mM}$ ) e associação (AEME $1 \mathrm{mM}$ /cocaína $2 \mathrm{mM}$ ). Contudo, quando avaliada a expressão da proteína $\mathrm{Bcl}-2$, verificamos uma diminuição $(p<0,05)$ nos grupos da AEME (10-1 e $1 \mathrm{mM}$ ) e da cocaína (1 e $2 \mathrm{mM}$ ) em relação ao controle. Já no grupo da associação (AEME $1 \mathrm{mM} /$ cocaína $2 \mathrm{mM}$ ) foi encontrada uma diminuição estatisticamente significativa da Bcl-2 em relação ao controle $(p<0,01)$ (Figura 25).

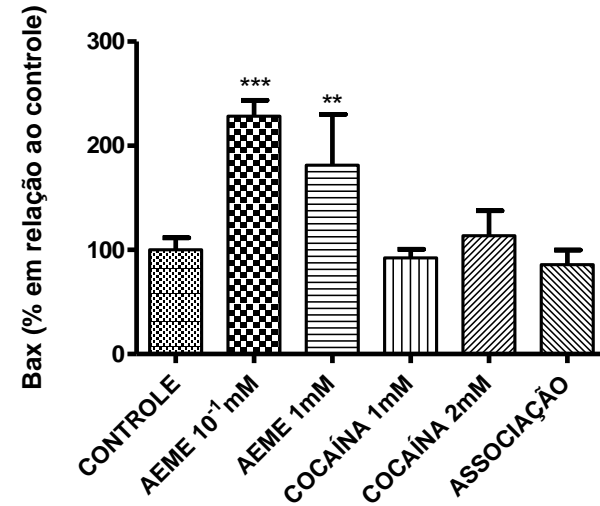

Bax

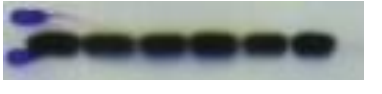

$20 \mathrm{KDa}$

GAPDH

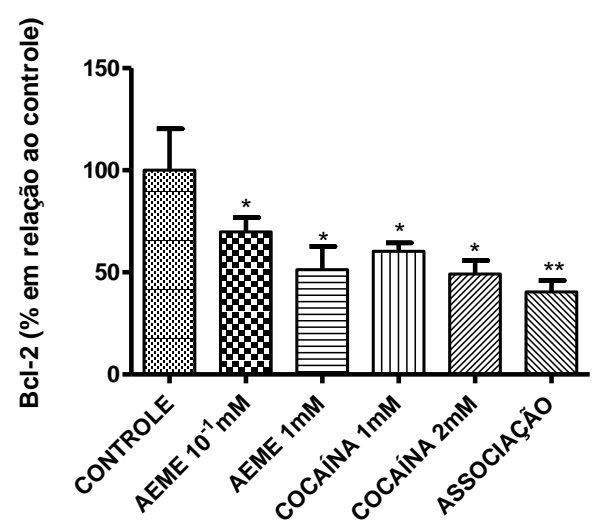

Bcl-2

$28 \mathrm{KDa}$

$37 \mathrm{KDa}$

GAPDH

$37 \mathrm{KDa}$

Figura 25. Expressão de proteínas mitocondriais Bax e Bcl-2 em cultura primária de hipocampo $(\mathrm{n}=4)$. Exposição à AEME, cocaína e associação (AEME $1 \mathrm{mM}$ /cocaína $2 \mathrm{mM}$ ) por 3 horas. ${ }^{*} p<0,05 ;{ }^{* *} p<0,01 e^{* * *} p<0,001$ (comparação do grupo tratado com o controle). (ANOVA $e$ comparação múltipla de Newman-Keuls).

Além do resultado individual, é de extrema importância a avaliação da razão entre a expressão da Bax e Bcl-2. Por meio desta análise, foi possível verificar que o efeito pró-apoptótico está mais acentuado $(p<0,01)$ e prevalece nos neurônios incubados com AEME nas duas concentrações testadas (Figura 26). 


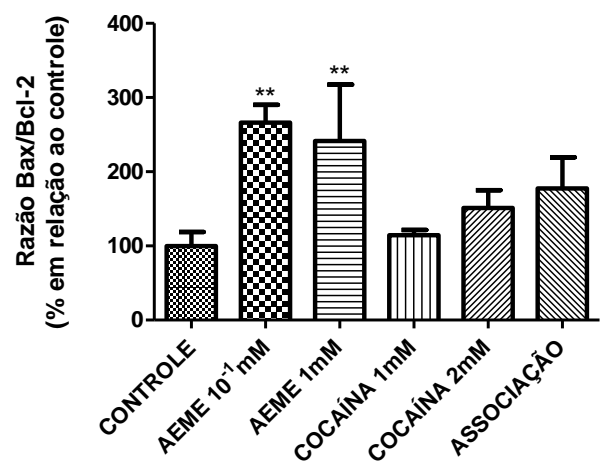

Figura 26. Razão entre as proteínas mitocondriais Bax e $\mathrm{Bcl}-2$ em cultura primária de hipocampo $(n=4)$. Exposição à $A E M E$, cocaína e associação (AEME $1 \mathrm{mM} /$ cocaína $2 \mathrm{mM}$ ) por 3 horas. ${ }^{*} p<0,01$ (comparação do grupo tratado com o controle). (ANOVA e comparação múltipla de Newman-Keuls).

Por fim, foi analisada a expressão das proteínas no período de 6 horas. Neste período, foi observado que as duas proteínas estão com a porcentagem significativamente menor em relação ao controle (Figura 27). Quando foi avaliada a expressão da proteína Bax, os neurônios incubados com AEME $\left(10^{-1}\right.$ e $\left.1 \mathrm{mM}\right)$ apresentaram expressão menor em relação ao controle $(p<0,01)$. Tanto os grupos incubados com cocaína na concentração de $1 \mathrm{mM}$ quanto $2 \mathrm{mM}$ apresentaram diminuição da expressão da Bax $(p<0,01$ e $p<0,001$, respectivamente). Em contrapartida, no grupo da associação (AEME $1 \mathrm{mM}$ /cocaína $2 \mathrm{mM}$ ), a expressão da Bax ficou semelhante ao controle.

Em relação à expressão da proteína $\mathrm{Bcl}-2$, todos os grupos apresentaram uma diminuição significativa em relação ao controle $(p<0,01)$ (Figura 27). 


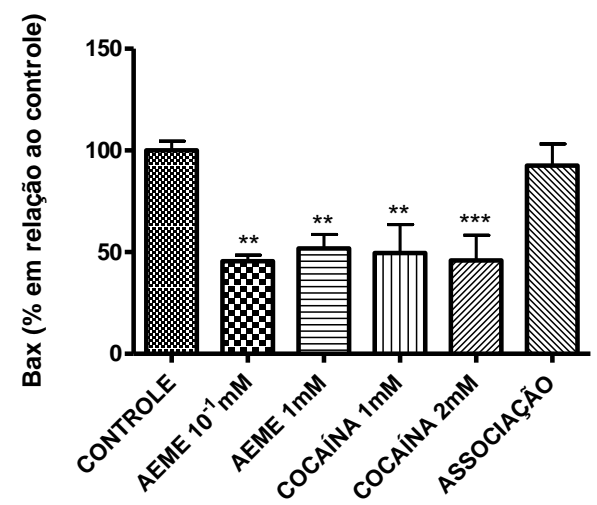

Bax

$20 \mathrm{KDa}$

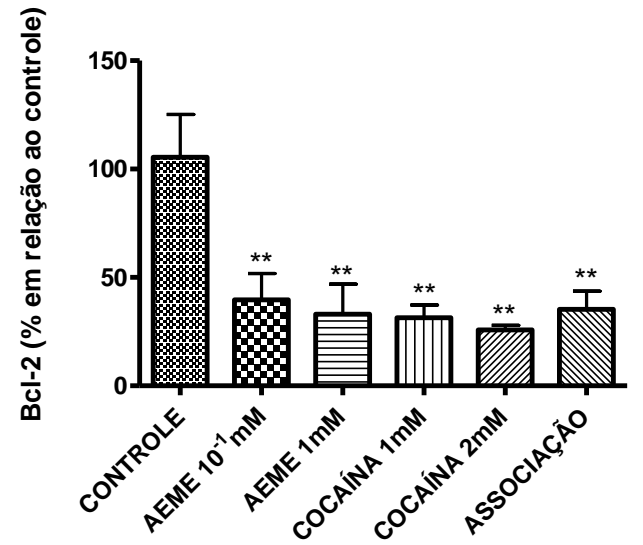

Bcl-2
$28 \mathrm{KDa}$

\section{$37 \mathrm{KDa}$}

\section{GAPDH}

$37 \mathrm{KDa}$

GAPDH

Figura 27. Expressão de proteínas mitocondriais Bax e Bcl-2 em cultura primária de hipocampo
$(\mathrm{n}=4)$. Exposição à $A E M E$, cocaína e associação (AEME $1 \mathrm{mM} /$ cocaína $2 \mathrm{mM}$ ) por 6 horas. ${ }^{* *} p<0,01 e{ }^{* * *} p<0,001$ (comparação do grupo tratado com o controle). (ANOVA e comparação múltipla de Newman-Keuls).

Por meio da razão entre a Bax e Bcl-2, foi encontrado um aumento da razão no grupo da associação (AEME $1 \mathrm{mM}$ /cocaína $2 \mathrm{mM}$ ) quando comparado ao controle. Esta razão indica que a Bcl-2 está menos expressa em relação à Bax, uma vez que a Bax está com expressão similar ao controle (Figura 28).

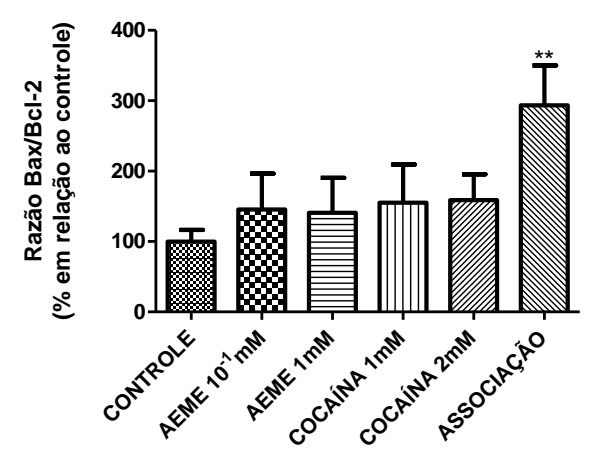

Figura 28. Razão entre as proteínas mitocondriais $\mathrm{Bax}$ e $\mathrm{Bcl}-2$ em cultura primária de hipocampo $(n=4)$. Exposição à AEME, cocaína e associação (AEME $1 \mathrm{mM} /$ cocaína $2 \mathrm{mM})$ por 6 horas. ${ }^{* *} p<0,01$ (comparação do grupo tratado com o controle). (ANOVA e comparação múltipla de Newman-Keuls). 


\subsection{ATIVIDADE DA CASPASE-3}

A atividade da caspase-3 foi avaliada após 3 e 6 horas de incubação, períodos em que ainda não houve morte celular, evidenciado a partir dos ensaio de MTT.

Não foi encontrado aumento na atividade da caspase-3 nos neurônios incubados com AEME nas duas concentrações por 3 horas (Figura 29). Em contrapartida, após 6 horas de incubação com AEME, houve um aumento da atividade da caspase-3 nas duas concentrações testadas $\left(10^{-1}\right.$ e $\left.1 \mathrm{mM}\right)$ quando comparado ao controle $(p<0,05)$.
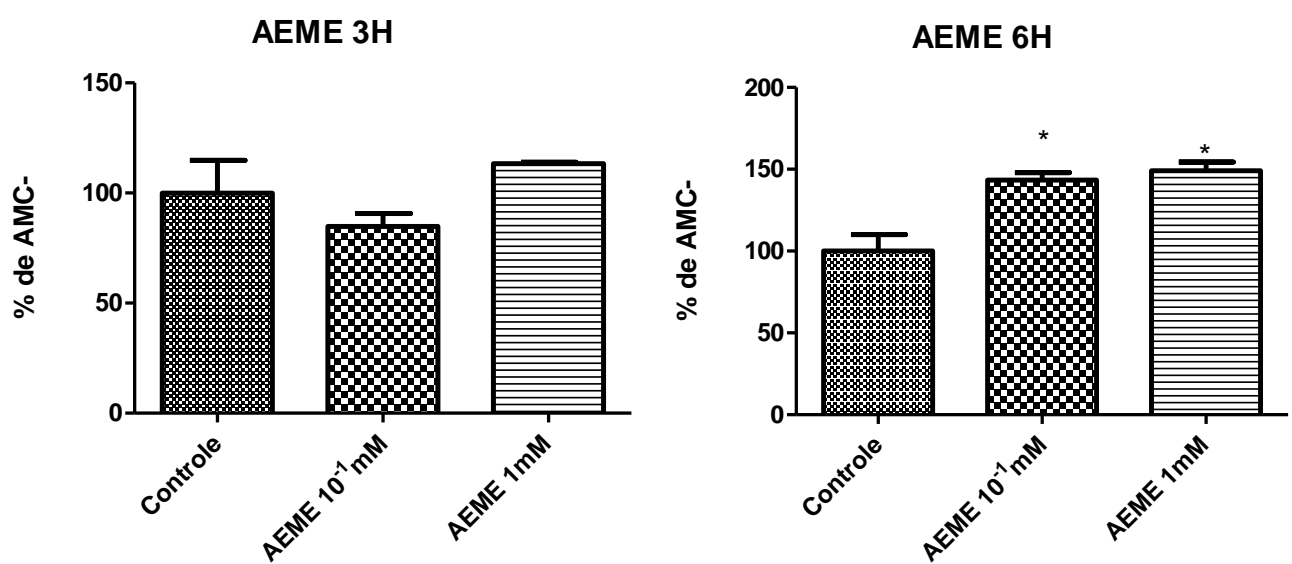

Figura 29. Resultados dos ensaios da atividade da caspase- 3 em neurônios $(n=4)$. Exposição à AEME por 3 e 6 horas. CTRL = controle, $A E M E=$ metilecgonidina. ${ }^{*} p<0,05$ (comparação do grupo tratado com o controle); (ANOVA e comparação múltipla de Newman-Keuls).

Houve um aumento na atividade da caspase-3 após 3 horas de incubação com cocaína na concentração de $1 \mathrm{mM}(p<0,01)$ em relação ao controle. A concentração de $2 \mathrm{mM}$ não estimulou a atividade dessa enzima. Após 6 horas de incubação com cocaína, foi observado aumento na atividade da caspase-3 apenas na concentração de $1 \mathrm{mM}(p<0,01)$ (Figura 30). 

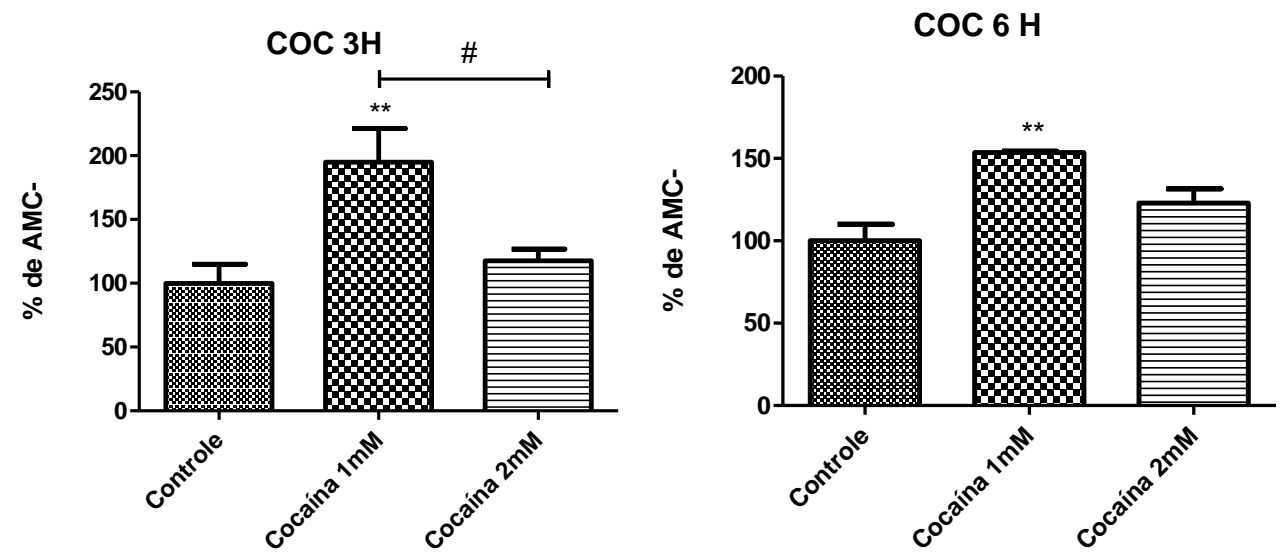

Figura 30. Resultados dos ensaios da atividade da caspase- 3 em neurônios $(n=4)$. Exposição à cocaína por 3 e 6 horas. CTRL $=$ controle, COC = cocaína. ${ }^{* *} p<0,01$ (comparação do grupo tratado com o controle); ${ }^{\sharp} p<0,05$; (diferença em relação aos grupos tratados) (ANOVA e comparação múltipla de Newman-Keuls).

Em contrapartida, quando os neurônios foram incubados por 3 horas com a associação (AEME $1 \mathrm{mM}$ /cocaína $2 \mathrm{mM}$ ), não houve aumento da atividade da caspase-3. Já quando a incubação foi por 6 horas, o grupo da associação (AEME $1 \mathrm{mM}$ /cocaína $2 \mathrm{mM}$ ) apresentou uma diminuição na atividade da caspase-3 em relação ao controle $(p<0,05)$ e em relação aos grupos isolados (AEME $p<0,01$ e cocaína $p<0,05$ ) (Figura 31). 

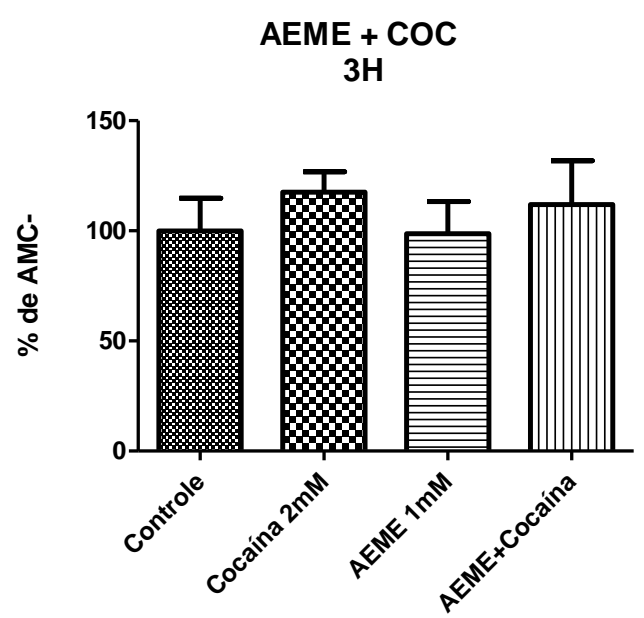

AEME + COC

$6 \mathrm{H}$

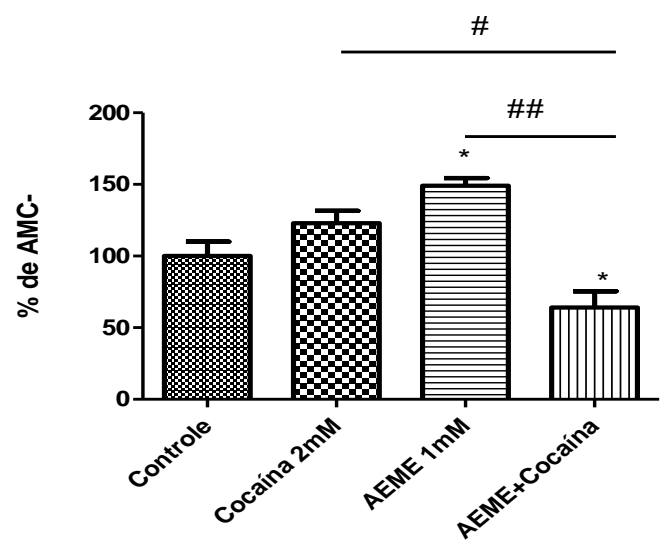

Figura 31. Resultados dos ensaios da atividade da caspase- 3 em neurônios $(n=4)$. Exposição à AEME, à cocaína e à associação (AEME $1 \mathrm{mM} /$ cocaína $2 \mathrm{mM}$ ) por 3 e 6 horas. CTRL = controle, $\mathrm{COC}=$ cocaína, $\mathrm{AEME}=$ metilecgonidina. ${ }^{*} p<0,05$ (comparação do grupo tratado com $o$ controle); ${ }^{p} p<0,05 ;{ }^{\#} p<0,01$ (diferença em relação aos grupos tratados) (ANOVA $e$ comparação múltipla de Newman-Keuls). 
6. DISCUSSÃO 
O uso da cocaína induz efeitos que alteram a fisiologia de diversos sistemas, tais como: cardiovascular, respiratório e SNC (OMS, 2007). O usuário do crack sofre ação não só com os efeitos da cocaína, mas dos produtos de sua pirólise, fator que leva os usuários do crack a terem efeitos mais rápidos dos que são encontrados nos usuários de cocaína, como consequência tem a "fissura" mais intensa, ou seja o desejo cada vez maior pelo uso, já que os efeitos prazerosos do crack são muito rápidos e intensos. No entanto, poucas são as informações a respeito dos efeitos das substâncias produzidas durante o fumo de crack.

Uma vez que o usuário de crack sofre os efeitos tanto da cocaína quanto de seu produto de pirólise, aliado aos resultados de estudos prévios de nosso grupo que já apontaram que a AEME possui propriedades neurotóxicas, este estudo teve como objetivo avaliar o mecanismo de ação da AEME, assim como os possíveis mecanismos envolvidos na morte neuronal.

Para melhor entendimento dos resultados deste trabalho, a discussão foi dividida em duas etapas: uma contemplando o envolvimento das substâncias em estudo com os receptores muscarínicos; e outra abordando as vias de morte celular, com objetivo de caracterizá-las para cada substância em estudo utilizando a cultura neuronal de hipocampo.

\subsection{AEME, COCAÍNA E ASSOCIAÇÃO (AEME $1 \mathrm{mM} /$ cocaína $2 \mathrm{mM}$ ) E RECEPTORES MUSCARÍNICOS}

Para avaliar o envolvimento da AEME com os receptores muscarínicos, os neurônios foram incubados com a atropina um antagonista inespecífico de receptor muscarínico, juntamente com a substância de interesse. Os resultados 
mostraram que a atropina foi capaz de proteger os neurônios da ação da AEME de forma significativa. Este efeito reforça que a AEME interage com receptores mucarínicos no SNC, especificamente no hipocampo, região envolvida no aprendizado e memória.

A ação muscarínica da AEME já havia sido evidenciada no sistema cardiovascular em coelhos por ERZOUKI et al. (1995). Estes autores verificaram que a $A E M E$, provoca uma diminuição na pressão arterial, juntamente com os batimentos cardíacos, evidenciando sua ação muscarínica. Outros trabalhos também destacaram a ação muscarínica da AEME no sistema periférico, como o trabalho de SCHEIDWEILER et al. (2003) que mostrou que a AEME induziu taquicardia e hipotensão reflexa em ovelhas, sendo esse efeito revertido após a administração de atropina. Mais ainda, HUANG et al. (1997), observaram diminuição da contração das fibras musculares em cardiomiócitos. Um mecanismo que explica essa ação é a ativação de receptores muscarínicos do subtipo $\mathrm{M}_{2}$, que leva à diminuição na concentração intracelular de cálcio. Assim sendo, nosso estudo foi o primeiro a sugerir uma ação muscarínica da AEME no SNC.

Trabalho anterior de nosso grupo realizado por GARCIA et al. (2012), evidenciou, por meio de ensaio de competição, a ligação da AEME com receptores muscarínicos no hipocampo. Durante este ensaio, verificou-se que a constante de inibição (Ki) obtida para a AEME era semelhante à arecolina, uma substância definida como agonista muscarínico e que se assemelha, estruturalmente, à AEME (Figura 33). O valor de pKi da AEME $(4,15 \pm 0,15)$ é próximo aos valores obtidos para a arecolina: 4,55 $\pm 0,15\left(\mathrm{M}_{1}\right) ; 4,75 \pm 0,18$ $\left(\mathrm{M}_{2}\right) ; 4,11 \pm 0,14\left(\mathrm{M}_{3}\right) ; 4,14 \pm 0,11\left(\mathrm{M}_{4}\right)$ e 4,83 \pm 0,12( $\left.\mathrm{M}_{5}\right)(\mathrm{DONG}$ et al., 1995; 
GARCIA et al., 2012). Essa proximidade de valores é sugestiva de uma possível ação agonista da AEME em receptores colinérgicos muscarínicos.

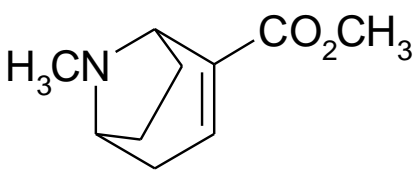

AEME

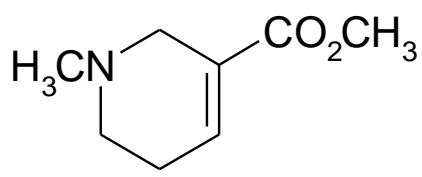

Arecolina

Figura 32. Semelhança estrutural entre AEME e arecolina.

Uma vez que, a via intracelular desencadeada pela ativação de receptores muscarínicos dos subtipos $M_{1}, M_{3}$ e $M_{5}$, os quais são acoplados à proteína $\mathrm{Gq}$, levam à formação de $\mathrm{IP}_{3}$ e aumento na liberação de cálcio (SCHELL \& IRVINE, 2006), nossa etapa seguinte foi verificar a formação destes segundos mensageiros pela AEME. Nossos resultados indicaram que a AEME foi capaz de estimular a formação de $\operatorname{IP}_{3}$ e, posteriormente, aumentar a concentração de cálcio intracelular, reforçando a ação da AEME nos subtipos de receptor muscarínico $M_{1}, M_{3}$ e $M_{5}$.

Complementando estes resultados, trabalho realizado por MESQUITA, 2012, mostrou que a AEME, em cultura de pinealócito, não diminuiu a formação de AMPc, sugerindo que a AEME, pelo menos nessas células, não estimulou as vias intracelulares acopladas a proteína Gi, ou seja, não se ligou aos receptores muscarínicos subtipos $\mathrm{M}_{2}$ e $\mathrm{M}_{4}$. Desta forma, pode-se propor que a $A E M E$ interage em receptores muscarínicos subtipos $M_{1}, M_{3}$ e $M_{5}$, no hipocampo.

Não foi observada ação da atropina na morte neuronal causada pela cocaína e pela associação (AEME $1 \mathrm{mM}$ /cocaína $2 \mathrm{mM}$ ). De acordo com diversos autores, a cocaína possui ação em receptor colinérgico muscarínico 
no SNC (WILLIAMS \& ADINOFF, 2008; ADINOFF et al., 2010; FLYNN et al., 1992; SHARKEY et al., 1988), sendo que os principais subtipos de receptor muscarínico envolvidos são os $\mathrm{M}_{1}$ e $\mathrm{M}_{2}$.

Um dado interessante é o relato de que a cocaína teria afinidade por receptores muscarínicos do subtipo $M_{5}$ (RAFFA, 2009). Embora esse subtipo esteja presente no hipocampo, CARDOSO et al. (2010) mostraram que a expressão dos subtipos muscarínicos nessa região encefálica decresce na seguinte ordem: $M_{1}>M_{2}>M_{3}=M_{4}>M_{5}$.

Diante destas informações, uma provável explicação para a falta de efeito da atropina na viabilidade neuronal, no caso da exposição concomitante com a associação (AEME $1 \mathrm{mM}$ /cocaína $2 \mathrm{mM}$ ), é que a ação da cocaína prevaleça em relação à ação da AEME.

Vale a pena destacar que, conforme será visto no próximo item, a cocaína leva à morte neuronal por diversas vias. Assim sendo, apesar de ADINOFF et al. (2010), ter demonstrado que a cocaína tem afinidade pelos receptores muscarínicos no SNC. Os resultados do nosso trabalho utilizando cultura primária de hipocampo, sugerem que este mecanismo teria participação mínima no mecanismo de neurotoxicidade.

\subsection{VIAS DE MORTE NEURONAL}

O primeiro trabalho a avaliar a ação da AEME no SNC foi o de GARCIA et al. (2012). Neste estudo, foi sugerido que a AEME induz morte neuronal principalmente estimulando vias de apoptose. Nossos resultados corroboram esses dados iniciais, uma vez que a AEME, após 24 horas de incubação em células neuronais, levou a um aumento na fragmentação do DNA. Além deste 
primeiro indício de apoptose, foi encontrado um desbalanço na expressão de proteínas mitocondriais pró e antiapoptóticas, com aumento da proteína Bax, que desempenha função pró-apoptótica, após 3 horas de incubação. Outra via estimulada pela AEME é a da caspase-3, cujo aumento de sua atividade foi encontrado após 6 horas de incubação.

O envolvimento da via da Bax induz a perda da integridade mitocondrial e, consequentemente, da liberação de citocromo $c$ para o citosol, o que induz a ativação da caspase-9 estimulando a cascata das caspases, finalizando na ativação da caspase-3. Assim, levando-se em consideração os resultados deste trabalho, pode-se sugerir que a AEME, após 3 horas de incubação, estimula a morte neuronal por meio da ativação das vias apoptóticas, envolvendo proteínas mitocondriais e a via da caspase-3. Neurotoxicidade de agonista muscarínico foi descrita por SHIH et al. (2010), que avaliaram os efeitos da arecolina em cultura primária de córtex. A arecolina estimulou a expressão de proteínas mitocondriais Bax/Bcl-2 e, como consequência, ativou a via das caspases aumentando a atividade da caspase-3, levando à morte neuronal. Estes resultados indicam que a AEME e a arecolina apresentam, além da semelhança na estrutura química, vias de morte neuronal semelhantes no SNC.

Foi observado uma alteração do mecanismo de morte neuronal com o aumento do tempo de incubação com AEME. Após 24 horas de incubação, os neurônios perderam a integridade da membrana celular, indício de morte celular por necrose. Este dado sugere que, após este período de incubação, os neurônios podem estimular vias de morte celular tanto envolvendo apoptose quanto necrose. 
Outra ação importante da AEME foi a indução do aumento de cálcio intracelular. O cálcio é importante para a manutenção e o desenvolvimento neuronal. Contudo, seu aumento, além do fisiológico nos neurônios, induz a despolarização mitocondrial e aumenta as vias de sinalização reguladas pelo cálcio como, por exemplo, a proteína quinase cálcio/calmodulina, que fosforila diversos substratos neuronais como os canais para cálcio e, por consequência, canais para potássio (ASHPOLE et al., 2012). Mais estudos são necessários, como a análise do potencial da membrana mitocondrial, liberação de citocromo c, de outras proteínas mitocondriais (Bad, Bid, IAPs) e de fatores de transcrição como o p53, para que possa elucidar totalmente as vias pelas quais a AEME induz neurotoxicidade.

$\mathrm{Na}$ figura 34 representa a sinalização de morte neuronal induzida pela AEME em cultura primária de hipocampo. 


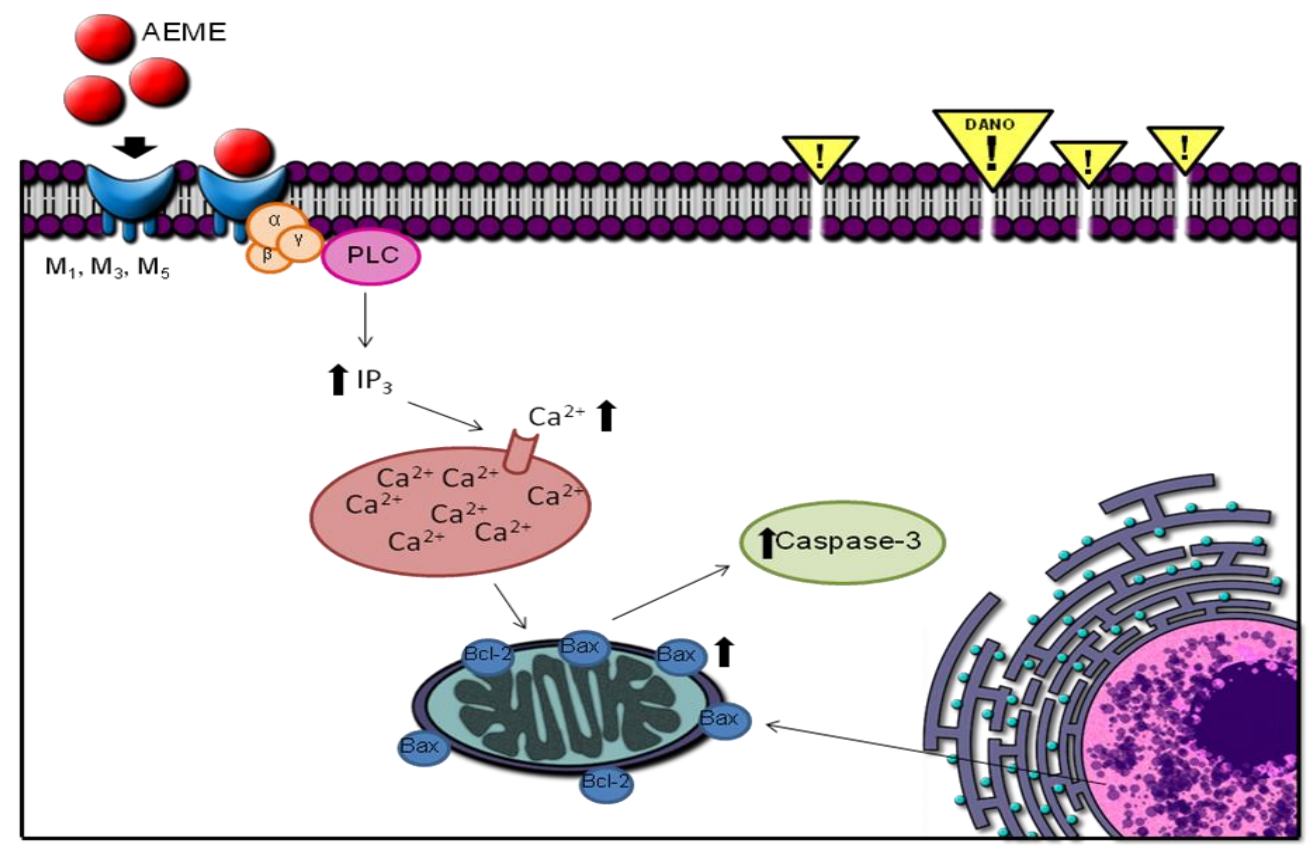

Figura 33. Sinalização intracelular induzida pela AEME em cultura primária de hipocampo, mostrando a interação da AEME com receptores colinérgicos muscarínicos, principalmente os subtipos $M_{1}, M_{3}, M_{5}$. Esses subtipos estimulam a formação de $\mathbb{I P}_{3}$, aumentando a concentração de cálcio intracelular. Além desta ação, ainda foi observado que a AEME age em proteínas mitocondriais (Bax/Bcl-2) e na ativação da caspase-3, promovendo a fragmentação do DNA e o rompimento da membrana neuronal.

Apesar de não interagir com receptor colinérgico muscarínico em nosso modelo de estudo, a cocaína apresentou um aumento de cálcio intracelular. 0 aumento de cálcio intracelular também foi encontrado no trabalho de CUNHAOLIVEIRA et al. (2010), em cultura de neurônios corticais os quais mostraram que o aumento de cálcio intracelular ocorreu devido à abertura dos canais de cálcio, induzindo a despolarização da membrana celular. Estas modificações intracelulares desencadeiam disfunção mitocondrial, acarretando alteração na cadeia de transporte de elétrons (CUNHA-OLIVEIRA et al., 2006). Vale destacar que todas estas mudanças levam à diminuição nos níveis de ATP, o que induz a ativação de caspases como a caspase-2, caspase-9 e caspase-3 desencadeando, desta forma, a morte neuronal.

A ativação da via das caspases pela cocaína já foi previamente relatada. Trabalhos de CUNHA-OLIVEIRA et al. (2008 e 2010) mostraram que a cocaína 
estimula a atividade de caspase- 3 em células neuronais do córtex. Este estímulo ocorreu na concentração de $1 \mathrm{mM}$ e quando incubado por 3 horas. Além disso, LEPSCH et al. (2009) demonstraram, em células PC12, um aumento da atividade da caspase-3 após a incubação com cocaína $1 \mathrm{mM}$ por 6 horas. As concentrações utilizadas neste trabalho foram baseadas em diversos trabalhos científicos (CUNHA-OLIVEIRA et al., 2010; IMAM et al., 2005; YUAN \& ACOSTA, 2000; ZARAGOZA et al., 2001) e variaram de 50 a $2500 \mu \mathrm{M}$ em diversos modelos de cultura de células, tais como em células do miocárdio, hepatócitos e células PC12. Apesar da inervação predominantemente colinérgica presente no hipocampo, há algumas inervações dopaminérgicas eferentes da substância negra e da área tegmental ventral (OTMAKHOVA \& LISMAN, 1996). Estas inervações dopaminérgicas em neurônios colinérgicos podem justificar a neurotoxicidade causada pela cocaína nas células hipocampais, uma vez que há produção de metabólitos da dopamina que aumentam o número de espécies reativas de oxigênio (DIETRICH et al., 2005; POON et al., 2007). No entanto, a concentração de cocaína necessária para observar sua neurotoxicidade teve que ser aumentada, conforme descrito por GARCIA et al. (2012).

DEY et al. (2007) mostraram que a cocaína estimula vias apoptóticas em cultura de células neuronais do locus ceruleos e da substância negra. Este trabalho mostrou que a cocaína $(1,5 \mu \mathrm{M})$ induz morte por apoptose, após a incubação por 30 e 60 minutos, principalmente pela indução da liberação de Bax, estimulando a liberação de citocromo c e a ativação da cascata das caspases. Nossos resultados mostraram algumas alterações na expressão das proteínas Bax e Bcl-2 nos diferentes períodos de incubação e concentrações 
estudadas. De acordo com XIAO \& ZHANG (2008), o aumento da Bcl-2 pode estar relacionado à tentativa de reverter a morte celular. Contudo, somente a partir da razão $\mathrm{Bax} / \mathrm{Bcl}-2$ é possível avaliar se as células estão desencadeando o processo de morte ou se estão estimulando a expressão da proteína na intenção de manter a célula viva por mais tempo. Em todos os casos observados no presente estudo com relação à cocaína, não houve alteração na razão $\mathrm{Bax} / \mathrm{Bcl}-2$, sugerindo que as alterações encontradas não causaram desbalanço entre as duas proteínas. Esses resultados corroboram com os da fragmentação de DNA, onde observamos aumento nesse processo somente com a concentração mais alta de cocaína (2 mM), após 12 horas de incubação. Quando os neurônios foram incubados por 24 horas, a fragmentação de DNA ocorreu nas duas concentrações testadas ( 1 e $2 \mathrm{mM}$ ), sendo maior na concentração de $2 \mathrm{mM}$, indicando que quanto maior a concentração maior a quantidade de DNA fragmentado.

Mesmo não estimulando a expressão de proteínas mitocondriais, foi encontrado ativação da caspase-3, processo que pode ocorrer por outras vias, além da ativação de Bax/Bcl-2, como por exemplo, a da ativação de receptores de morte neuronal (Fas/Fas-I) que, quando ativados, induzem a ativação da cascata das caspases, neste caso a caspase-8, culminando com a ativação da caspase-3.

Por outro lado quando os neurônios foram incubados por 24 horas, houve perda da integridade da membrana plasmática, indícios de que as células estão em necrose, uma vez que este processo é clássico para este tipo de morte. 
Desta forma, podemos sugerir que, após 24 horas de incubação, os neurônios ativam vias de morte celular tanto de apoptose quanto de necrose, resultados que vão de acordo com trabalho de GARCIA et al. (2012), os quais mostraram um aumento de LDH (indício de necrose) e morte celular por perda de atividade mitocondrial (indício de apoptose).

A figura 35 representa a ação da cocaína em cultura primária de hipocampo. Foram destacadas as vias de morte neuronal tanto por apoptose quanto por necrose estudada neste trabalho.

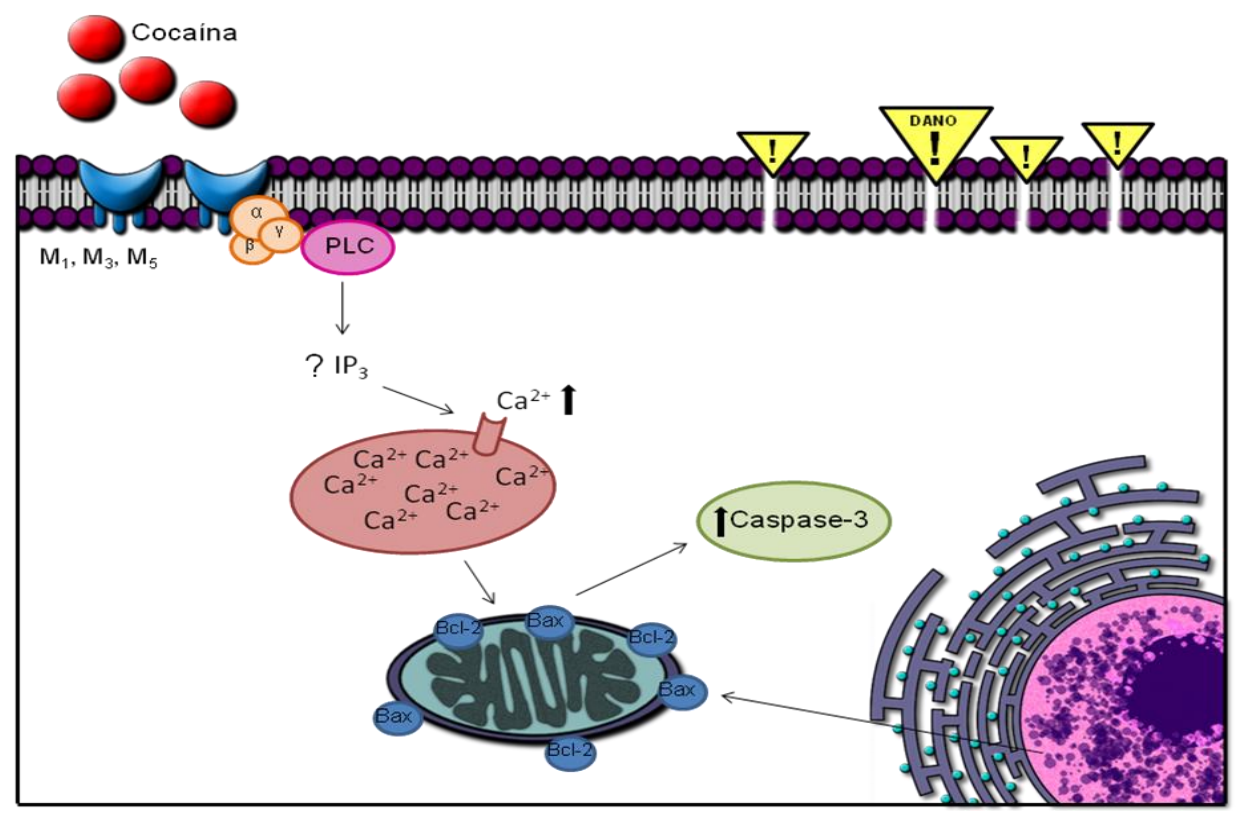

Figura 34. Sinalização intracelular estimulada pela cocaína. Esta parece não interagir com receptores colinérgicos muscarínicos em cultura primária de hipocampo. Apesar de não induzir a expressão de proteínas mitocondriais (Bax/Bcl-2), a cocaína aumentou a atividade da caspase-3, a concentração de cálcio intracelular, a fragmentação de DNA e a perda da integridade da membrana celular.

Resultados interessantes foram observados com a associação (AEME 1 mM /cocaína $2 \mathrm{mM}$ ). Diferente do observado com cocaína e AEME individualmente, houve diminuição da atividade da caspase-3 em neurônios hipocampais incubados por 6 horas com a associação (AEME $1 \mathrm{mM}$ /cocaína 2 mM). De acordo com SEO et al. (2009), a diminuição da caspase-3 indica que 
ocorreu uma troca no padrão de morte celular. Quando há ativação da caspase-3, sugere-se morte celular por apoptose, enquanto que, quando há uma diminuição da caspase-3, é provável que as células estejam inibindo a liberação de citocromo c e a expressão das proteínas mitocondriais como o caso da Bax, desencadeando na sinalização para morte celular por necrose. Observamos uma diminuição da expressão da proteína mitocondrial Bcl-2, sem alteração da Bax, com a associação (AEME $1 \mathrm{mM}$ / cocaína $2 \mathrm{mM}$ ) após 3 e 6 horas de incubação. Porém, só houve alteração da razão $\mathrm{Bax} / \mathrm{Bcl}-2$ após 6 horas de incubação, provavelmente devido à redução da expressão da proteína Bcl-2. Ll et al. (2005) mostraram que a cocaína induz a diminuição da expressão da proteína Bcl-2 em cultura de cardiomiócitos sem a alteração da proteína Bax. Estes autores sugerem que os efeitos desencadeados nesta célula podem estar relacionados com a ativação da proteína quinase p38 MAPK, a qual estimula a liberação de citocromo $c$, independentemente da expressão destas proteínas pró-apoptóticas.

Outro achado importante neste trabalho foi que, no grupo da associação (AEME $1 \mathrm{mM}$ /cocaína $2 \mathrm{mM}$ ), os neurônios apresentam uma perda da integridade da membrana quando incubados por 12 e 24 horas, sugerindo que as células estão em necrose.

Por outro lado, no período de 12 horas, os neurônios apresentaram fragmentação de DNA, indício de que as células estão em apoptose. Quando foram incubados por 24 horas, essa fragmentação foi maior no grupo da associação (AEME $1 \mathrm{mM}$ /cocaína $2 \mathrm{mM}$ ) que no grupo da AEME, mas foi bem semelhante ao grupo da cocaína. O envolvimento de duplo processo de morte neuronal já foi descrito por LEPSCH et al. (2009) que mostraram que em 
células PC12, após 24 horas de incubação com cocaína 1 mM, ocorre indução de morte celular tanto por apoptose quanto por necrose.

Outro dado importante foi o encontrado na avaliação da concentração de cálcio intracelular pela associação (AEME $1 \mathrm{mM}$ /cocaína $2 \mathrm{mM}$ ). Foi observado um aumento de cálcio com a associação, o qual não foi maior significativamente em relação à AEME e cocaína isoladamente, mostrando que não há efeito aditivo decorrente da associação das duas substâncias. 0 aumento do cálcio altera os mecanismos bioquímicos dos neurônios, principalmente na despolarização e na atividade sináptica. Além disso, o aumento de cálcio mobiliza mais energia mitocondrial, consumindo mais ATP e aumentando a geração de espécies reativas de oxigênio na mitocôndria (GLEICHMANN \& MATTSON, 2011).

Assim, observamos que as vias de morte neuronal induzidas pela associação (AEME $1 \mathrm{mM}$ /cocaína $2 \mathrm{mM}$ ) envolvem tanto apoptose quanto necrose.

A figura 36 representa um resumo das vias estudadas neste trabalho de morte neuronal estimuladas pela associação (AEME $1 \mathrm{mM}$ /cocaína $2 \mathrm{mM}$ ). As vias são típicas para morte neuronal para apoptose e necrose. 


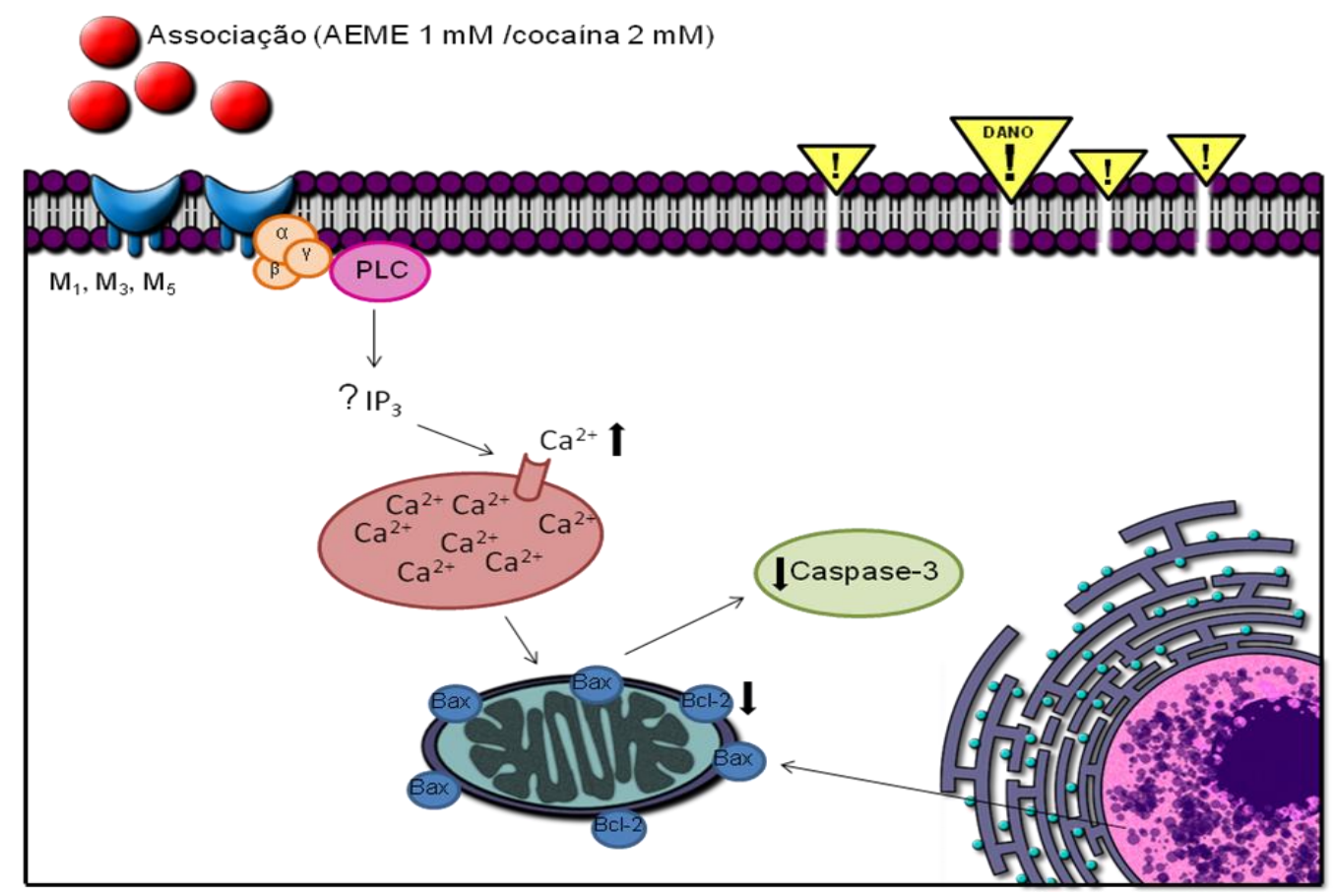

Figura 35. Sinalização intracelular induzida pela associação (AEME $1 \mathrm{mM}$ /cocaína $2 \mathrm{mM}$ ). Apesar de não interagir com receptores colinérgicos muscarínicos, houve aumento da concentração de cálcio intracelular. Além disso, houve aumento da razão das proteínas mitocondriais (Bax/Bcl-2), diminuição da atividade da caspase-3, estimulação da fragmentação do DNA e perda da integridade da membrana celular dos neurônios. 
7. CONCLUSÃO 
Os resultados deste trabalho, avaliado em cultura primária de hipocampo, nos permite concluir que:

- A AEME interage com receptores colinérgicos muscarínicos estimulando vias do $\mathrm{IP}_{3}$ e cálcio intracelular, sugerindo a ligação aos subtipos $M_{1}, M_{3}$ e $\mathrm{M}_{5}$.

- A atropina foi capaz de prevenir a morte neuronal induzida pela AEME, porém não foi capaz de proteger os neurônios quando incubados com a cocaína e com a associação (AEME $1 \mathrm{mM}$ /cocaína $2 \mathrm{mM}$ ), sugerindo que a via de morte neuronal, desencadeadas nesses dois últimos casos, parece ser independente dos receptores colinérgicos muscarínicos.

- A exposição à $\mathrm{AEME}$ por curto período de tempo leva à morte neuronal por apoptose por meio da ativação de proteínas mitocondriais (Bax/Bcl2) e, consequentemente, da caspase-3. Após 24 horas de exposição, os neurônios apresentaram fragmentação de DNA e perda da integridade da membrana celular, indício de morte neuronal por apoptose e necrose, respectivamente.

- A via de morte neuronal ativada pela cocaína também se mostrou dependente do tempo de incubação. Após 12 e 24 horas de exposição, foi observada fragmentação do DNA e, após 3 e 6 horas, houve aumento da atividade da caspase-3, sugerindo a via apoptótica. Entretanto, após 24 horas de incubação, os neurônios perderam a 
integridade da membrana celular, indicando a morte neuronal também por necrose. A concentração de cálcio intracelular foi dose-dependente quando os neurônios foram incubados com cocaína, estando envolvida nos dois mecanismos de morte neuronal.

- A exposição à associação (AEME $1 \mathrm{mM}$ /cocaína 2 mM) após 12 e 24 horas induziu tanto à fragmentação do DNA quanto à perda da integridade da membrana celular, sugerindo morte neuronal por apoptose e necrose, respectivamente. Mais ainda, foi observada diferença na razão da expressão das proteínas mitocondriais Bax/Bcl-2 após 6 horas de incubação, sugerindo que o mecanismo de morte neuronal inicial é a apoptose, evoluindo para necrose com o aumento do tempo de exposição. Esse dado é corroborado pela diminuição da atividade da caspase-3 após 6 horas de incubação, indício de morte celular por necrose. Estes mecanismos parecem também ser mediados pelo aumento de cálcio intracelular. 


\section{REFERÊNCIAS BIBLIOGRÁFICAS}


ABDALLA. F.M.F.; ABREU. L.C.; PORTO. C.S. Effect of estrogen on intracellular signaling pathways linked to activation of M2- and M3-muscarinic acetylcholine receptors in the rat myometrium. Mol Cell Endocrinol. V. 160:17-24, 2000.

ABE, K.; SAITO, H. Both oxidative stress-dependent and independent effects of amyloid $\beta$ protein are detected by (3-4,5-dimethylthiazol-2-yl)-2,5-diphenyltetrazolium bromide (MTT) reduction assay. Brain Research, v. 830:146-154, 1999.

ADINOFF, B.; DEVOUS, M. D.; WILLIAMS, M. J.; BEST, S. E.; HARRIS, T. S.; MINHAJUDDIN, A.; ZIELINSKI, T.; CULLUM, M. Altered neural cholinergic receptor systems in cocaine-addicted subjects. Neuropsychopharmacology., v.35: 1485-1499, 2010.

ALBERTS B.; JOHNSON A.; LEWIS J.; RAFF M.; ROBERTS K.; WALTER P. Molecular biology of the cell. Garland Science Taylor \& Francis Group, 4ํeㄹção, caps: 15 (pags. 831-906) e 17(pags. 983-1026), New York, 2002.

ALKONDON, M.; ALBUQUERQUE, E. X. Nicotinic acetylcholine receptor alpha 7 and alpha4beta2 subtypesdifferentialy control GABAergic input to CA1 neurons in rat hippocampus. J. Neurophysiol., v. 86: 3943-55, 2002.

AMARAL, D. G. A Golgistudy of cell types in the hilar region of the hippocampus in the rat. J. Comp. Neurol., 15:851-914, 1978.

AMARAL, D.; LAVENEX, P. Hippocampal Neuroanatomy. In: P. ANDERSEN; R. MORRIS; D. AMARAL; T. BLISS; J. O'KEEFE (Eds.). The Hippocampus Book. Oxford University Press (Oxford), 37-144, 2007. 
ARACAVA, Y.; DESHPANDE, S. S.; SWANSON, K. L.; RAPOPORT, H.; WONNACOTT, S.; LUNT, G.; ALBUQUERQUE, E. X. Nicotinic acetylcholine receptors in cultured neurons from the hippocampus and brain stem of the rat characterized by single channel recording. FEBS Lett., v. $222(1): 63-70,1987$.

ASCOLI. M.; PIGNATARO. O.P.; SEGALOFF. D.L. The inositol phosphate/diacyglycerol pathway in MA-10 Leydig tumor cells. Activation by arginine vasopressin and lack of effect of epidermal growth factor and human choriogonadotropin. J Biol Chem. V. 264:6674-6681, 1989.

ASHPOLE, N. M.; SONG, W.; BRUSTOVETSKY, T.; ENGLEMAN, E. A.; BRUSTOVETSKY, N.; CUMMINS, T. R.; HUDMON, A. Calcium/calmodulin-dependent protein kinases II (CaMKII) inhibition induces neurotoxicity via dysregulation of glutamate/calcium signaling and hyperexcitability. The Journal of Biological Chemistry., v. 287 (11): 8495-8506, 2012.

BAN, J. Y.; JEON, S. Y.; NGUYEN, T. T. H.; BAE, K.; SONG K. S.; SEONG, Y. H. Neuroprotective effect of oxyresveratrol from Smilacis Chinae rhizome on amyloid B protein (2535)- induced neurotoxicity in cultured rat cortical neurons. Biol. Pharm Bull., v. 29 (12): 24192424, 2006.

BANKER, G. A.; COWAN, W. M. Rat hippocampal neurons in dispersed cell culture. Brain Research, v. 126(3):397-42, 1977.

BergantinI, A. P. F.; CAStRo, F. A.; SOUZA, A. M.; FeTt-CONTE, A. C. Leucemia mielóide crônica e o sistema Faz-FasL. Rev. Bras. Hematol. Hemoter., v. 27(2): 120-125, 2005. 
BOGHDADI, M. S.; HENNING, R. J. Cocaine: athophysiology and clinical toxicology. Heart and Lung., v. 26:466-83, 1997.

BRADFORD, M. A rapid and sensitive method for the quantification of microgram quantities of protein utilizing the principle of protein-dry bending. Anal Biochem. v. 72: 248-254, 1976.

BURSTEIN, E. S.; SPALDING, T. A.; BRANN, M. R. The second intracellular loop of the M5 muscarinic receptor is the switch which enables G-protein coupling. J. Biological Chemistry., v. 273 (38): 24322-24327, 1998.

CARDOSO, C. C.; RICARDO, V. P.; FRUSSA-FILHO, R.; PORTO, C. S.; ABDALLA, F. M. Efectes of $17 \beta$-estradiol on expression of muscarinic acetylcholine receptor subtypes and estroggen receptor alpha in rat hippocampus. Eur. J. Pharmacol., v. 25:192-200, 2010.

CAULFIELD, M. P. \& BIRDSALL, N. J. M. Classification of muscarinic acetylcholine receptors. Pharmacol. Rev., v. 50:279-290, 1998.

CEBRID - Centro Brasileiro de Informações sobre Drogas Psicotrópicas: http://www.cebrid.epm.br/index.php, 2001.

CEBRID - Centro Brasileiro de Informações sobre Drogas Psicotrópicas: http://www.cebrid.epm.br/index.php, 2003.

CEBRID - Centro Brasileiro de Informações sobre Drogas Psicotrópicas: http://www.cebrid.epm.br/index.php, 2005.

CHASIN, A. A. M. \& MIDIO, A. F. Cocaína como agente de causa mortis. Revista Saúde, Ética e Justiça, v. 2 (1):47-59, 1997. 
CHASIN, A. A. M.; SILVA, E. S.; CARVALHO, V. M. Estimulantes do Sistema Nervoso Central. In: S. OGA; M. M. A. CAMARGO; J. A. O. BATISTUZZO (Eds.). Fundamentos de Toxicologia, 3 ed., Atheneu (SP), 353-373, 2008.

Cocaine and Crack cocaine: a Growing public health issue; European Monitoring Center for Drugs and Drugs Addiction. Organização Mundial da Saúde., 2007.

CRITS-CHRISTOPH, P.; GIBBONS, M. B. C.; RING-KURTZ, S.; GALLOP, R.; PRESENT, J. A pilot study of community-friendly manual-guided drug counseling. Journal of Substance Abuse Treatment. P. 1-9, 2009.

CUNHA-OLIVEIRA, T.; REGO, A. C.; CARDOSO, S. M.; BORGES, F.; SWERDLOW, R. H.; MACEDO, T.; OLIVEIRA, C. R. Mitochondrial dysfunction and caspase activation in rat cortical neurons treated with cocaine or amphetamine. Brain Research., v. 1089:44-54, 2006.

CUNHA-OLIVEIRA, T.; REGO, A. C.; OLIVEIRA, C. R. Cellular and molecular mechanisms involved in the neurotixicity of opioid and psychostimulant drugs. Brain Research Reviews., v. 58:192-208, 2008.

CUNHA-OLIVEIRA, T.; REGO, A. C.; GARRIDO, J.; BORGES, F.; MACEDO, T.; OLIVEIRA, C. R. Neutoxicity of heroin-cocaine combinations in rat cortical neurons. Toxicology., v. 276:1117, 2010.

CUNHA, P. J.; NICASTRI, S.; GOMES, L. P.; MOINO, R. M.; PELUSO, M. A. Neuropsychological impairments in crack cocaine-dependent inpatients: preliminary findings. Rev. Bras. Psiquiatr., v. 26 (2):103-6, 2004. 
CURTIN, J. F.; DOROVAN, M.; COTTER, T. G. Regulation and measurement of oxidative stress in apoptosis. Mol. Cell. Biol. v. 20: 6008-6018, 2002.

DANIAL, N. K.; KORSMEYER, S. J. Cell death: critical control points (2004). In: G. M. COOPER.; R. E. HAUSMAN. The cell a molecular approach, 4 ed., ASM Press (Washington, D.C.), 689-718, 2007.

DATTA, S. R.; BRUNET, A.; GREENBERG, M. E. Cellular survival: A play in three Akts (1999). In. COOPER, G. M. \& HAUSMAN, R. E. The Cell a molecular approach, 4 ed., ASM Press (Washington, D.C.), 618-619, 2007.

DEL OLMO, N.; MIGUENS, M.; HIGUERA-MATAS, A.; TORRES, I.; GARCIA-LECUMBERRI, C.; SOLIS, J. M.; AMBROSIO, M. Enhancement of hippocampal long-term potentiation induced by cocaine self-administration is maintained during the extinction of this behavior. Brain Research, v. 1116:120-126, 2006.

DESAGHER, S.; MARTINOU, J. C. Mitochondria as the central control point of apoptosis. Trends Cell Biol., v. 10:369-377, 2000.

DEY, S.; MACTUTUS, C. F.; BOOZE, R. M. SNOW, D. M. Cocaine exposure in vitro induces apoptosis in fetal locus coeruleus neurons by altering the Bax/Bcl-2 ratio and through caspase- 3 apoptotoc signaling. Neuroscience., v. 144 (2):509-521, 2007.

DRAGOVICH, T.; RUDIN, C.M.; THOMPSON, C.B. Signal transduction pathways that regulate cell survival and cell death. Oncogene. v. 17:3207-3213, 1998.

DIETRICH, J. B., MANGEOL, A., REVEL, M. O., BURGUN, C., AUNIS, D., ZWILLER, J. Acute or repeated cocaine administration generates reactive oxygen species and induces antioxidant 
enzyme activity in dopaminergic rat brain structures. Neuropharmacology. v. 48, 965-974, 2005.

DONG, G. Z., KAMEYAMA, K., RINKEN, A., HAGA, T. Ligand binding properties of muscarinic acetylcholine receptor subtypes $(\mathrm{m} 1-\mathrm{m} 5)$ expressed in baculovirus-infected insect cells. J. Pharmacol. Exp. Ther. 274, 378-384, 1995.

DUTTAROY, A.; GOMEZA, J.; GAN, J. W.; SIDDIQUI, N.; BASILE, A. S.; HARMAN, W. D.; SMITH, P. L.; FELDER, C. C.; LEVEY, A. I.; WESS, J. Evaluation of muscarinic agonist induced analgesia in muscarinic acetylcholine receptor knockout mice. Mol. Pharmacol., v. 62:10841093, 2002

EGLEN, R. M. Muscarinic receptor subtypes in neuronal and non-neuronal cholinergic function. Autonomic \& Autacoid Pharmacology., v. 26:219-233, 2006.

EHLERT, F. J. Pharmacological analysis of the contractile role M2 and M3 muscarinic receptors in smooth muscle. Receptors Channels., v. 9:261-277, 2003.

ELMORE, S. Apoptosis: A review of programmed cell death. Toxicol Pathol., v.35(4):495-516, 2007.

ERZOUKI, H. K., AlleN, A. C., NeWMAN, A. H., GOldBERG, S. R., SCHINDLER, C. W. Effects of cocaine, cocaine metabolites and cocaine pyrolysis products on the hindbrain cardiac and respiratory centers of the rabbit. Life Sci. v. 57, 1861-1868, 1995. 
FANDIÑO, A. S.; TOENNES, S. W.; KAUERT, G. F. Studies on hydrolytic and oxidative metabolic pathways of anhydroecgonine methyl ester (methylecgonidine) using microssomal preparations from rat organs. Chem. Res. Toxicol., v. 15:1543-1548, 2002.

FANTEL, A. G.; PERSON, R. E. Involvement of mitochondria and other free radicals sources in normal and aabnormal fetal development. Ann NY Acad. Sci., v. 959:424-433, 2002.

FELDER, C. C.; BYMASTER, F. P.; WARD, J. DELAPP, N. Therapeutic opportunities for muscarinic receptors in the central nervous system. J. Med. Chem., v. 43:4333-4353, 2000.

FERREIRA, P. E. M.; MARTINI, R. K. Cocaína: lendas, história e abuso. Rev. Bras. de Psiquiatria. v. 23: 96-99, 2001.

FISAR, Z.; HROUDOVÁ, J. Intracellular signaling pathways and mood disorder. Folia Biologica (Praha)., v. 56: 135-148, 2010.

FLOYD, R. A. Antioxidants, oxidative stress, and degenerative neurological disorders. Proc Soc Exp Biol Med, v. 222:236-245, 1999.

FLYNN, D. D.; VAISHNAV, A. A.; MASH, D. A. Interactions of cocaine with primary and secondary recognition sites on muscarinic receptors. Molecular Pharmacology., v. 41:736$742,1992$. 
FOX. A.W.; ABEL. P.W.; MINNEMAN. K. P. Activation of alpha 1-adrenoceptors increases $[3 \mathrm{H}]$ inositol metabolism in rat vas deferens and caudal artery. Eur. J. Pharmacol. V. 166:145$152,1985$.

FRASER, A.; EVAN, G. A license to kill. Cell. v. 85:781-784, 1996.

GALLUZZI, L.; BLOMGREN, K.; KROEMER, G. Mitochondrial membrane permeabilization in neuronal injury. Nature Review, Neuroscience., v. 10:481-494, 2009.

GARCIA, R. C. T.; DATI, L. M. M.; FUKUDA, S.; TORRE, L. H. L.; MOURA, S.; CARVALHO, N. D.; CARRETTIERO, D. C.; CAMARINI, R.; LEVADA-PIRES, A. C.; YONAMINE, M.; NEGRININETO, O.; ABDALLA, F. M. F.; SANDOVAL, M. R. L.; AFECHE, S. C.; MARCOURAKIS, T. Neurotoxicity of anhydroecgonine methyl ester, a crack cocaine pyrolysis product. Toxicological Science., v. 128: 223-234, 2012.

GIROS, B.; JABER, M.; JONES, S. R.; WIGHTMAN, R. M.; CARON, M. G. Hyperlocomotion and indifference to cocaine and amphetamine in mice lacking the dopamine transporter. Nature., v. 379:606-612, 1996.

GLEICHMANN, M.; MATTSON, M. P. Neuronal calcium homeostasis and dysregulation. Antioxidants \& Redox Signaling.,v. 14: 1261-1273, 2011.

GOTTLIEB, R. A. Role of mitochondria in apoptosis. Crit. Rev. Eukaryot Gen Expr. v.10: 231239, 2000.

GRIVICH, I.; REGNER, A.; ROCHA, A. B. Morte celular por apoptose. Revista Brasileira de Cancerologia. v. 53: 335-343, 2007. 
HALLIWELL, B.; GUTTERIDGE, J. M. C. Free Radicals in Biology and Medicine. Oxford Science Publications. Terceira edição. V. único:105-245, 1999.

HARDINGHAM, G. E.; BADING, H. The yin and yang of NMDA receptor signaling. Trends Neuroscience. v.2: 81-89, 2003.

HENGARTNER, M. O. The biochemistry of apoptosis. Nature., v.407: 770-776, 2000.

HOFMANN, F. The biology of cyclic GMP-dependent protein kinases (2005). In: G. M. COOPER.; R. E. HAUSMAN. The cell a molecular approach, 4 ed., ASM Press (Washington, D.C.), 599-648, 2007.

HUANG, L.; WOOLF, J. H.; ISHIGURO, Y.; MORGAN, J. P. Effect of cocaine and methylecgonidine on intracellular $\mathrm{Ca}_{2+}$ and myocardial contraction in cardiac myocytes. $\mathbf{A m}$. J. Physiol., v. 273:893-901, 1997.

HUETTNER, J. E.; BAUGHMAN, R. W. Primary culture of identified neurons from the visual cortex of postnatal rats. J. Neurosc., v. 6:3044-3060, 1986.

IMAM, S. Z.; DUHART, H. M.; SKINNER, J. T.; ALI, S.F. Cocaine induces a differential dosedependent alteration in the expression profile of immediate early genes, transcription factors, and caspases in PC12 cells: a possible mechanism of neurotoxic damage in cocaine addiction. Ann NY Acad Sci, v. 1053:482-90, 2005.

IOUDINA, M.; UEMURA, E. GREENLEE, H. W. Glucose insufficiency alters neuronal viability and increases susceptibility to glutamate toxicity. Brain Research, v. 1004:188-192, 2004. 
JACOB, P. III., LEWIS, E. R., ELIAS-BAKER, B. A., JONES, R. T. A pyrolysis product, anhydroecgonine methyl ester (methylecgonidine), is in the urine of cocaine smokers. Journal of Analytical Toxicology, v.14:353-357, 1990.

JACOBSON, M. D.; WEIL, M.; RAFF, M. C. Programmed cell death in animal development (2004). In: G. M. COOPER.; R. E. HAUSMAN. The cell a molecular approach, 4 ed., ASM Press (Washington, D.C.), 689-718, 2007.

JAHR, C. E.; STEVENS, C. F. Glutamate activates multiple single channel conductances in hippocampal neurons. Nature, v. 325(6104):522-5, 1989.

JULIEN, R. M. A primer of drug action: a concise, nontechnical guide to the actions, uses and side effects of psychoactive drugs. 7ed. New York: W. H. Freeman, 125-143, 1997.

KENDER, R. G.; HARTE, S. E.; MUNN, E. M.; BORSZCZ, G. S. Affective analgesia following muscarinic activation of the ventral tegmental area in rats. J. Pain., v. 9 (7):597-605, 2008.

KIMLICKA, L. \& PETEGEM, F. V. The structural biology of ryanodine receptors. Science China., v. 54(8):712-724, 2011.

KLINE, R. H.; WRIGTH, J.; FOX, K. M.; ELDEFRAWI, M. E. Synthesis of 3- Arylecgonine Analogues as Inhibitors of Cocaine Binding and Dopamine Uptake. J. Med. Chem., v. 33, 20242027, 1989.

KUIDA, K.; ZHENG, T. S.; NA, S.; KUAN, C.; YANG, D.; KARASUYAMA, H.; RAKIC, P.; FLAVILL, R. A. Decreased apoptosis in the brain and premature lethality in CPP32-deficient mice. Nature. v. 384: 6368-6372, 2000. 
LAEMMLI, U.K. Cleavage of structural proteins during the assembly of the head of bacteriophage T4. Nature. V. 227: 680-685, 1970.

LAUBER, K.; BLUMENTHAL, S. G.; WAIBEL, M.; WESSELBORG, S. Clearance of apoptotic cells: getting rid of the corpses (2004). In: G. M. COOPER.; R. E. HAUSMAN. The cell a molecular approach, 4 ed., ASM Press (Washington, D.C.), 689-718, 2007.

LEPSCH, M.; STRAYER, S. M. Omeprazole and placebo have same long-term effect on dyspepsia. J. Fam. Pract., v. 52:287-8, 2003.

LEPSCH, L. B.; MUNHOZ, A. D.; KAWAMOTO, E. M.; YSHII, L. M.; LIMA, L. S.; CURIBOAVENTURA, M. F.; SALGADO, T. M. L.; CURI, R.; PLANETA, C. S.; SCAVONE, C. Cocaine induced cell death and activates the transcription nuclear factor kappa-b in pc12 cells. Molecular Brain., v. 2:1-15, 2009.

LI, L. Y.; LUO, X.; WANG, X. Endonuclease G is an apoptotic DNase when released from mitochondria. Nature. v. 412: 95-99, 2003.

LI, G., XIAO, Y.; ZHANG, L. Cocaine Induces Apoptosis in Fetal Rat Myocardial Cells through the p38 Mitogen-Activatec Protein Kinase and Mitochondrial/Cytochrome c Pathways. $\mathbf{J}$ of Pharmacology and Experimental Therapeutics. V. 312:112-119, 2005.

LIU, Y.; PETERSON, D. A.; KIMURA, H.; SCHUBERT, D. Mechanism of cellular 3-(4,5dimethylthiazol-2-yl)-2,5-diphenyltetrazolium bromide (MTT) reduction. J. Neurochem., v. 69:581-593, 1997. 
MAGGI, L.; SHER, E.; CHERUBINI, E. Regulation of GABA release by nicotinic acetylcholine receptors in the neonatal rat hippocampus. J. Physiology., v. 536 (1):89-100, 2001.

MARKESBERY, W. R. The role of oxidative stress in Alzheimer Disease. Arch Neurol, 56:1449-1452, 1999.

MCCONKEY, D. J. Biochemical determinants of apoptosis and necrosis. Toxicology Letters. v. 99:157-168, 1998.

MESQUITA, L. S. M. Ações da metilecgonidina sobre a síntese de melatonina na glândula pineal de ratos. Dissertação para obtenção do grau de Mestre, Instituto de Ciências Biomédicas da Universidade de São Paulo,, 2009.

MOHAMAD, N.; GUYIÉRREZ, A.; NÚÑEZ, M.; COCCA, C.; MARTÍN, G.; CRICCO, G.; MEDINA, V.; RIVERA, E.; BERGOC, R. Mitochondrial apoptotic pathways. Biocell., v. 29:149161,2005

MOSMANN, T. Rapid colorimetric assay for cellular growth and survival: application to proliferation and cytotoxicity assays. J. Immunol. Methods., v. 65:55-63, 1983.

NAGATA, S. Apoptosis by death factor. Cell. v.88: 355-365, 1997.

NASSOGNE, M. C.; LOUAHED, J.; EVRARD, P.; COURTOY, P. Cocaine induces apoptosis in cortical neurons of fetal mice. Journal of Neurochemistry., v. 68:2442-2450, 1997. 
NEVES, S. R.; RAM, P. T.; IYENGAR, R. G protein patways (2002). In: G. M. COOPER.; R. E. HAUSMAN. The cell a molecular approach, 4 ed., ASM Press (Washington, D.C.), 599-648, 2007.

NETTO, F. A. C. S.; FERRAZ, E.M. Apoptose, neutrófilos e o cirurgião. Revista do Colégio Brasileiro de Cirurgiões. V.28:56-61, 2000.

NUÑEZ, G.; BENEDICT, M. A.; HU, Y.; INOHARA, N. Caspases: the proteases of the apoptotic pathway. Onogene., v. 17: 3237-3245, 1998.

O’BRIEN, C. P. Drogação e Uso Abusivo de Drogas. In: L. L. BRUNTON; J. S. LAZO; K. L. PARKER (Eds.). Goodman \& Gilman: As Bases Farmacológicas da Terapêutica, 11 ed., McGraw-Hill Interamericana do Brasil (RJ), 543-562, 2006.

OKI, T.; TAKAGI, Y.; INAGAKI, S.; TAKETO, M. M.; MANABE, T.; MATSUI, M.; YAMADA, S. Quantitative analysis of binding parameters of $[3 \mathrm{H}] \mathrm{N}$-methylscopolamine in receptor knockout mice. Brain Res. Mol. Brain Res., v. 133:6-11, 2005.

OTMAKHOVA, N. A., LISMAN, J. E. D1/D5 dopamine receptor activation increases the magnitude of early long-term potentiation at CA1 hippocampal synapses. J. Neurosci. v.16, 7478-7486, 1996.

PATEL, T. Apoptosis in hepatic pathophysiology.Clin Liver Dis. v. 4: 295-317, 2000.

PAUL, B. D.; WHORTER, L. K.; SMITH, M. L. Electron ionization mass fragmentometric detection of urinary ecgonidine a hydrolytic product of methylecgonidine as an indicator of smoking cocaine. J. Mass. Spectrom., v. 34:651-660, 1999.

PINKOSKI, M. J.; GREEN, D. R. Fas ligand, death gene.Cell Death Differ. v. 6: 174-181, 1999. 
POON, H. F., ABDULLAH, L., MULLAN, M. A., MULLAN, M. J., CRAWFORD, F. C. Cocaineinduced oxidative stress precedes cell death in human neuronal progenitor cells. Neurochem. Int. v. 50, 69-73, 2007.

RAFFA, R. B. The $M_{5}$ muscarinic receptor as possible target for treatment of drug abuse. Journal of Clinical Pharmacy and Therapeutics.,v. 34: 623- 629, 2009.

REED, J. C. Bcl2 family proteins. Oncogene. v.17: 3225-3236, 1998.

REED, J. C. Mechanisms of apoptosis. American Journal of Pathology. v. 157: 1415-1430, 2000.

ROSSER, B. G.; GORES, G. J. Liver cell necrosis: cellular mechanisms and clinical implications. Gastroenterology. v. 108: 252-275, 1995.

SCAFFIDI, C.; SCHMITZ, I.; KRAMMER, P. H.; PETER, M. C. The role of c-FLIP in modulation of CD95-induced apoptosis. J. Biol Chem. v. 274: 1541-1548, 1999.

SCHEIDWEILER, K. B.; PLESSINGER, M. A.; SHOJAIE, J.; WOOD, R. W.; KWONG, T. C. Pharmacokinetics and pharmacodynamics of methylecgonidine, a crack cocaine pyrolyzate. JPET, v. 307:1179-1187, 2003.

SCHELL, M. J.; IRVINE, R. F. Calcium-triggered exit of F-actin and $\mathrm{IP}_{3}$ 3-kinase A from dendritic spines is rapid and reversible. European J. Neuroscience. V. 24:2491-2503, 2006.

SEO, D. W.; LOPES-MERAZ, M. L.; ALLEN, S.; WASTERIAIN, C.G.; NIQUET, J. Contribution of a mitochondrial pathway to excitotoxic neuronal necrosis. J. Neurosci Res. v. 87(9): 20872094, 2009. 
SHARAN, N.; CHONG, V. Z.; NAIR, V. D.; MISHRA, R. K.; HAYES, R. J.; GARDNER, E. L. Cocaine treatment increases expression of a $40 \mathrm{kDa}$ catecholamine-regulated protein in discrete brain regions. Synapse, v. 47:33-44, 2003.

SHARKEY, J.; RITZ, M. C.; SCHENDEN, J. A.; HANSON, R. C.; KUHAR, M. J. Cocaine inhibits muscarinic cholinergic receptors in heart and brain. The Journal of Pharmacology and Experimental Therapeutics., v. 246:1048-1052, 1988.

SHIH, Y-T., CHEN, P. S., WU, C-H., TSENG, Y-T., WU, Y-C., LO, Y-C. Arecoline, a major alkaloid of the areca nut, causes neurotoxicity through enhancement of oxidative stress and suppression of the antioxidant protective system. Free Radic. Biol. Med. v. 49, 1471-1479, 2010.

SILVA, A R.; ZUCOLOTO S. A família do p53: aspectos estruturais e funcionais do p37 e do p63. Jornal Brasileiro de Patologia e Medicina Laboratorial. v. 39: 179-184, 2002.

SLEE, E. A.; HARTE, M. T.; KLUCK, R. M.; WOLF, B. B.; CASIANO, C. A.; NEWMWER, D. D.; WANG, H. G.; REED, J. C.; NICHOLSON, D. W.; ALNEMRI, E. S.; GREE, D. R.; MARTIN, S. J. Ordering the cytochrome c-initiated caspase cascade: hierarchical activation of caspase 2-3-67-8 and 10 in a caspase-9-dependent manner. J. Cell Biol. v. 144: 281-291, 1999.

THOMPSON, A. M.; GOSNELL, B. A.; WAGNER, J. J. Enhancement of long-term potentiation in the rat hippocampus following cocaine exposure. Neuropharmacology, v. 42 (8):1039-42, 2002. 
THOMPSON, A. M.; SWANT, J.; GOSNELL, B. A.; WAGNER, J. J. Modulation of long-term potentiation in the rat hippocampus following cocaine self-administration. Neuroscience, v. 127 (1):177-85, 2004.

THORBUM, A. Death receptor-induced cell kelling. Cell Signaling. v.16: 139-144, 2004.

UNODC- United Nations Office on Drugs and Crime; World Drug Report, 2012- www.unodc.org/

VANHAESEBROECK, B.; LEEVERS, S. J.; PANAYOTOU, G.; WATERFIELD, M. D. Phosphoinositide 3-kinases a conserved family of signal transducers. Trends Biochem Sci, v.22 (7):267-72, 1997.

VAUX, D. L.; SILKE, J. IAPs, RINGs and uquibitylation (2005). In: G. M. COOPER.; R. E. HAUSMAN. The cell a molecular approach, 4 ed., ASM Press (Washington, D.C.), 689-718, 2007.

WANG, X., SCWARZ, T. L. The mechanism of Ca2+-dependent regulation of kinesin-mediated mitochondrial motility. Cell., v.136: 163-174, 2008.

XIAO. D.; ZHANG. L. Upregulation of $\mathrm{Bax}$ and $\mathrm{Bcl}-2$ following prenatal cocaine exposure induces apoptosis in fetal rat brain. International Journal of Medical Sciences. v. 5, 295-302, 2008.

WILLIAMS, M. J.; ADINOFF, B. The role of acetycholine in cocaine addiction. Neuropsychopharmacology., v. 33:1779-1797, 2008.

YANG, Y.; KE, Q.; CAI, J.; XIAO, Y. F.; MORGAN, J. P. Evidence for cocaine and methylecgonidine stimulation of M2 muscarinic receptors in cultured human embryonic lung cells. British Journal of Pharmacology., v. 132:451-460, 2001. 
YUAN, C., ACOSTA, D. Jr. Effect of cocaine on mitochondrial electron transport chain evaluated in primary cultures of neonatal rat myocardial cells and in isolated mitochondrial preparations. Drug Chem. Toxicol. v. 23, 339-348, 2000.

ZACHOR, D. A.; MOORE, J. F.; SMOOT, T. M.; PERCY, A. K. Inhibitory effects of cocaine on NGF-induced neuronal differentiation: incomplete reversibility after a critical time period. Brain Res., v. 729: 270-2, 2003.

ZARAGozA, A., díEZ-FERnÁNDEZ, C., ALVAREZ, A. M., ANDRÉS, D., CASCALES, M. Mitochondrial involvement in cocaine-treated rat hepatocytes: Effect of $\mathrm{N}$-acetylcysteine and deferoxamine. Br. J. Pharmacol. v. 132, 1063-1070, 2001.

ZHANG, C.; LOMENZO, S. A.; BALLAY II, C. J.; TRUDELL, M. L. An Improved Synthesis of (+)2-Tropinone. J. Org. Chem., v. 62, 7888-7889, 1997. 
ANEXO 1 

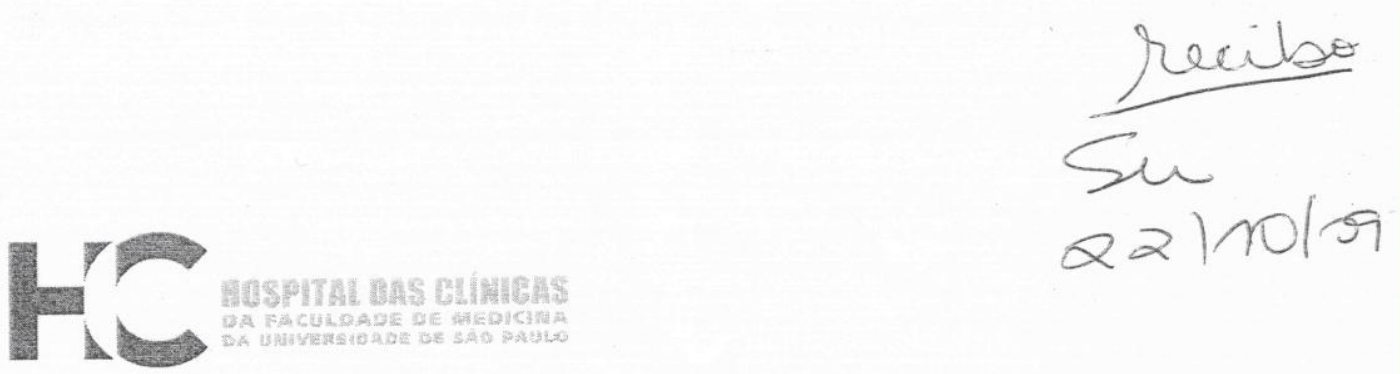

HOSPITAL BaS BLINERS

DA FACULDADE DE HAEDICARA

(1)

\section{APROVAÇÃO}

A Comissão de Ética para Análise de Projetos de Pesquisa CAPPesa da Diretoria Clínica do Hospital das Clínicas e da Faculdade de Medicina da Universidade de São Paulo, em sessão de 02/09/2009, APROVOU O Protocolo de Pesquisa $n^{\circ}$ 0841/09, intitulado: "CARACTERIZAÇĀO DAS VIAS DE MORTE CELULAR INDUZIDA PELA METILECGONIDINA, PRODUTO DA PIRÓLISE DA COCAÍNA" apresentado pela área de FISIOPATOLOGIA EXPERIMENTAL.

Cabe ao pesquisador elaborar e apresentar à CAPPesq, os relatórios parciais e final sobre a pesquisa (Resolução do Conselho Nacional de Saúde $n^{\circ} 196$, de 10/10/1996, inciso (X.2, letra "c").

Pesquisador (a) Responsável: Tania Marcourakis

Pesquisador (a) Executante: Lívia Mendonça Munhoz Dati

CAPPesq, 03 de Setembro de 2009

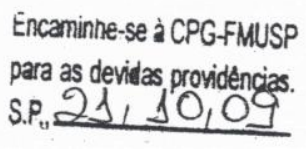

Prof. Dra. Elia Garcia Caldini
Programa Fisibpatologia Experimental
Pós-araduaçáo em Ciencias
Coordenador

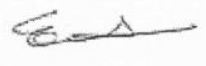

Prof. Dr. Eduardo Massad Presidente da Comissāo de Ética para Ánálise de Projetos de Pesquisa

Comissāo de Ética para Análise de Projetos de Pesquisa do HCFMUSP e da FMUSP Diretoria Clínica do Hospital das Clínicas da Faculdade de Medicina da Universidade de Săo Paulo Rua Ovídio Pires de Campos,

225, $5^{\circ}$ andar - CEP 05403010 - Săo Paulo - SP Fone: 01130696442 Fax: 01130696492 e-mail: cappesq@hcnet.usp.br / secretariacappesq2@hcnet.usp.br 
ANEXO 2 


\section{CERTIFICADO}

Certificamos que o Projeto intitulado "Caracterização das vias de morte celular induzida pela metilecgonidina, produto da pirólise da cocaína" protocolo $\mathrm{n}^{\circ} 633 / 09$, sob a responsabilidade de Dra. Maria Regina Lopes Sandoval e Dra. Tania Marcourakis, está de acordo com os Princípios Éticos na Experimentação Animal adotado pelo Colégio Brasileiro de Experimentação Animal (COBEA), e foi aprovado pela COMISSÃO DE ÉTICA NO USO DE ANIMAIS DO INSTITUTO BUTANTAN (CEUAIB) em reunião de 11/08/2009.

We certify that the research entitled "Caracterization of death pathway, induced by metilecgonidine, product by cocaine pirolise", protocol $n^{\circ} 633 / 09$, under the responsibility of Dra. Maria Regina Lopes Sandoval e Dra. Tania Marcourakis, is in agreement with the Ethical Principles in Animal Research, adopted by the Brazilian College of Animal Experimentation, and was approved by the ETHICAL COMMITTEE FOR ANIMAL RESEARCH of BUTANTAN INSTITUTE in the meeting of $\underline{08 / 11 / 2009}$

\begin{tabular}{|c|c|}
\hline Vigência do Projeto: & $\mathbf{N}^{\circ}$ de animais/espécie \\
$08 / 2009-08 / 2012$ & $\cdot$ \\
\hline Laboratório de farmacologia & $\begin{array}{c}250 / \text { Ratos wistar fêmeas/120/machos adultos e } \\
1200 \text { embriões }\end{array}$ \\
\cline { 2 - 2 }
\end{tabular}

De acordo:

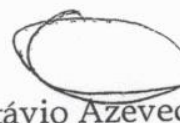

São Paulo, 13 de agosto de 2009.

Dr. Otávio Azevedo Mercadante

Diretor do Instituto Butantan 
ANEXO 3 


\title{
Neurotoxicity of Anhydroecgonine Methyl Ester, a Crack Cocaine Pyrolysis Product
}

\begin{abstract}
Raphael Caio Tamborelli Garcia,*,2 Livia Mendonça Munhoz Dati, ${ }^{*, 2}$ Suelen Fukuda, ${ }^{*}$ Larissa Helena Lobo Torres, ${ }^{*}$ Sidnei Moura, $\uparrow$ Nathalia Delazeri de Carvalho, $\$$ Daniel Carneiro Carrettiero,§ Rosana Camarini, II Adriana Cristina Levada-Pires,॥ Mauricio Yonamine,* Osvaldo Negrini-Neto,III Fernando Maurício Francis Abdalla,\$ Maria Regina Lopes Sandoval, $\$$ Solange Castro Afeche, $\$$ and Tania Marcourakis*,1

*Department of Clinical and Toxicological Analysis, School of Pharmaceutical Sciences, University of São Paulo, 05508-900, São Paulo/SP, Brazil; $\dagger$ Institute of Biotechnology, Technology Center, University of Caxias do Sul, 95070-560, Caxias do Sul/RS, Brazil; $\$$ Laboratory of Pharmacology, Butantan Institute, 05503-000, São Paulo/SP, Brazil; §Natural and Human Sciences Center, Federal University of ABC, 09090-400, Santo André/SP, Brazil; qIDepartment of Pharmacology, Institute of Biomedical Sciences, University of São Paulo, 05508-900, São Paulo/SP, Brazil; ||Department of Physiology, Institute of Biomedical Sciences, University of São Paulo, 05508-900, São Paulo/SP, Brazil; and |||Criminalistic Institute of São Paulo, 05507-060, São Paulo/SP, Brazil
\end{abstract}

${ }^{1}$ To whom correspondence should be addressed at Faculdade de Ciências Farmacêuticas da Universidade de São Paulo, Av Prof Lineu Prestes, 580 Bl 13B, 05508-900, São Paulo, SP, Brazil. Fax: +55-11-3091-2194. E-mail: tmarcour@usp.br.

${ }^{2}$ These authors contributed equally to this work.

Received February 13, 2012; accepted April 3, 2012

Smoking crack cocaine involves the inhalation of cocaine and its pyrolysis product, anhydroecgonine methyl ester (AEME). Although there is evidence that cocaine is neurotoxic, the neurotoxicity of AEME has never been evaluated. AEME seems to have cholinergic agonist properties in the cardiovascular system; however, there are no reports on its effects in the central nervous system. The aim of this study was to investigate the neurotoxicity of AEME and its possible cholinergic effects in rat primary hippocampal cell cultures that were exposed to different concentrations of AEME, cocaine, and a cocaine-AEME combination. We also evaluated the involvement of muscarinic cholinergic receptors in the neuronal death induced by these treatments using concomitant incubation of the cells with atropine. Neuronal injury was assessed using 3-(4,5-dimethylthiazol-2-yl)-2,5-diphenyltetrazolium bromide (MTT) and lactate dehydrogenase (LDH) assays. The results of the viability assays showed that AEME is a neurotoxic agent that has greater neurotoxic potential than cocaine after 24 and $48 \mathrm{~h}$ of exposure. We also showed that incubation for $48 \mathrm{~h}$ with a combination of both compounds in equipotent concentrations had an additive neurotoxic effect. Although both substances decreased cell viability in the MTT assay, only cocaine increased LDH release. Caspase-3 activity was increased after 3 and $6 \mathrm{~h}$ of incubation with $1 \mathrm{mM}$ cocaine and after $6 \mathrm{~h}$ of 0.1 and 1.0mM AEME exposure. Atropine prevented the AEME-induced neurotoxicity, which suggests that muscarinic cholinergic receptors are involved in AEME's effects. In addition, binding experiments confirmed that AEME has an affinity for muscarinic cholinergic receptors. Nevertheless, atropine was not able to prevent the neurotoxicity produced by cocaine and the cocaine-AEME combination, suggesting that these treatments activated other neuronal death pathways. Our results suggest a higher risk for neurotoxicity after smoking crack cocaine than after cocaine use alone.

Key Words: anhydroecgonine methyl ester; neurotoxicity; crack cocaine; rat primary hippocampal cell culture.
Crack cocaine, the smoked form of cocaine, is a highly addictive drug, and its use was first reported in the 1980s in Europe and the United States (Hamid, 1992). Since then, its use has been increasing worldwide, and cocaine addiction is considered a major public health problem in several countries (Darke et al., 2002; Fischer et al., 2006; Haasen et al., 2004; Marsden et al., 2009; Oliveira and Nappo, 2008; Pavarin, 2006).

Crack is cocaine in its freebase form, which has a lower melting point $\left(96^{\circ} \mathrm{C}-98^{\circ} \mathrm{C}\right)$ than cocaine hydrochloride $\left(198^{\circ} \mathrm{C}\right)$. Therefore, the heating of freebase cocaine produces rapid cocaine volatilization and absorption by the lungs, and the drug reaches the brain faster than by any other route. This process results in the formation of anhydroecgonine methyl ester (AEME), also called methylecgonidine, a cocaine pyrolysis product that also has rapid pulmonary absorption (Fandiño et al., 2002). According to Martin et al. (1989) and Nakahara and Ishigami (1991), 50-80\% of cocaine is converted to AEME at temperatures of $255^{\circ} \mathrm{C}-420^{\circ} \mathrm{C}$, and at $650^{\circ} \mathrm{C}$, this conversion is greater than $80 \%$. Nevertheless, it is very difficult to predict the amount of cocaine converted to AEME due to variations in the temperature used to volatilize it, the smoking devices used, and the purity of freebase cocaine (Paul et al., 2005).

Use of crack cocaine can lead to loss of control over decision making and produces harmful neurological, psychiatric, cardiovascular, and respiratory consequences. It has been associated with more violent behavior and aggression compared with the use of powdered cocaine (Cornish and O'Brien, 1996; Haasen et al., 2005). The neurological and psychiatric effects of crack use include the development of seizures, intracerebral hemorrhage, vascular spasm (Brown et al., 1992), and higher levels of anxiety, depression, and paranoid ideation (Gossop et al.,

(C) The Author 2012. Published by Oxford University Press on behalf of the Society of Toxicology. All rights reserved.

For permissions, please email: journals.permissions@oup.com 
2002). Although crack cocaine reaches the brain very quickly, its short-term effects make users to smoke at a high frequency, which leads to a rapid development of dependence.

Cocaine in its hydrochloride or base forms has been associated with brain atrophy (Sim et al., 2007), in addition to abnormalities of brain metabolic (Volkow et al., 2004) and electrical activities (Reid et al., 2006). Smith et al. (1993) demonstrated that high doses of cocaine could inhibit hippocampal long-term potentiation, a process involved in memory formation. The relationship between these brain alterations and an individual's neurocognitive function has also been investigated. In fact, neurocognitive dysfunctions, such as disruption of verbal memory and attention, have been reported in crack users (Cunha et al., 2004; De Oliveira et al., 2009; Di Sclafani et al., 2002).

Cocaine neurotoxicity has been demonstrated in several biological models, both in vivo and in vitro. For instance, excitotoxicity has been demonstrated in cocaine-exposed rats (Huber et al., 2001; Schilström et al., 2006), cocaine activates apoptosis in a dopaminergic cell line (PC12 cells) and in primary neuron cultures (Imam et al., 2005; Lepsch et al., 2009), and cocaine induces oxidative stress in human neuronal progenitor cells (Poon et al., 2007). Cocaine has also been shown to potentiate the neurotoxicity induced by Tat, a human immunodeficiency virus (HIV) protein with an important role in the pathogenesis of HIV dementia (Aksenov et al., 2006). Although some results indicate cocaine neurotoxicity, Goodman and Sloviter (1993) were unable to find any evidence of cocaine-induced neuronal damage in rats after acute and chronic treatments.

Understanding the possible neurotoxicity of AEME would raise a new hypothesis about the neurotoxic potential of crack cocaine. The few studies available on the effects of AEME have been conducted in the peripheral nervous system. Erzouki et al. (1995) showed that intravenous administration of AEME in rabbits reduced the blood pressure and heart rate and increased the respiratory rate. Moreover, AEME showed a negative inotropic effect in cultures derived from human ventricular trabeculae due to a decrease in calcium availability during muscular contraction. This effect is possibly mediated through muscarinic cholinergic receptors, a process that is reversed by atropine, a nonspecific muscarinic receptor antagonist (Woolf et al., 1997). Scheidweiler et al. (2003) showed that, in sheep, AEME produces cardiovascular effects that are also consistent with a muscarinic cholinergic effect. Significant hypotension and tachycardia occurred in all sheep, and these effects were antagonized by intravenous treatment with atropine.

According to Bradley et al. (2003), activation of the cholinergic $M_{1}$-muscarinic subtype of receptors (G1 protein-coupled receptors) may lead to an increase in intracellular calcium, which can activate the caspase pathways, resulting in neuronal death. In fact, Shih et al. (2010) demonstrated that arecoline, a muscarinic cholinergic receptor agonist used as a therapy in patients with Alzheimer's disease, induced neuronal apoptotic death through attenuation of the antioxidant system, which enhanced oxidative stress.
Our aim was to investigate the effects of AEME in rat primary hippocampal cell cultures because the hippocampus is one of the most important regions involved in learning and memory, and it is rich in muscarinic cholinergic receptors. Thus, we evaluated the following questions: (1) whether AEME has cholinergic agonist properties, (2) the neurotoxicity of AEME, (3) the contribution of the cocaine-AEME combination to neurotoxicity, and (4) whether this neurotoxicity is dependent on muscarinic cholinergic receptors.

Importantly, this is the first study to evaluate the neurotoxicity of AEME. Furthermore, this is also the first study to verify cocaine neurotoxicity in rat primary hippocampal cell cultures.

\section{MATERIALS AND METHODS}

Animals. Pregnant Wistar rats weighing 230-250 g were obtained from the Butantan Institute, São Paulo, Brazil. They were housed in plastic cages and maintained in a room with constant temperature $\left(22 \pm 1^{\circ} \mathrm{C}\right)$ on a 12:12-h light/dark cycle (lights on at 7:00 A.M.). Food and water were provided ad libitum. This study was performed according to National Institutes of Health guidelines and approved by the Animal Use Ethics Committee of the Butantan Institute and the Animal Experimentation Ethics Committee of the School of Pharmaceutical Sciences at the University of São Paulo.

Synthesis of AEME. AEME was synthesized using cocaine that was generously donated by the Criminal Institute of São Paulo to the Laboratory of Toxicological Analyses (School of Pharmaceutical Sciences, University of São Paulo) for research purposes. The cocaine was purified to $95 \%$ purity.

Briefly, a $5 \mathrm{mM}(1.70 \mathrm{~g})$ cocaine hydrochloride solution was refluxed in $50 \mathrm{ml}$ of concentrated hydrochloric acid for $24 \mathrm{~h}$. Then, the mixture was cooled to room temperature, diluted with $30 \mathrm{ml}$ of water and extracted with diethyl ether $(2 \times 255 \mathrm{ml})$ to remove benzoic acid. The aqueous phase was then evaporated under vacuum to dryness. The white solid was further dried under vacuum at $100^{\circ} \mathrm{C}$ for $24 \mathrm{~h}$ (Zhang et al., 1997). This produced crude anhydroecgonine hydrochloride $(0.96 \mathrm{~g}, 95 \%)$, which was used in the next step without further purification. The product was confirmed by its melting point of $239^{\circ} \mathrm{C}-244^{\circ} \mathrm{C}$. A solution prepared with $50 \mathrm{ml}$ of dry methanol and $3 \mathrm{mM}(0.61 \mathrm{~g})$ of the previously synthesized anhydroecgonine hydrochloride was stirred and bubbled with dry gaseous $\mathrm{HCl}$ for $4 \mathrm{~h}$. Thereafter, the mixture was refluxed for $6 \mathrm{~h}$, and the solvent was evaporated under vacuum. The yellow oil that remained was dried under vacuum for $24 \mathrm{~h}$. This produced crude AEME $(0.50 \mathrm{~g}, 99 \%)$ that was used without further purification. The product was evaluated by proton nuclear magnetic resonance $\left({ }^{1} \mathrm{H}-\mathrm{NMR}\right)$ and electrospray ionization-mass spectrometry (ESI-MS) in accordance with the literature. ${ }^{1} \mathrm{H}-\mathrm{NMR}\left(300.13 \mathrm{MHz}, \mathrm{CDCl}_{3}\right.$, tetramethylsilane: $\left.0 \mathrm{ppm}\right): 6.93$, $\mathrm{C}=\mathrm{C}-H(1 \mathrm{H}, \mathrm{s}) ; 3.79, \mathrm{OCH}_{3}(3 \mathrm{H}, \mathrm{s}) ; 2.75, \mathrm{NCH}_{3}(3 \mathrm{H}, \mathrm{s}) ; 2.78-1.93(8 \mathrm{H}, \mathrm{m})$; $\operatorname{ESI-MS}(\mathrm{m} / \mathrm{z}): 182[\mathrm{M}+\mathrm{H}]^{+} ; 151\left[\mathrm{M}-\mathrm{OCH}_{3}+\mathrm{H}\right]^{+} ; 122\left[\mathrm{M}-\mathrm{COOCH}_{3}\right]$ (Kline et al., 1990).

Rat primary hippocampal cell culture. Hippocampal neurons were dissociated from the hippocampi of E18-E19 Wistar rat embryos. Pregnant rats were anesthetized with pentobarbital $(45 \mathrm{mg} / \mathrm{kg})$, and the fetuses were rapidly euthanized by decapitation to remove their hippocampi. The tissues were placed into a Petri dish containing $100 \mathrm{U} / \mathrm{ml}$ penicillin and $100 \mu \mathrm{g} / \mathrm{ml}$ streptomycin (Gibco) in cooled neurobasal medium (Gibco). The hippocampi were washed with Hank's Balanced Salt Solution and subjected to mechanical fragmentation. The isolation of hippocampus cells was performed using proteolytic digestion with trypsin (Sigma; Jahr and Stevens, 1987; Silva et al., 2006). The hippocampus fragments were transferred to $0.25 \%$ trypsin in Earl's Balanced Salt Solution (EBSS) solution, pH 7.2-7.4, and were incubated for $10 \mathrm{~min}$ at $37^{\circ} \mathrm{C}$. Following trypsinization, the cells were washed with an 
EBSS solution containing 277.5 U/ml DNase (Sigma) and 10\% fetal bovine serum (Gibco). After dispersion with Pasteur pipettes of different diameters, the tissue was resuspended in neurobasal medium (Gibco) supplemented with $0.5 \mathrm{mM}$ L-glutamine, $25 \mu \mathrm{M}$ L-glutamic acid, $100 \mathrm{U} / \mathrm{ml}$ penicillin, $100 \mu \mathrm{g} / \mathrm{ml}$ streptomycin, and 2\% B27 supplement (Gibco) to reduce glial cell proliferation (Brewer et al., 1993; Silva et al., 2006). Then, the cells were seeded onto $0.01 \%$ poly-L-lysine-coated multiwell culture plates and maintained at $37^{\circ} \mathrm{C}$ in a humidified atmosphere of $5 \% \mathrm{CO}_{2}$, for 7-8 days, the time required for maturation of hippocampal neurons. On the second day, half of the old medium was replaced with the same volume of a fresh medium of the same composition. On the seventh day, the cells were incubated with cocaine and/or AEME at several concentrations for $3,6,12,24$, or $48 \mathrm{~h}$, depending on the experiment. For the assessment of cell viability, hippocampal neurons were plated on polyL-lysine-coated 96-well culture plates at a density of $2 \times 10^{5} \mathrm{cells} / \mathrm{cm}^{2}$.

Characterization of cultured cell types by immunohistochemistry. Immunofluorescent labeling was used to characterize the cell types present in the culture. Coverslips with attached cells were removed from the culture medium with forceps and washed once for $5 \mathrm{~min}$ in ice-cold phosphate-buffered saline (PBS). Then, the cells were fixed in a mixture of acetone and methanol (1:1) for $10 \mathrm{~min}$ at $-20^{\circ} \mathrm{C}$. Prior to staining, the cells were permeabilized in PBS containing $0.2 \%$ Triton for $30 \mathrm{~min}$ at room temperature. The coverslips were blocked to prevent nonspecific antibody binding by incubating them at room temperature for 30 minutes in PBS containing $2 \%$ normal goat serum, $4 \%$ bovine serum albumin, and $0.2 \%$ Triton on a rocker set at 12 cycles $/ \mathrm{min}$. The neurons were labeled with mouse anti-microtubule-associated-protein 2 (MAP2) primary antibody $\left(1: 2000\right.$, Sigma) overnight at $4^{\circ} \mathrm{C}$, and the astroglia with rabbit anti-glial-fibrillary-acidic protein (GFAP) primary antibody (1:1500, Sigma) for $1 \mathrm{~h}$ at room temperature. Afterward, the coverslips containing the cells were washed thrice for $5 \mathrm{~min}$ and incubated for an additional $1 \mathrm{~h}$ with secondary anti-mouse (fluorescein, 1:200, Jackson) and anti-rabbit antibodies (Texas Red, 1:200, Jackson). After washing thrice for $5 \mathrm{~min}$, the dishes were mounted with mounting media containing 4,6-diamidino-2-phenylindole (DAPI; Vector), which labels the nuclei of all the cells present in the culture (total cells). Finally, the cells were analyzed under a fluorescence microscope (Nikon eclipse TE300).

MTT-reduction assay. Cell viability was evaluated using the 3-(4,5-dimethylthiazol-2-yl)-2,5-diphenyltetrazolium bromide (MTT) reduction assay (Liu et al., 1997; Mosmann, 1983). Briefly, the yellow compound is reduced to formazan, a purple product, by the mitochondrial reductase enzymes of viable cells, and the absorbance of the cells was measured at $570 \mathrm{~nm}$. In all cell viability tests, $250 \mathrm{mM} \mathrm{KCl}$ was used as a positive control.

After each period of incubation with cocaine, AEME, or a cocaine-AEME combination, all the medium was removed, and $100 \mu \mathrm{l}$ of MTT solution $(5 \mathrm{mg}$ / $\mathrm{ml}$ MTT in PBS and neurobasal medium without phenol red [1:9, v/v]) were added. After $3 \mathrm{~h}$ of incubation with MTT at $37^{\circ} \mathrm{C}$ in a humidified atmosphere of $5 \% \mathrm{CO}_{2}, 100 \mu \mathrm{l}$ of dimethyl sulfoxide was added to each well. After $30 \mathrm{~min}$ of shaking, the absorbance at $570 \mathrm{~nm}$ was measured in a multiwell plate reader (BioTek Power Wave XS2); this absorbance has a direct correlation with cell viability (Abe and Saito, 1999; Ioudina et al., 2004). The same test was performed in the presence of 1,10 , and $50 \mu \mathrm{M}$ atropine to verify the involvement of muscarinic cholinergic receptors in neuronal death. The assay was performed in quintuplicate, and the results were expressed as a percentage of the control value.

Lactate dehydrogenase activity assay. The membrane integrity of the cells was evaluated by measuring the release of intracellular lactate dehydrogenase ( $\mathrm{LDH}$ ) into the medium. This enzyme converts pyruvate to lactate by consuming NADH, which is kinetically measured in the supernatant, and the amount of conversion is directly correlated to the LDH released (Silva et al., 2006). Therefore, cell viability is inversely proportional to the LDH released.

A $20-\mu 1$ aliquot of the supernatant medium and $170 \mu$ lof buffer solution (120mM Tris- $\mathrm{HCl}, 3.4 \mathrm{mM} \mathrm{NADH}, 50 \mu \mathrm{g} / \mathrm{ml}$ antimycin A in ethanol, $1 \%$
Triton-X 100, and Milli-Q water; 50:5:1:5:32) were added to each well of a 96 -well plate. To ensure that all the pyruvate present in the sample had been consumed, the absorbance at $340 \mathrm{~nm}$ was measured in a multiwell plate reader (SpectraMax Plus, Molecular Devices) at intervals of $20 \mathrm{~s}$ for 15-20 min or until complete stability of the readings. Then, $10 \mu \mathrm{l}$ of a $20-\mathrm{mM}$ pyruvate solution was added to each well, and the absorbance at $340 \mathrm{~nm}$ was measured at intervals of $20 \mathrm{~s}$ for at least $5 \mathrm{~min}$. The kinetic curve was traced at a linear location on the graph that contained measurements taken for at least 3 min (Jayalakshmi et al., 2005). This assay was performed in quintuplicate, and the results were expressed as pmol of NADH consumption/ minute/cell.

Caspase-3 activity. Caspase-3 activity was assayed as described by Melo et al. (2010), with minor modifications. The cells were centrifuged at $1000 \times \mathrm{g}$ for $15 \mathrm{~min}$ at $4^{\circ} \mathrm{C}$, and the pellet obtained was resuspended in $200 \mu \mathrm{l}$ of lysis buffer containing $10 \%$ sucrose, $0.1 \%$ 3-((3-cholamidopropyl)dimethylammonio)-1-propanesulfonic acid (CHAPS), $100 \mathrm{mM}$ 4-(2-hydroxyethyl)-1-piperazineethanesulfonic acid (HEPES; pH 7.4), $10 \mathrm{mg}$ / $\mathrm{ml}$ leupeptin, $10 \mathrm{mg} / \mathrm{ml}$ aprotinin, $200 \mathrm{mM}$ phenylmethylsulfonyl fluoride (PMSF), and $10 \mathrm{mM}$ dithiothreitol (DTT). The cells were incubated for 30 $\min$ at $4^{\circ} \mathrm{C}$ and centrifuged at $12,000 \times \mathrm{g}$ for $30 \mathrm{~min}$ at $4^{\circ} \mathrm{C}$. The supernatant was collected, and the protein content was determined by the Bradford (1976) method. Caspase protease activity was determined by incubating the lysate (20 $\mu \mathrm{g}$ of total protein) with $50 \mathrm{mM}$ of the fluorescent substrate acetyl Asp-GluVal-Asp 7-amido-4-methylcoumarin (AC-DEVD-AMC; for caspase-3) in a buffer containing 10\% sucrose, 100mM HEPES ( $\mathrm{pH} 7.4$ ), $10 \mathrm{mg} / \mathrm{ml}$ leupeptin, $10 \mathrm{mg} / \mathrm{ml}$ aprotinin, 200mM PMSF, and 10mM DTT. Caspase activity was assessed by measuring, at 5-min intervals, the fluorescence of 7-amino-4trifluoromethylcoumarin released over a period of $30 \mathrm{~min}$ using a spectrofluorometer (Molecular Devices SpectraMax Gemini XS, CA).

[3H]Quinuclidinyl benzilate binding assay. Hippocampal membranes, obtained from six animals for each experiment, were prepared as described by Cardoso et al. (2004). Hippocampi were isolated from rats, minced, and homogenized in $25 \mathrm{mM}$ Tris- $\mathrm{HCl}$, pH 7.4 (containing $0.3 \mathrm{M}$ sucrose, $5 \mathrm{mM}$ $\mathrm{MgCl}_{2}, 1 \mathrm{mM}$ EDTA, and 1mM PMSF), with an Ultra-Turrax homogenizer (T25, Ika Labortechnik, Staufen, Germany). The homogenate was centrifuged at $1000 \times \mathrm{g}$ for $10 \mathrm{~min}$. The supernatant was filtered through two layers of gauze and then centrifuged at $100,000 \times \mathrm{g}$ for $1 \mathrm{~h}$. The final $100,000 \times \mathrm{g}$ pellet was resuspended in $1 \mathrm{ml}$ of $25 \mathrm{mM}$ Tris- $\mathrm{HCl}$, $\mathrm{pH} 7.4$ (containing $5 \mathrm{mM} \mathrm{MgCl}_{2}$, $1 \mathrm{mM}$ EDTA, and $1 \mathrm{mM}$ PMSF), using a Dounce homogenizer and stored at $-80^{\circ} \mathrm{C}$. All procedures were carried out at $4^{\circ} \mathrm{C}$, and all solutions contained freshly added $1 \mathrm{mM}$ PMSF to inhibit proteolysis. The protein concentration of the membrane preparations was determined with a protein reagent assay (Bio-Rad Laboratories Inc., Hercules, CA). Competition-binding experiments were performed as described by Abdalla et al. (2004). Briefly, the hippocampus membrane preparation $(80 \mu \mathrm{g}$ protein $/ \mathrm{ml})$ was incubated for $1 \mathrm{~h}$ with $\left[{ }^{3} \mathrm{H}\right]$ quinuclidinyl benzilate (QNB; specific activity: $44 \mathrm{Ci} / \mathrm{mmol}$; New England Nuclear, Boston, MA) at a concentration near the distribution coefficients, $\mathrm{K}_{\mathrm{d}}$ values, reported by Cardoso et al. (2004) at $30^{\circ} \mathrm{C}$ in the absence and presence of increasing concentrations of AEME (or atropine, used as a control for the assay). The competition-binding data were analyzed using the weighted nonlinear least-squares interactive curve-fitting program of GraphPad Prism (GraphPad Prism Software Inc., San Diego, CA). A mathematical model for one or two binding sites was applied. The inhibition constant $\left(\mathrm{K}_{\mathrm{i}}\right)$ was determined from the competition-binding curves using the Cheng and Prusoff equation (Cheng and Prusoff, 1973). The potency was expressed by the negative logarithm of the $\mathrm{K}_{\mathrm{i}}$ value $\left(\mathrm{pK}_{\mathrm{i}}\right)$.

Statistical analysis. Assays were performed in quintuplicate and were repeated three (MTT) and two times (LDH). Caspase-3 assays were performed twice in quadruplicate. Data of the binding assays were representative of four independent experiments performed in duplicate.

The data were expressed as mean \pm SEM and were analyzed by ANOVA followed by Newman-Keuls post hoc test. A significance level of 95\% $(p<0.05)$ was accepted. 


\section{RESULTS}

\section{Characterization of the Cultured Cell Types by Immunohistochemistry}

The cultured cells were immunohistochemically characterized using MAP-2, a neuronal marker, and GFAP, an astrocytic marker. A predominance of neurons $(92 \%)$ was observed, with $8 \%$ of the cells being astrocytes (Fig. 1).

\section{Evaluation of AEME- and Cocaine-induced Neurotoxicity}

After incubating the cell cultures with cocaine or AEME for 24 or $48 \mathrm{~h}$ each, determination of neuronal viability using the MTT test showed a decrease in mitochondrial metabolism after $24 \mathrm{~h}$ of exposure to concentrations higher than $10^{-1} \mathrm{mM}$ AEME $[\mathrm{F}(10,154)=41.17, p<0.001]$ and $2 \mathrm{mM}$ cocaine $[\mathrm{F}(9,136)=$ $40.80, p<0.001]$; the percentage of viable cells was $64.6 \pm$ $8.2 \%$ and $67.3 \pm 7.1 \%$, respectively (Figs. 2A and 2C). After $48 \mathrm{~h}$ of exposure, a reduction in neuronal viability was observed for concentrations higher than $10^{-3} \mathrm{mM}$ AEME $[\mathrm{F}(10,154)=$ 112.0, $p<0.001]$ and $2 \mathrm{mM}$ cocaine $[\mathrm{F}(9,140)=117.6, p<$ $0.001]$; here, the percentage of viable cells was $64.3 \pm 3.9 \%$ and $61.4 \pm 6.9 \%$, respectively (Figs. $2 \mathrm{~B}$ and $2 \mathrm{D}$ ).

An elevation in the LDH content was observed after 24 and 48 $\mathrm{h}$ of exposure to $2 \mathrm{mM}$ cocaine $(21.8 \pm 0.5 \mathrm{pmol}$ of NADH consumption/minute/cell $[\mathrm{F}(9,90)=452.0, p<0.001] ; 32.1 \pm 1.6$ pmol of NADH consumption $/$ minute/cell $[\mathrm{F}(9,90)=241.9$, $p<0.001]$, respectively). There was no alteration in the LDH release after AEME treatments with any concentration or exposure time (Fig. 3).

\section{Neurotoxicity of a Cocaine-AEME Combination}

The concentrations used for these experiments were $1 \mathrm{mM}$ AEME and $2 \mathrm{mM}$ cocaine. These AEME and cocaine concentrations were chosen based on the MTT assay, which were able to reduce cell viability by $50 \%\left(\mathrm{LC}_{50}\right)$. Thus, these experiments were conducted with four groups: control, AEME, cocaine, and the cocaine-AEME combination.

Cocaine, AEME, or the cocaine-AEME combination did not promote neuronal death after 3 or $6 \mathrm{~h}$ of exposure. After $12 \mathrm{~h}$ of exposure, only the cocaine-AEME combination group showed neuronal death; $68.9 \pm 5.6 \%[\mathrm{~F}(4,66)=86.99, p<$ 0.001] of the cells survived (Fig. 4). After $24 \mathrm{~h}$ of exposure, neuronal death occurred in the cells incubated with cocaine, AEME, and the cocaine-AEME combination; the percentages of surviving cells were $77.0 \pm 2.4 \%[\mathrm{~F}(4,69)=231.4, p$ $<0.001], 76.8 \pm 3.9 \%[\mathrm{~F}(4,69)=231.4, p<0.001]$, and 73.3 $\pm 2.5 \% ;[\mathrm{F}(4,69)=231.4, p<0.001]$, respectively. After 48 $\mathrm{h}$ of exposure, the percentage of viable cells in the cultures treated with cocaine and AEME decreased to $58.6 \pm 5.3 \%$ $[\mathrm{F}(4,70)=192.1, p<0.001]$ and $61.5 \pm 3.6 \%[\mathrm{~F}(4,70)=$
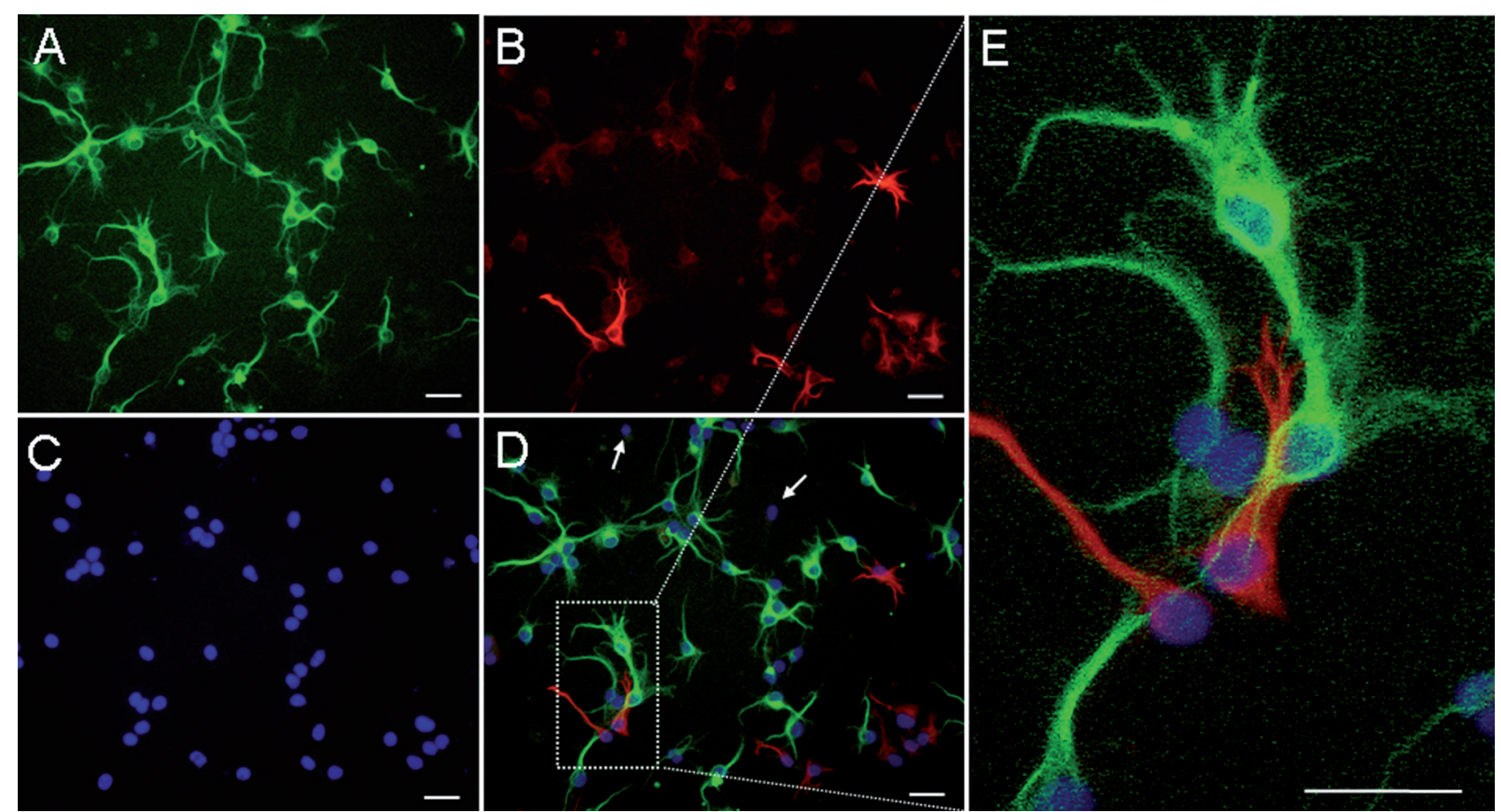

FIG. 1. Representative photomicrographs illustrating the percentages of neurons and astroglia in the primary neuronal cultures used to analyze the neurotoxicity of AEME and cocaine. (A) Cells immunopositive for microtubule-associated-protein 2 (MAP-2), which recognizes neurons (green; $n=5$ ). (B) Cells immunopositive for glial fibrillary acidic protein (GFAP), which recognizes astroglia (red). (C) Cells stained with 4,6-diamidino-2-phenylindole (DAPI), a nuclear marker (blue, total cells). (D) The merged image of A (neuronal cells), B (astroglia cells), and C (total cells). (E) The image corresponds to the regions shown in the white box in D. Few non-GFAP and non-MAP-2 cells (labeled only by the nuclear marker DAPI) were present in the cultures (white arrow in D). Scale bar: $30 \mu \mathrm{m}$. 
$192.1, p<0.001$ ], which corresponds to 41.4 and $38.5 \%$ neuronal death, respectively. The cocaine-AEME combination produced $78.5 \%$ cellular death $[\mathrm{F}(4,70)=192.1, p<0.001]$, suggesting an additive effect between cocaine and AEME because the sum of the individual responses $(79.9 \%$ neuronal death) is very similar to the combination response $(78.5 \%)$.

$\mathrm{LDH}$ was assayed only after 24 and $48 \mathrm{~h}$ of exposure to both drugs because neuronal death was not observed before $24 \mathrm{~h}$ of incubation with $1 \mathrm{mM}$ AEME or $2 \mathrm{mM}$ cocaine (Fig. 5). The cocaine-AEME combination increased LDH activity after $24(19.3 \pm 2.1 \mathrm{pmol}$ of $\mathrm{NADH}$ consumption/minute/cell) $[\mathrm{F}(4,45)=266.0, p<0.001]$ and $48 \mathrm{~h}$ of exposure $(29.4 \pm 0.6$ pmol of NADH consumption/minute/cell) $[\mathrm{F}(4,45)=64.1, p$ $<0.001]$.

A

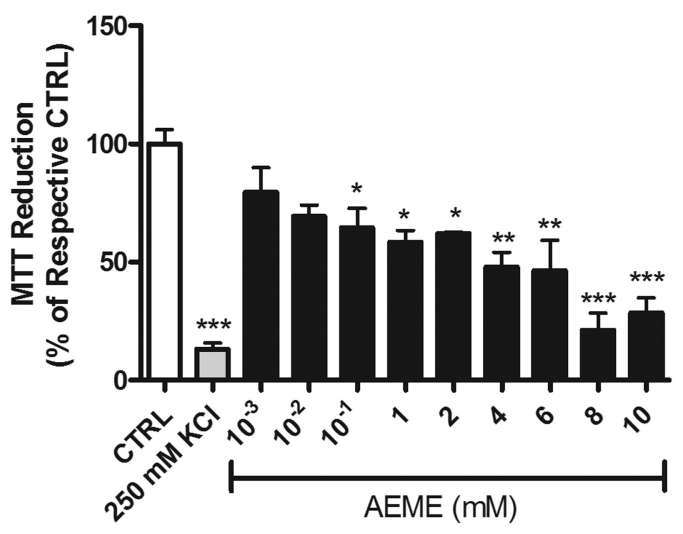

C

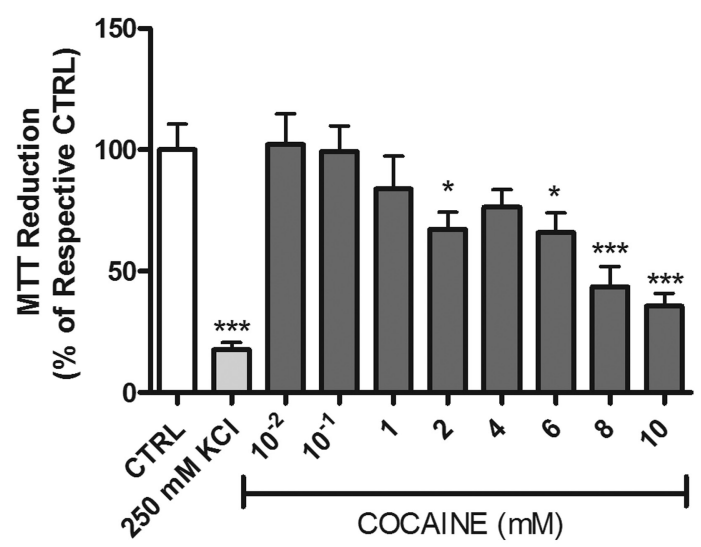

Caspase- 3 activity was evaluated after 3 and $6 \mathrm{~h}$ of exposure to cocaine and AEME at different concentrations, as well as after exposure to the cocaine-AEME combination. We observed that 0.1 and $1 \mathrm{mM}$ AEME increased caspase- 3 activity after $6 \mathrm{~h}$ of exposure $[\mathrm{F}(2,20)=5.09, p<0.05]$. Additionally, $1 \mathrm{mM}$ cocaine increased caspase- 3 activity after $3[\mathrm{~F}(2,20)=9.13, p<0.01]$ and $6 \mathrm{~h}[\mathrm{~F}(2,21)=9.28, p<0.01]$ of exposure (Fig. 6). However, there was no difference between the effects of 1 and $2 \mathrm{mM}$ cocaine on caspase- 3 activity after $6 \mathrm{~h}$ of exposure. In contrast, after $3 \mathrm{~h}$ of exposure, there was a decrease in caspase- 3 activity in the $2-\mathrm{mM}$ cocaine group compared with the $1-\mathrm{mM}$ cocaine group. There was no change in caspase- 3 activity in cells incubated with the cocaine-AEME combination for $3 \mathrm{~h}$. After $6 \mathrm{~h}$ of exposure, the cocaine-AEME combination group showed a decrease in this enzyme's activity $[\mathrm{F}(3,28)=6.76, p<0.01]$.

B

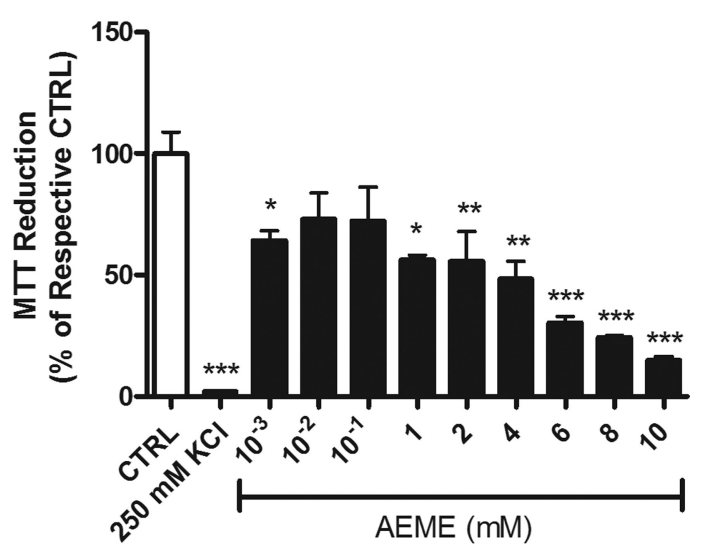

D

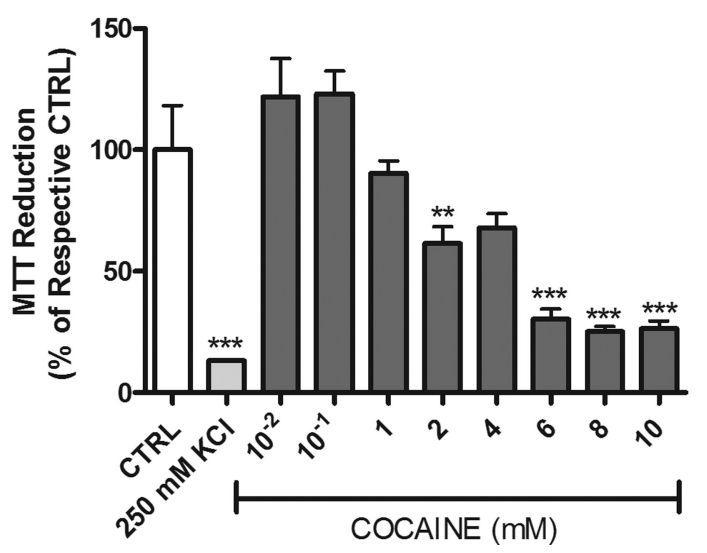

FIG. 2. The MTT cell viability results, expressed as the percentage of cells that chemically reduced MTT to formazan compared with control $(\mathrm{CTRL} ; n=$ five wells per group in each of the three independent assays). Here, $250 \mathrm{mM} \mathrm{KCl}$ was used as the positive control. (A) $24 \mathrm{~h}$ of AEME exposure, (B) $48 \mathrm{~h}$ of AEME exposure, (C) $24 \mathrm{~h}$ of cocaine exposure, and (D) $48 \mathrm{~h}$ of cocaine exposure. CTRL, control and AEME, anhydroecgonine methyl ester. * $p<0.05$, $* * p<0.01$, and $* * * p<0.001$, compared with CTRL (ANOVA and Newman-Keuls multiple comparison). 


\section{Involvement of the Muscarinic Cholinergic System in AEME Neurotoxicity}

To evaluate whether AEME binds to the muscarinic cholinergic system, a competition-binding assay was performed.

Effect of AEME on $\left[{ }^{3} H\right] Q N B$ Binding in Rat Hippocampus. The displacement curves for $\left[{ }^{3} \mathrm{H}\right] \mathrm{QNB}$ bound to the hippocampal membranes are shown in Figure 7 The profiles of displacement of the $\left[{ }^{3} \mathrm{H}\right] \mathrm{QNB}$ binding by AEME and atropine (positive control) in the hippocampus samples from male rats are shown in the figure. The analysis indicated a statistical preference for a one-site, rather than a two-site, fit, with a $\mathrm{pK}_{\mathrm{i}}$ of $4.15 \pm 0.15$, $n=4$, for AEME; and a $\mathrm{pK}_{\mathrm{i}}$ of $8.51 \pm 0.11, n=4$, for atropine.

MTT Assay After Incubation With Atropine. Figure 8 shows the neuronal viability test after incubating the cell cultures for

A

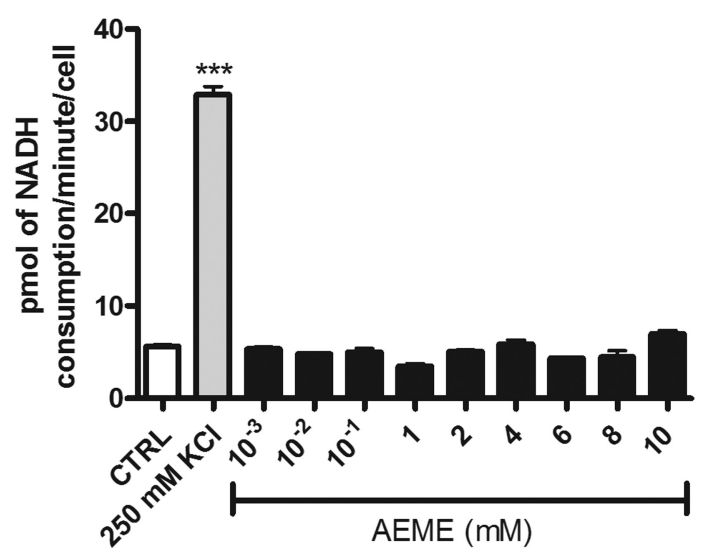

C

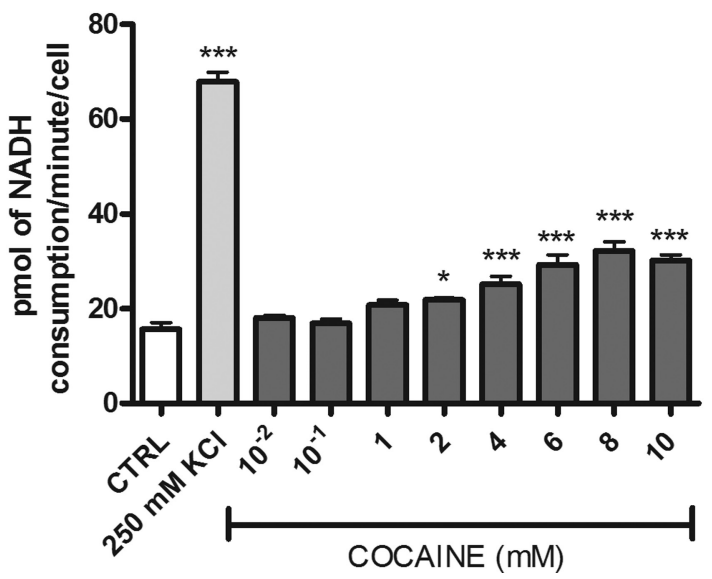

$24 \mathrm{~h}$ with cocaine, AEME, or cocaine-AEME combination in the absence and presence of atropine at different concentrations $(1[\mathrm{~F}(8,126)=14.53, p<0.001], 10[\mathrm{~F}(8,125)=20.21, p<0.001]$, or $50 \mu \mathrm{M}[\mathrm{F}(8,126)=29.89, p<0.001])$. Although all concentrations of atropine were able to prevent AEME neurotoxicity, these concentrations showed no effect in the groups exposed to cocaine and the cocaine-AEME combination.

\section{DISCUSSION}

The most interesting finding of this study is that AEME is even more toxic than cocaine in rat primary hippocampal cell cultures. Moreover, the cocaine-AEME combination had an additive neurotoxic effect, as observed using the MTT assay. We also suggest that neuronal death caused by AEME may be

\section{B}
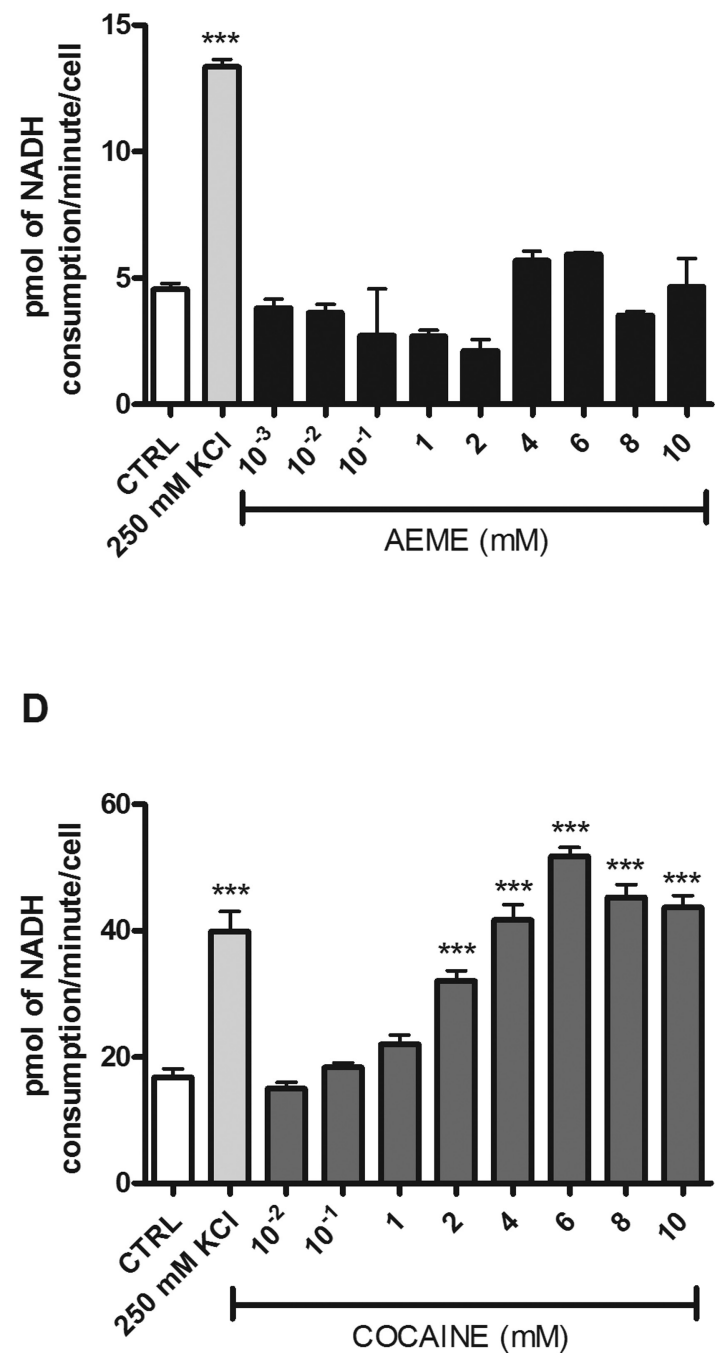

FIG. 3. The cytotoxicity assay results evaluated by LDH release into the culture medium ( $n=$ five wells per group in each of the two independent assays). Here, $250 \mathrm{mM} \mathrm{KCl}$ was used as the positive control. (A) $24 \mathrm{~h}$ of AEME exposure, (B) $48 \mathrm{~h}$ of AEME exposure, (C) $24 \mathrm{~h}$ of cocaine exposure, and (D) $48 \mathrm{~h}$ of cocaine exposure. CTRL, control and AEME, anhydroecgonine methyl ester. ${ }^{*} p<0.05$ and ${ }^{* * *} p<0.001$, compared with CTRL (ANOVA and Newman-Keuls multiple comparison). 


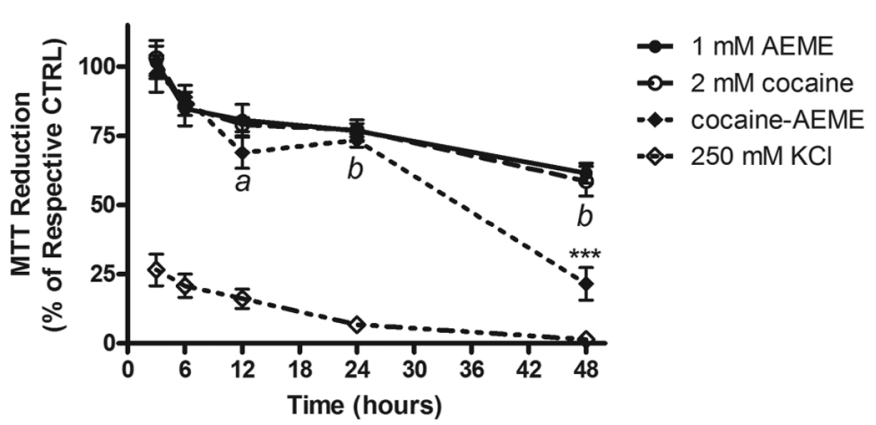

FIG. 4. The MTT curve after 3, 6, 12, 24, and $48 \mathrm{~h}$ of exposure to AEME and cocaine in equipotent concentrations and the cocaine-AEME combination ( $n=$ five wells per group in each of the three independent assays). Here, $250 \mathrm{mM} \mathrm{KCl}$ was used as the positive control. CTRL, control; AEME, anhydroecgonine methyl ester; cocaine-AEME, combination of $2 \mathrm{mM}$ cocaine and $1 \mathrm{mM}$ AEME. ${ }^{\mathrm{a}} p<0.001$ for the cocaine-AEME combination when compared with CTRL, ${ }^{\mathrm{b}} p<0.001$ for all groups when compared with CTRL, and $* * * p<$ 0.001 for the cocaine-AEME combination when compared with both cocaine and AEME (ANOVA and Newman-Keuls multiple comparison).

mediated by muscarinic receptors because we demonstrated both muscarinic-receptor binding by AEME and atropine protection of the hippocampal cells from AEME-induced neuronal death.

LDH release occurred only after exposure to cocaine and a cocaine-AEME combination. The increase in LDH release after these treatments is probably due to a more intense loss in membrane integrity caused by cocaine. Although LDH release is not enough to identify a necrotic process, we suggest that the induction of cell death by AEME involves apoptosis triggered by caspase- 3 activation, whereas cocaine toxicity is probably characterized by membrane injury at the concentration used.

The neurotoxicity of drugs of abuse is usually associated with oxidative stress and mitochondrial dysfunction, leading to cell death by apoptosis and/or necrosis (Cunha-Oliveira et al., 2008). This is the first work to evaluate the neurotoxicity of

A

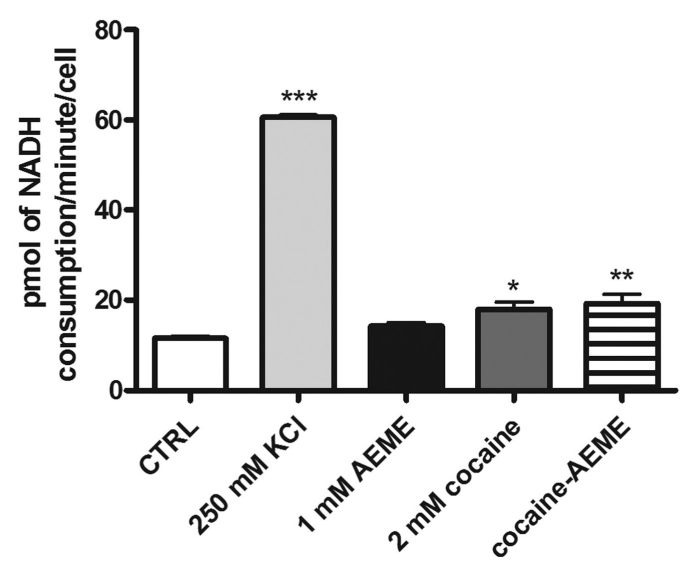

AEME and the first study to address cocaine neurotoxicity in hippocampal cells. Our results corroborate those presented by Poon et al. (2007), which showed increases in LDH activity in human neuronal progenitor cells after cocaine incubation, suggesting that necrosis is one of the mechanisms underlying cocaine-induced neuronal death. Cocaine's neurotoxic effects include massive dopamine release, which can be oxidized either spontaneously or by enzymatic processes. Consequently, oxidative species, such as superoxide anions, hydrogen peroxide, and quinones, are generated, leading to cellular damage of lipids, proteins, and DNA (Bisaglia et al., 2010). In fact, the involvement of mitochondrial damage and the participation of reactive oxygen species (ROS) in dopamine-mediated cocaine cytotoxicity has already been described (Kovacic, 2005). Other studies have reported cocaine induction of mitochondrial dysfunction and activation of the mitochondria-dependent intrinsic caspase cascade in cortical neurons (Cunha-Oliveira et al., 2006, 2010). Furthermore, inhibition of complex I of the mitochondrial respiratory chain in myocardial cells (Yuan and Acosta, 2000) and downregulation of mitochondrial gene expression in the rat cingulate cortex (Dietrich et al., 2004) have also been reported. The activation of caspase-3, described in this study, is in agreement with the results presented by Cunha-Oliveira $e t$ al. (2006, 2010). Moreover, AEME also seems to be an inducer of apoptosis, as caspase-3 activity was increased in the study. However, after exposure to the cocaine-AEME combination, the decrease in caspase- 3 activity suggests a change in the neuronal death mechanism. Caspase- 3 inhibition has been reported to induce cellular death by activation of necrotic pathways (Seo et al., 2009).

To investigate the combined neurotoxicity of cocaine and AEME, we performed the MTT and LDH assays with equipotent concentrations of cocaine and AEME after different periods of exposure. The neurotoxicity observed using the MTT assay was time-dependent. Although cocaine, AEME,

B

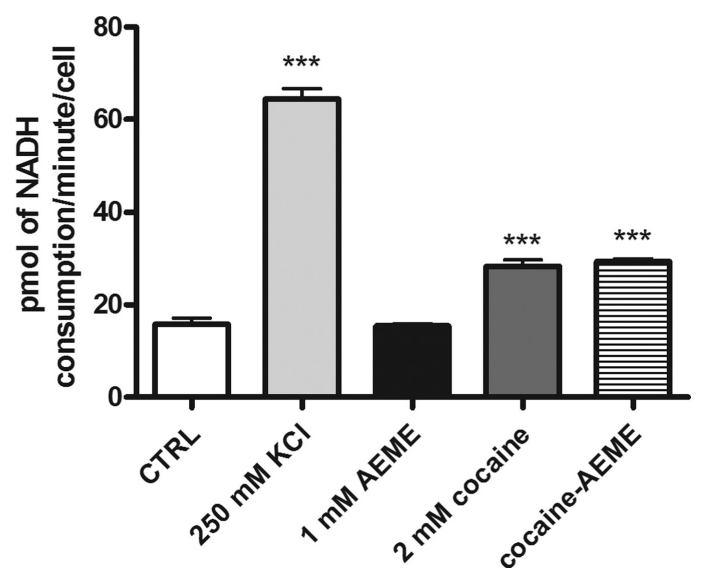

FIG. 5. The LDH assay ( $n=$ five wells per group in each of the two independent assays) after (A) $24 \mathrm{~h}$ of exposure and (B) $48 \mathrm{~h}$ of exposure. Here, $250 \mathrm{mM}$ $\mathrm{KCl}$ was used as the positive control. CTRL, control; AEME, anhydroecgonine methyl ester; cocaine-AEME, combination of $2 \mathrm{mM}$ cocaine and $1 \mathrm{mM}$ AEME. $* p<0.05,{ }^{* *} p<0.01$, and ${ }^{* * *} p<0.001$ compared with CTRL (ANOVA and Newman-Keuls multiple comparison). 
A

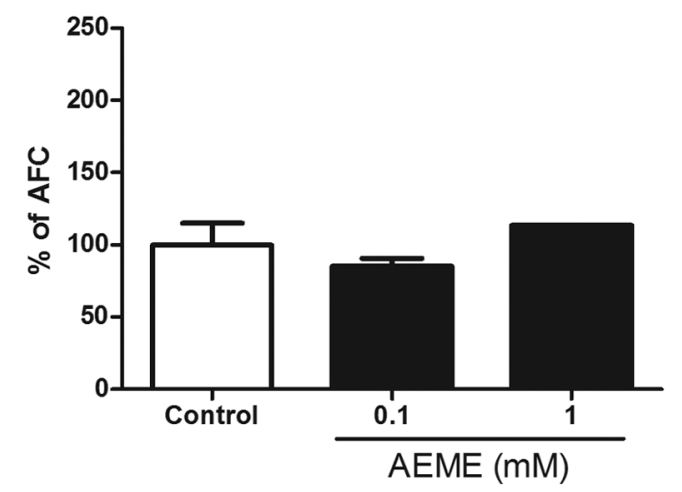

C

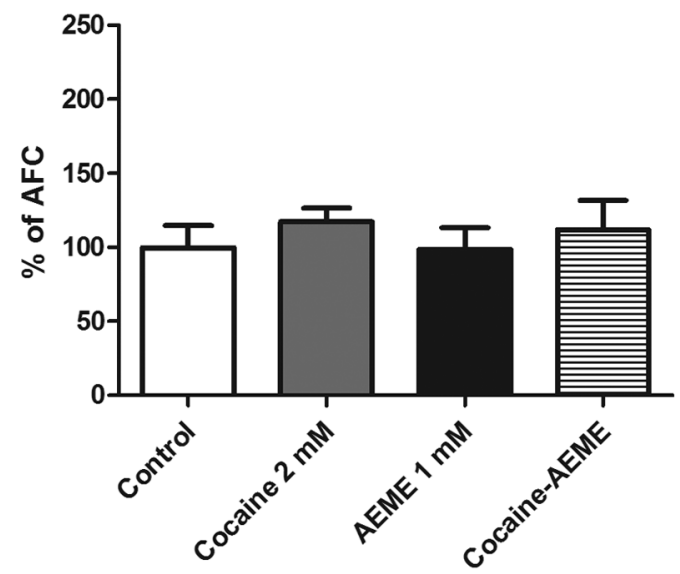

E

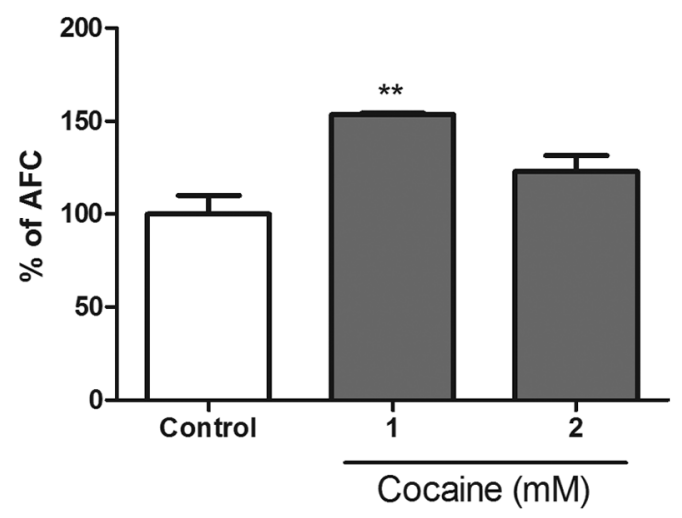

B

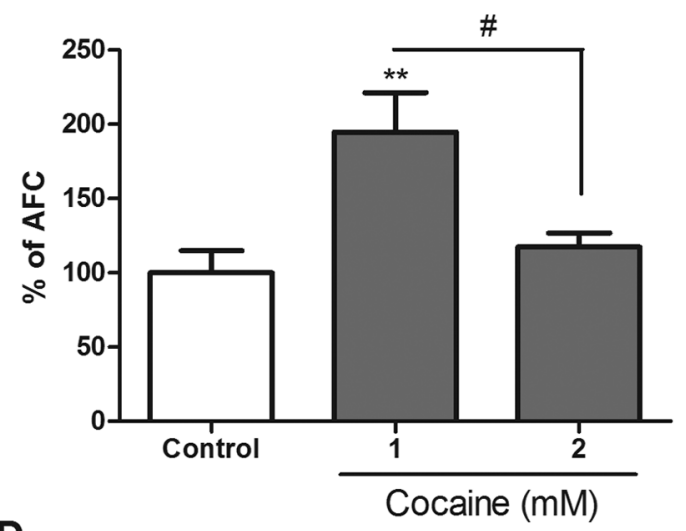

D

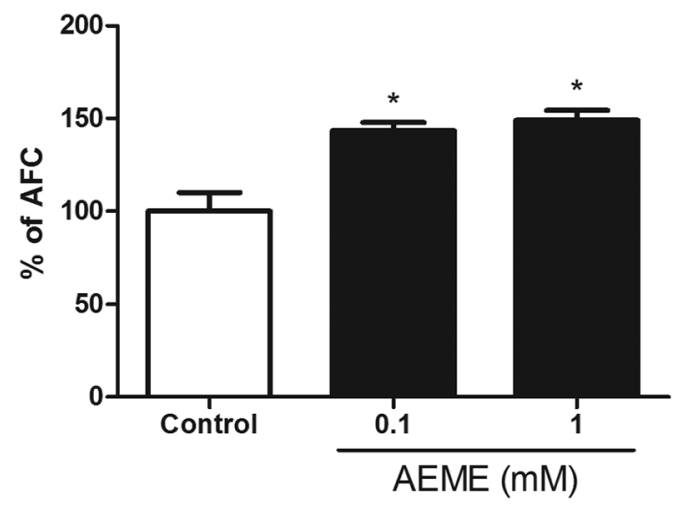

F

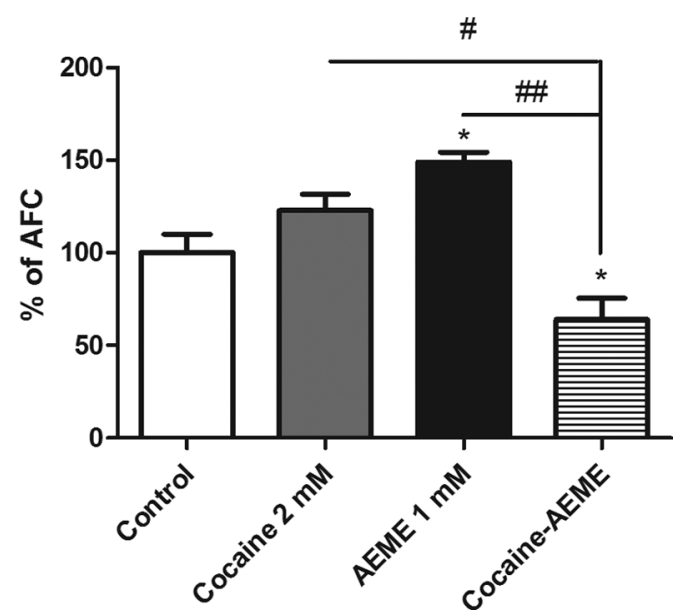

FIG. 6. Caspase-3 activity, measured as the percentage of 7-amino-4-trifluoromethylcoumarin (AFC; $n=$ four wells per group in each of the two independent assays), after 3 (A, B, and C) and $6 \mathrm{~h}$ of exposure (D, E, and F). AEME, anhydroecgonine methyl ester and cocaine-AEME, combination of $2 \mathrm{mM}$ cocaine and $1 \mathrm{mM}$ AEME. $* p<0.05$ and $* * p<0.01$ compared with CTRL; $\# p<0.05$ and \#\#p $<0.01$ intergroup comparison (ANOVA and Newman-Keuls multiple comparisons).

and the cocaine-AEME combination treatments decreased neuronal viability after 12 to $48 \mathrm{~h}$ of exposure, an additive effect occurred only at $48 \mathrm{~h}$. It is important to mention that the concentrations of $1 \mathrm{mM}$ AEME and $2 \mathrm{mM}$ cocaine used in these assays were the previously determined $\mathrm{LC}_{50}$ values. The cocaine concentration was in the range used by other groups $(50-2500 \mu \mathrm{M})$ in different cell types, such as embryonic brain cells, myocardial cells, hepatocytes, and PC12 cells (CunhaOliveira et al., 2010; Imam et al., 2005; Yuan and Acosta, 2000; Zaragoza et al., 2001). 


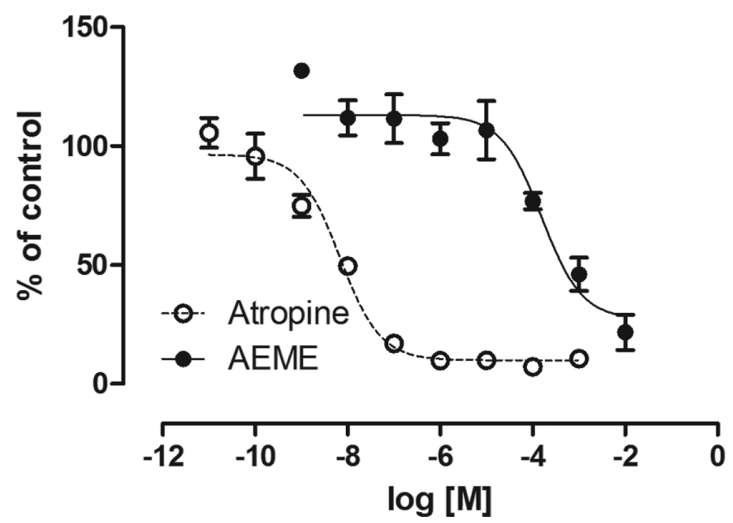

FIG. 7. The displacement curves induced by AEME and the muscarinic acetylcholine receptor (mAChR) antagonist atropine for $\left[{ }^{3} \mathrm{H}\right] \mathrm{QNB}$ bound to the hippocampal membranes from male rats. The data are plotted as percentages of binding in the absence of AEME or atropine. Each point and vertical line represent the mean \pm SEM of four different experiments performed in duplicate. AEME, anhydroecgonine methyl ester.

A

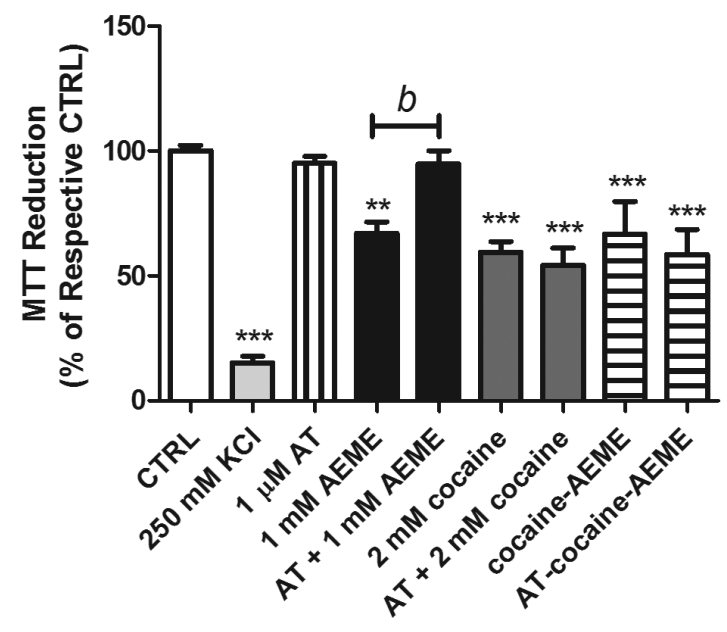

C

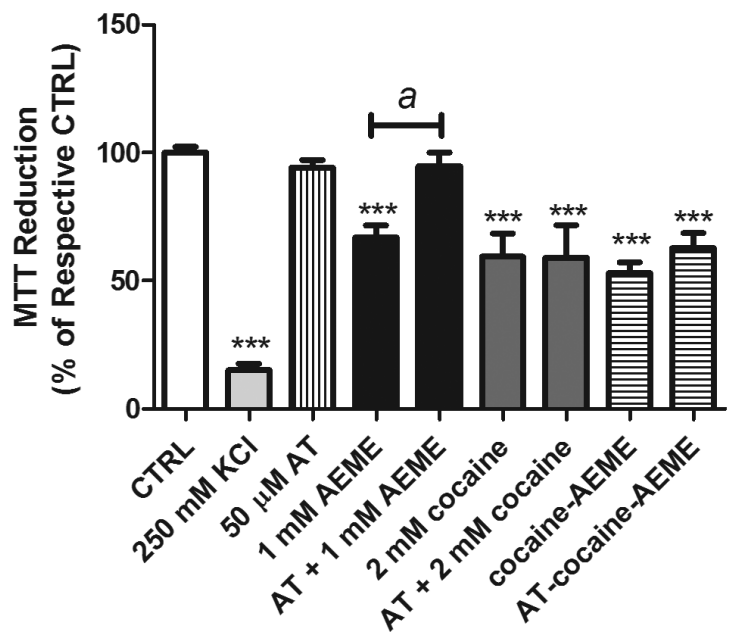

B

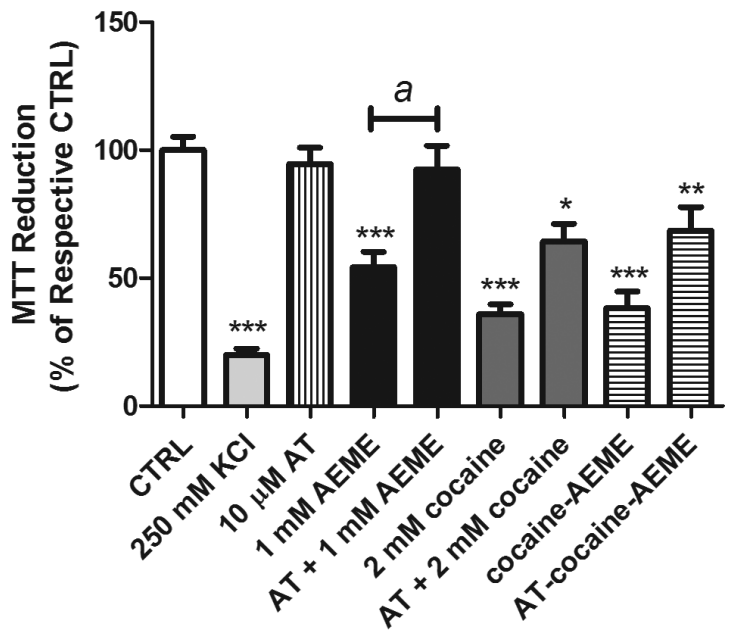

FIG. 8. The MTT cell viability results, expressed as the percentage of cells that chemically reduced MTT to formazan, compared with CTRL after $24 \mathrm{~h}$ of exposure ( $n=$ five wells per group in each of the three independent assays). In this test, $250 \mathrm{mM} \mathrm{KCl}$ was used as the positive control. Neuronal cells were incubated in the absence and presence of $1 \mu \mathrm{M}(\mathrm{A}), 10 \mu \mathrm{M}(\mathrm{B})$, and $50 \mu \mathrm{M}$ atropine (C). CTRL, control; AEME, anhydroecgonine methyl ester; AT, atropine; cocaine-AEME, combination of $2 \mathrm{mM}$ cocaine and $1 \mathrm{mM}$ AEME. ${ }^{*} p<0.05,{ }^{* *} p<0.01$, and ${ }^{* * *} p<0.001$, compared with CTRL. ${ }^{\mathrm{a}} p<0.001$ and ${ }^{\mathrm{b}} p<0.01$, compared with 1mM AEME (ANOVA and Newman-Keuls multiple comparison). 
The main neurotransmitters in hippocampus are the cholinergic and glutamatergic systems (Lendvai and Vizi, 2008). The hippocampus receives dopaminergic input from both the substantia nigra and the ventral tegmental area that projects into the hilus area and the CA1-subiculum region that expresses some dopaminergic receptors, such as D1, D2, and D5 subtypes, as well as the enzymatic machinery associated with this neurotransmitter (Otmakhova and Lisman, 1996). While dopamine is present in lower concentrations than acetylcholine in the hippocampus, cocaine-induced neurotoxicity in hippocampal cells may be due to toxic dopamine metabolites, which lead to oxidative stress (Dietrich et al., 2005; Poon et al., 2007).

Because AEME seems to have a peripheral muscarinic agonist effect (Erzouki et al., 1995; Scheidweiler et al., 2003; Woolf et al., 1997), we hypothesized that AEME's effects could be mediated by muscarinic receptors. In fact, atropine, an unspecific muscarinic antagonist, was able to prevent AEME-induced neurotoxicity, suggesting that muscarinic cholinergic activation is one of the mechanisms underlying neuronal death. Arecoline, a muscarinic cholinergic receptor agonist, produced neuronal apoptotic death at concentrations from 50 to $200 \mu \mathrm{M}$ (Shih et al., 2010). According to this study, arecoline depressed antioxidant defenses and increased ROS as well as caspase- 3 activity. Nevertheless, atropine was not able to prevent the neuronal death induced by cocaine and the cocaine-AEME combination. However, direct interactions of cocaine with the muscarinic system have also been described, with cocaine acting on both $\mathrm{M}_{1}$ and $\mathrm{M}_{2}$, as well as nicotinic receptors (Flynn et al., 1992; Niu et al., 1995). Our data did not confirm the interaction between cocaine and muscarinic receptors because our results did not show that atropine could reverse the effects of cocaine.

To characterize the effect of AEME on muscarinic acetylcholine receptors, different concentrations of AEME were examined for their ability to compete with $\left[{ }^{3} \mathrm{H}\right] \mathrm{QNB}$ for its binding sites in the rat hippocampus. The binding curve of the competition-binding experiments with AEME was suggestive of a single $\left[{ }^{3} \mathrm{H}\right] \mathrm{QNB}$ binding site, indicating that muscarinic receptors may be the target proteins of AEME. The $\mathrm{pK}_{\mathrm{i}}$ value obtained for AEME $(4.15 \pm 0.15)$ is very similar to the $\mathrm{pK}_{\mathrm{i}}$ values reported for arecoline, a classical muscarinic cholinergic agonist that has a similar chemical structure to AEME, in binding studies on cloned $\mathrm{M}_{1}-\mathrm{M}_{5}$ muscarinic receptors $(4.55 \pm 0.15$, $4.75 \pm 0.18,4.11 \pm 0.14,4.14 \pm 0.11$, and $4.83 \pm 0.12$, respectively; Dong et al., 1995). To validate the competition-binding assay, the nonselective muscarinic antagonist atropine was used as a positive control. The $\mathrm{pK}_{\mathrm{i}}$ value for atropine obtained in this study is also similar to those reported in the literature in binding studies on cloned $\mathrm{M}_{1}-\mathrm{M}_{5}$ muscarinic acetylcholine receptor (mAChRs; Dong et al., 1995).

In conclusion, we suggest that AEME is not just a biological marker of crack cocaine use. Its neurotoxicity, combined with that of cocaine, may predispose crack cocaine users to more serious deleterious outcomes compared with other cocaineadministration routes.

\section{FUNDING}

This work was supported by the Fundação de Amparo à Pesquisa do Estado de São Paulo (São Paulo Research Foundation FAPESP, grant numbers 2006/58631-2, 2009/11149-0, 2011/02734-6) and Conselho Nacional de Desenvolvimento Científico e Tecnológico (CNPq, grant numbers 471430/20072 ; 47122/2010-3).

\section{ACKNOWLEDGMENTS}

The authors gratefully acknowledge the support of Cássia Maria Braga Nunes from the Butantan Institute; and Dr Jarlei Fiamoncini and Prof. Dr Rui Curi from the Institute of Biomedical Sciences.

\section{REFERENCES}

Abe, K., and Saito, H. (1999). Both oxidative stress-dependent and independent effects of amyloid $\beta$ protein are detected by (3-4,5-dimethylthiazol2-yl)-2,5-diphenyltetrazolium bromide (MTT) reduction assay. Brain Res. 830, 146-154.

Abdalla, F. M. F., Maróstica, E., Picarelli, Z. P., Abreu, L. C., Avellar, M. C. W., and Porto, C. S. (2004). Effect of estrogen on muscarinic acetylcholine receptor expression in rat myometrium. Mol. Cell. Endocrinol. 213, 139-148.

Aksenov, M. Y., Aksenova, M. V., Nath, A., Ray, P. D., Mactutus, C. F., and Booze, R. M. (2006). Cocaine-mediated enhancement of Tat toxicity in rat hippocampal cell cultures: The role of oxidative stress and D1 dopamine receptor. Neurotoxicology 27, 217-228.

Bisaglia, M., Soriano, M. E., Arduini, I., Mammi, S., and Bubacco, L. (2010). Molecular characterization of dopamine-derived quinones reactivity toward NADH and glutathione: Implications for mitochondrial dysfunctions in Parkinson disease. Biochim. Biophys. Acta 1802, 699-706.

Bradford, M. M. (1976). A rapid and sensitive method for the quantitation of microgram quantities of protein utilizing the principle of protein-dye binding. Anal. Biochem. 72, 248-254.

Bradley, K. N., Rowan, E. G., and Harvey, A. L. (2003). Effects of muscarinic toxins MT2 and MT7, from green mamba venom, on $\mathrm{m} 1, \mathrm{~m} 3$ and m5 muscarinic receptors expressed in Chinese hamster ovary cells. Toxicon 41, 207-215.

Brewer, G. J., Torricelli, J. R., Evege, E. K., and Price, P. J. (1993). Optimized survival of hippocampal neurons in B27-supplemented Neurobasal, a new serum-free medium combination. J. Neurosci. Res. 35, 567-576.

Brown, E., Prager, J., Lee, H. Y., and Ramsey, R. G. (1992). CNS complications of cocaine abuse: Prevalence, pathophysiology, and neuroradiology. Am. J. Roentgenol. 159, 137-147.

Cardoso, C. C., Pereira, R. T. S., Koyama, C. A., Porto, C. S., and Abdalla, F. M. F. (2004). Effects of estrogen on muscarinic acetylcholine receptors in the rat hippocampus. Neuroendocrinology 80, 379-386.

Cheng, Y. C., and Prusoff, W. H. (1973). Relationship between the inhibition constant $\left(\mathrm{K}_{\mathrm{i}}\right)$ and the concentration of inhibitor which causes 50 percent inhibition $\left(\mathrm{IC}_{50}\right)$ of an enzymatic reaction. Biochem. Pharmacol. 22, 3099-3108.

Cornish, J. W., and O'Brien, C. P. (1996). Crack cocaine abuse: An epidemic with many public health consequences. Annu. Rev. Pub. Health 17, 259-273.

Cunha, P. J., Nicastri, S., Gomes, L. P., Moino, R. M., and Peluso, M. A. (2004). Neuropsychological impairments in crack cocaine-dependent inpatients: Preliminary findings. Rev. Bras. Psiquiatr. 26, 103-106. 
Cunha-Oliveira, T., Rego, A. C., Cardoso, S. M., Borges, F., Swerdlow, R. H., Macedo, T., and Oliveira, C. R. (2006). Mitochondrial dysfunction and caspase activation in rat cortical neurons treated with cocaine or amphetamine. Brain Res. 1089, 44-54.

Cunha-Oliveira, T., Rego, A. C., and Oliveira, C. R. (2008). Cellular and molecular mechanisms involved in the neurotoxicity of opioid and psychostimulant drugs. Brain Res. Rev. 58, 192-208.

Cunha-Oliveira, T., Rego, A. C., Garrido, J., Borges, F., and Oliveira, C. R. (2010). Neurotoxicity of heroin-cocaine combinations in rat cortical neurons. Toxicology 276, 11-17.

Darke, S., Kaye, S., and Topp, L. (2002). Cocaine use in New South Wales, Australia 1996-2000: 5 year monitoring of trends in price, purity, availability and use from the illicit drug reporting system. Drug Alcohol Depend. 67, $81-88$.

De Oliveira, L.G., Barroso, L. P., Silveira, C. M., Sanchez, Z. V. D. M., Ponce, J. C., Vaz, L. J., and Nappo, S. A. (2009). Neuropsychological assessment of current and past crack cocaine users. Subst. Use Misuse 44, 1941-1957.

Di Sclafani, V., Tolou-Shams, M., Price, L. J., and Fein, G. (2002). Neuropsychological performance of individuals dependent on crack-cocaine, crackcocaine and alcohol at 6 week and 6 months of abstinence. Drug Alcohol Depend. 66, 161-171.

Dietrich, J. B., Poirier, R., Aunis, D., and Zwiller, J. (2004). Cocaine downregulates the expression of the mitochondrial genome in rat brain. Ann. NY Acad. Sci. 1025, 345-350.

Dietrich, J. B., Mangeol, A., Revel, M. O., Burgun, C., Aunis, D., and Zwiller, J. (2005). Acute or repeated cocaine administration generates reactive oxygen species and induces antioxidant enzyme activity in dopaminergic rat brain structures. Neuropharmacology 48, 965-974.

Dong, G. Z., Kameyama, K., Rinken, A., and Haga, T. (1995). Ligand binding properties of muscarinic acetylcholine receptor subtypes (m1-m5) expressed in baculovirus-infected insect cells. J. Pharmacol. Exp. Ther. 274, 378-384.

Erzouki, H. K., Allen, A. C., Newman, A. H., Goldberg, S. R., and Schindler, C. W. (1995). Effects of cocaine, cocaine metabolites and cocaine pyrolysis products on the hindbrain cardiac and respiratory centers of the rabbit. Life Sci. 57, 1861-1868.

Fandiño, A. S., Toennes, S. W., and Kauert, G. F. (2002). Studies on hydrolytic and oxidative metabolic pathways of anhydroecgonine methyl ester (methylecgonidine) using microssomal preparations from rat organs. Chem. Res. Toxicol. 15, 1543-1548.

Fischer, B., Rehm, J., Patra, J., Kalousek, K., Haydon, E., Tyndall, M. W., and El-Guebaly, N. (2006). Crack across Canada: Comparing crack users and crack non-users in a Canadian multi-city cohort of illicit opioid users. Addiction 101, 1760-1770.

Flynn, D. D., Vaishnav, A. A., and Mash, D. C. (1992). Interactions of cocaine with primary and secondary recognition sites on muscarinic receptors. Mol. Pharmacol. 41, 736-742.

Goodman, J. H., and Sloviter, R. S. (1993). Cocaine neurotoxicity and altered neuropeptide $\mathrm{Y}$ immunoreactivity in the rat hippocampus: A silver degeneration and immunocytochemical study. Brain Res. 616, 263-272.

Gossop, M., Marsden, J., Stewart, D., and Kidd, T. (2002). Changes in use of crack cocaine after drug misuse treatment: 4-5 Year follow-up results from the National Treatment Outcome Research Study (NTORS). Drug Alcohol Depend. 66, 21-28.

Haasen, C., Prinzleve, M., Zurhold, H., Rehm, J., Güttinger, F., Fischer, G., Jagsch, R., Olsson, B., Ekendahl, M., Verster, A., et al. (2004). Cocaine use in Europe - A multi-centre study. Eur. Addict. Res. 10, 139-146.

Haasen, C., Prinzleve, M., Gossop, M., Fischer, G., and Casas, M. (2005). Relationship between cocaine use and mental health problems in a sample of European cocaine powder or crack users. World Psychiatry 4, 173-176.

Hamid, A. (1992). The developmental cycle of a drug epidemic: The cocaine smoking epidemic of 1981-1991. J. Psychoactive Drugs 24, 337-348.
Huber, J. D., Darling, S. F., Park, K. K., and Soliman, K. F. A. (2001). The role of NMDA receptors in neonatal cocaine-induced neurotoxicity. Pharmacol. Biochem. Behav. 69, 451-459.

Imam, S. Z., Duhart, H. M., Skinner, J. T., and Ali, S. F. (2005). Cocaine induces a differential dose-dependent alteration in the expression profile of immediate early genes, transcription factors, and caspases in PC12 cells: A possible mechanism of neurotoxic damage in cocaine addiction. Ann. NY Acad. Sci. 1053, 482-490.

Ioudina, M., Uemura E., and Greenlee, H. W. (2004). Glucose insufficiency alters neuronal viability and increases susceptibility to glutamate toxicity. Brain Res. 1004, 188-192.

Jahr, C. E., and Stevens, C. F. (1987). Glutamate activates multiple single channel conductances in hippocampal neurons. Nature 325, 522-525.

Jayalakshmi, K., Sairam, M., Singh, S. B., Sharma, S. K., Ilavazhagan, G., and Banerjee, P. K. (2005). Neuroprotective effect of N-acetyl cysteine on hypoxia-induced oxidative stress in primary hippocampal culture. Brain Res. 1046, 97-104.

Kline, R. H., Wright, J., Fox, K. M., and Eldefrawi, M. E. (1990). Synthesis of 3-arylecgonine analogues as inhibitors of cocaine binding and dopamine uptake. J. Med. Chem. 33, 2024-2027.

Kovacic, P. (2005). Unifying mechanism for addiction and toxicity of abused drugs with application to dopamine and glutamate mediators: Electron transfer and reactive oxygen species. Med. Hypotheses 65, 90-96.

Lendvai, B., and Vizi, E. S. (2008). Nonsynaptic chemical transmission through nicotinic acetylcholine receptors. Physiol. Rev. 88, 333-349.

Lepsch, L. B., Munhoz, C. D., Kawamoto, E. M., Yshii, L. M., Lima, L. S., Curi-Boaventura, M. F., Salgado, T. M., Curi, R., Planeta, C. S., and Scavone, C. (2009). Cocaine induces cell death and activates the transcription nuclear factor kappa-B in PC12 cells. Mol. Brain 2.

Liu, Y., Peterson, D. A., Kimura, H., and Schubert, D. (1997). Mechanism of cellular 3-(4,5-dimethylthiazol-2-yl)-2,5-diphenyltetrazolium bromide (MTT) reduction. J. Neurochem. 69, 581-593.

Marsden, J., Eastwood, B., Bradbury, C., Dale-Perera, A., Farrel, M., Hammond, P., Knight, J., Randhawa, K., and Wright, C. (2009). Effectiveness of community treatments for heroin and crack cocaine addiction in England: A prospective, in-treatment cohort study. Lancet 374, 1262-1270.

Martin, B. R., Lue, L. P., and Boni, J. P. (1989). Pyrolysis and volatilization of cocaine. J. Anal. Toxicol. 13, 158-162.

Melo, E. S., Barbeiro, D. F., Gorjão, R., Rios, E. C. S., Vasconcelos, D., Velasco, I. T., Szabo, C., Curi, R., Lima-Salgado, T. M., and Soriano, F. G. (2010). Gene expression reprogramming protects macrophage from septic-induced cell death. Mol. Immunol. 47, 2587-2593.

Mosmann, T. (1983). Rapid colorimetric assay for cellular growth and survival: Application to proliferation and cytotoxicity assays. J. Immunol. Methods $\mathbf{6 5}, 55-63$.

Nakahara, Y., and Ishigami, A. (1991). Inhalation efficiency of free-base cocaine by pyrolysis of 'crack' and cocaine hydrochloride. J. Anal. Toxicol. 15, 105-109.

Niu, L., Abood, L. G., and Hess, G. P. (1995). Cocaine: Mechanism of inhibition of a muscle acetylcholine receptor studied by a laser-pulse photolysis technique. Proc. Natl. Acad. Sci. U.S.A. 92, 12008-12012.

Oliveira, L. G., and Nappo, S. A. (2008). Characterization of the crack cocaine culture in the city of São Paulo: A controlled pattern of use. Rev. Saude Publ. 42, 664-671.

Otmakhova, N. A., and Lisman, J. E. (1996). D1/D5 dopamine receptor activation increases the magnitude of early long-term potentiation at CA1 hippocampal synapses. J. Neurosci. 16, 7478-7486.

Pavarin, R. M. (2006). Substance use and related problems: A study on the abuse of recreational and not recreational drugs in Northern Italy. Ann. Ist Super Sanità 42, 477-484. 
Paul, B. D., Lalani, S., Bosy, T., Jacobs, A. J., and Huestis, M. A. (2005). Concentrations profiles of cocaine, pyrolytic methyl ecgonidine and thirteen metabolites in human blood and urine: Determination by gas chromatographymass spectrometry. Biomed. Chromatogr. 19, 677-688.

Poon, H. F., Abdullah, L., Mullan, M. A., Mullan, M. J., and Crawford, F. C. (2007). Cocaine-induced oxidative stress precedes cell death in human neuronal progenitor cells. Neurochem. Int. 50, 69-73.

Reid, M. S., Flammino, F., Howard, B., Nilsen, D., and Prichep, L. S. (2006). Topographic imaging of quantitative EEG in response to smoked cocaine self-administration in humans. Neuropsychopharmacol. 31, 872-884.

Scheidweiler, K. B., Plessinger, M. A., Shojaie, J., Wood, R. W., and Kwong, T. C. (2003). Pharmacokinetics and pharmacodynamics of methylecgonidine, a crack cocaine pyrolyzate. J. Pharmacol. Exp. Ther. 307, 1179-1187.

Schilström, B., Yaka, R., Argili, E., Suvarna, N., Schumann, J., Chen, B. T., Carman, M., Singh, V., Mailliard, W. S., Ron, D., et al. (2006). Cocaine enhances NMDA receptor-mediated currents in ventral tegmental area cells via dopamine D5 receptor-dependent redistribution of NMDA receptors. $J$. Neurosci. 26, 8549-8558.

Seo, D-W., Lopez-Meraz, M-L., Allen, S., Wasterlain, C. G., and Niquet, J. (2009). Contribution of a mitochondrial pathway to excitotoxic neuronal necrosis. J. Neurosci. Res. 87, 2087-2094.

Shih, Y-T., Chen, P. S., Wu, C-H., Tseng, Y-T., Wu, Y-C., and Lo, Y-C. (2010). Arecoline, a major alkaloid of the areca nut, causes neurotoxicity through enhancement of oxidative stress and suppression of the antioxidant protective system. Free Radic. Biol. Med. 49, 1471-1479.
Silva, R. F. M., Falcão, A. S., Fernandes, A., Gordo, A. C., Brito, M. A., and Brites, D. (2006). Dissociated primary nerve cell cultures as models for assessment of neurotoxicity. Toxicol. Lett. 163, 1-9.

Sim, M. E., Lyoo, I. K., Streeter, C. C., Covell, J., Sarid-Segal, O., Ciraulo, D. A., Kim, M. J., Kaufman, M. J., Yurgelun-Todd, D. A., and Renshaw, P. F. (2007). Cerebellar gray matter volume correlates with duration of cocaine use in cocaine-dependent subjects. Neuropsychopharmacol. 32, 2229-2237.

Smith, D. A., Browning, M., and Dunwiddie, T. V. (1993). Cocaine inhibits hippocampal long-term potentiation. Brain Res. 608, 259-265.

Volkow, N. D., Fowler, J. S., and Wang, G-J. (2004). The addicted human brain viewed in the light of imaging studies: Brain circuits and treatments strategies. Neuropharmacology 47, 3-13.

Woolf, J. H., Huang, L., Ishiguro, Y., and Morgan, J. P. (1997). Negative inotropic effect of methylecgonidine, a major product of cocaine base pyrolysis, on ferret and human myocardium. J. Cardiovasc. Pharmacol. 30, 352-359.

Yuan, C., and Acosta, D. Jr. (2000). Effect of cocaine on mitochondrial electron transport chain evaluated in primary cultures of neonatal rat myocardial cells and in isolated mitochondrial preparations. Drug Chem. Toxicol. 23, 339-348.

Zaragoza, A., Díez-Fernández, C., Alvarez, A. M., Andrés, D., and Cascales, M. (2001). Mitochondrial involvement in cocaine-treated rat hepatocytes: Effect of N-acetylcysteine and deferoxamine. Br. J. Pharmacol. 132, 1063-1070.

Zhang, C., Lomenzo, S. A., Ballay, C. J., II, and Trudell, M. L. (1997). An improved synthesis of (+)-2-tropinone. J. Org. Chem. 62, 7888-7889. 
ANEXO 4 
Fanus - Sistema Administrativo da Pós-Graduação

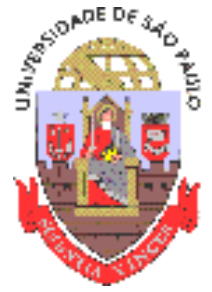

\author{
Universidade de São Paulo \\ Faculdade de Medicina
}

Documento sem validade oficial

FICHA DO ALUNO

\begin{abstract}
5160 - 5363602/1 - Livia Mendonca Munhoz Dati
Email:

liviadati@usp.br

Data de Nascimento:

20/02/1986

Cédula de Identidade:

RG - 439154868 - SP

Local de Nascimento:

Estado de São Paulo

Nacionalidade:

Brasileira

Graduação:

Bacharel em Gerontologia - Escola de Artes, Ciências e Humanidades Universidade de São Paulo - Brasil - 2009
\end{abstract}

\title{
Curso:
}

Mestrado

Programa:

Ciências (Fisiopatologia Experimental)

Área:

Fisiopatologia Experimental

Data de Matrícula:

28/09/2009

Início da Contagem de Prazo:

28/09/2009

Data Limite:

$28 / 09 / 2012$

Orientador:

Prof(a). Dr(a). Tania Marcourakis - 28/09/2009 até o presente. E.Mail: tmarcour@usp.br

Proficiência em Línguas:

Inglês, Aprovado em 09/09/2009

Data de Aprovação no Exame de Qualificação:

Aprovado em 26/09/2011

Data do Depósito do Trabalho:

Título do Trabalho:

Data Máxima para Aprovação da

\section{Banca:}

Data de Aprovação da Banca:

Data Máxima para Defesa:

Data da Defesa:

Resultado da Defesa:

Histórico de Ocorrências:

Ingressou no Mestrado em 28/09/2009

Matrícula de Acompanhamento em 17/07/2012

Aluno matriculado nas normas vigentes a partir de 01/07/2009

Última ocorrência: Matrícula de Acompanhamento em 17/07/2012

Impresso em: 10/09/12 14:50:03 
Fanus - Sistema Administrativo da Pós-Graduação

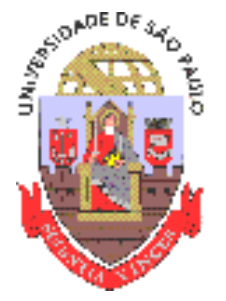

\author{
Universidade de São Paulo \\ Faculdade de Medicina \\ Documento sem validade oficial \\ FICHA DO ALUNO
}

\title{
5160 - 5363602/1 - Livia Mendonca Munhoz Dati
}

\begin{tabular}{|c|c|c|c|c|c|c|c|c|c|}
\hline Sigla & Nome da Disciplina & Início & Término & $\begin{array}{c}\text { Carga } \\
\text { Horária }\end{array}$ & Cred & Freq & Con & Exc & Situação \\
\hline $\begin{array}{c}\text { MNE5758- } \\
1 / 1\end{array}$ & Tráfego Intracelular e Neurodegeneração & $19 / 10 / 2009$ & $901 / 11 / 2009$ & 60 & 4 & 100 & A & $\mathrm{N}$ & Concluída \\
\hline $\begin{array}{c}\text { BMB5795- } \\
3 / 2\end{array}$ & Neurofisiologia Básica & $04 / 03 / 2010$ & 13/05/2010 & 120 & 8 & 100 & A & $\mathrm{N}$ & Concluída \\
\hline $\begin{array}{c}\text { FBC5783- } \\
1 / 3\end{array}$ & $\begin{array}{l}\text { Influência de Fatores Externos nos } \\
\text { Mecanismos de Neurodegeneração } \\
\text { (Faculdade de Ciências Farmacêuticas - } \\
\text { Universidade de São Paulo) }\end{array}$ & $01 / 06 / 2010$ & 05/07/2010 & 45 & 3 & 100 & A & $\mathrm{N}$ & Concluída \\
\hline $\begin{array}{l}\text { BMB5788- } \\
\quad 5 / 1\end{array}$ & Comunicação Celular no Sistema Nervoso & $19 / 08 / 2010$ & 14/10/2010 & 90 & 6 & 87,5 & A & $\mathrm{N}$ & Concluída \\
\hline
\end{tabular}

\begin{tabular}{|l|c|c|c|}
\hline & \multicolumn{2}{|c|}{ Créditos mínimos exigidos } & Créditos obtidos \\
\hline & Para exame de qualificação & Para depósito da dissertação & \\
\hline Disciplinas: & 8 & 16 & 21 \\
\hline Estágios: & 8 & 16 & 21 \\
\hline Total: & 8 & & 216 \\
\hline
\end{tabular}

\section{Créditos Atribuídos à Dissertação: 80}

\section{Conceito a partir de 02/01/1997:}

A - Excelente, com direito a crédito; B - Bom, com direito a crédito; C - Regular, com direito a crédito; R - Reprovado; $T$ - Transferência.

Um(1) crédito equivale a 15 horas de atividade programada.

Última ocorrência: Matrícula de Acompanhamento em 17/07/2012

Impresso em: 10/09/12 14:50:03 
ANEXO 5 


\section{Lívia Mendonça Munhoz Dati}

Endereço para acessar este CV: http://lattes.cnpq.br/7315740155833327

Última atualização do currículo em 10/09/2012

Possui graduação em Gerontologia pela Escola de Artes, Ciências e Humanidades (2008). (Texto informado pelo autor)

\section{Identificação}

\section{Nome}

Lívia Mendonça Munhoz Dati

\section{Nome em citações bibliográficas}

DATI, L. M. M. ;Dati, L. M. M.

\section{Sexo}

Feminino

\section{Endereço}

\section{Endereço Profissional}

Faculdade de Medicina.

Rua Teodoro Sampaio

Pinheiros

05405-000 - Sao Paulo, SP - Brasil

\section{Formação acadêmica/titulação}

2009

Mestrado em andamento em Fisiopatologia Experimental.

Universidade de São Paulo, USP, Brasil.

Título: CAracterização das vias de morte celular induzida pela metilecgonidina, produto da pirólise da cocaína., Orientador: Tania Marcourakis.

Bolsista do(a): Fundação de Amparo à Pesquisa do Estado de São Paulo, FAPESP, Brasil.

$2004-2008$

Graduação em Gerontologia.

Escola de Artes, Ciências e Humanidades. 


\section{Atuação Profissional}

Universidade de São Paulo, USP, Brasil.

\section{Vínculo institucional}

2009 - Atual

Vínculo: Universidade de São Paulo, Enquadramento Funcional: Mestranda, Regime: Dedicação exclusiva.

\section{Vínculo institucional}

$2007-2008$

Vínculo: livre, Enquadramento Funcional: iniciação cinetífica, Carga horária: 20, Regime: Dedicação exclusiva.

\section{Projetos de pesquisa}

2009 - Atual

Caracterização das vias de morte neuronal induzida por metilecgonina, produto da pirolise da cocaína

Situação: Em andamento; Natureza: Pesquisa.

Integrantes: Lívia Mendonça Munhoz Dati - Coordenador.

Financiador(es): Fundação de Amparo à Pesquisa do Estado de São Paulo - Bolsa.

\section{Áreas de atuação}

\section{Idiomas}

\section{Inglês}

Compreende Razoavelmente, Fala Razoavelmente, Lê Bem, Escreve Razoavelmente. 
Menção Honrosa para o trabalho Caracterização das vias de morte celular induzida pela metilecgonidina, produto da pirólise da cocaína., XXV Reunião Anual da FeSBE, Federação de Sociedades de Biologia Experimental..

\title{
Produções
}

\author{
Produção bibliográfica
}

\section{Artigos completos publicados em periódicos}

Ordenar por

Ordem Cronológica

1.

Larissa ; QUAGLIO, N ; SOUZA, G. T. ; GARCIA, R. C. T. ; DATI, L. M. M. ; MOREIRA, W. L. ; LOUREIRO, A. P. M. ; SOUZA-TALARICO, J. N. ; SMID, J. ; POROT, C. S. ; BOTTINO, C. M. C. ; NITRINI, R. ; BARROS, S. B. M. ; CAMARINI, R. ; MARCOURAKIS, T. . Peripheral Oxidative Stress Biomarkers in Mild Cognitive Impairment and Alzheimer s Disease.. Journal of Alzheimer's Disease JCR , v. 26, p. 59-68, 2011.

Citações: scopus 4

\section{Artigos aceitos para publicação}

1.

Garcia, R. C. T. ; DATI, L. M. M. ; YONAMINE, M. ; FUKUDA, S. ; Neto, O. N. ; MOURA, S. ; MARCOURAKIS, T. ; CAMARINI, R. ; Afeche, S. C. ; Levada-Pires, A. C. ; Torres, L. H. L. ; Abdalla, F. M. F. ; Carrettiero, D. C. ; de Carvalho, N. D. ; Negrini-Neto, O. ; Sandoval, M. R. L. . Neurotoxicity of Anhydroecgonine Methyl Ester, a Crack Cocaine Pyrolysis Product. Toxicological Sciences (Print) JCR, 2012.

\section{Apresentações de Trabalho}

1.

DATI, L. M. M. ; GARCIA, R. C. T. ; Larissa ; SANDOVAL, M.R.L. ; AFECHE, S. ; ABDALLA, F.M.F. ; CURI, R. ; MARCOURAKIS, T. . Ação muscarínica induzida pela metilecgonidina, produto de pirólise da cocaína, durante o processo de morte neuronal. . 2011. (Apresentação de Trabalho/Congresso).

2. 
GARCIA, R. C. T. ; DATI, L. M. M. ; Larissa ; COSTA, J.L. ; CAMARINI, R. ; AFECHE, S. ; SANDOVAL, M.R.L. ; MARCOURAKIS, T. . Participação da metilecgonidina (AEME) na dependência ao crack. . 2011. (Apresentação de Trabalho/Congresso).

\section{3.}

GARCIA, R. C. T. ; DATI, L. M. M. ; MORAES, T.A. ; COSTA, J.L. ; Larissa ; DORR, F.A. ; YONAMINE, M. ; CAMARINI, R. ; FLORIO, J.C. ; AFECHE, S. ; SANDOVAL, M.R.L. ; MARCOURAKIS, T. . Is methylecgonidine involved on crack cocaine addiction. . 2011. (Apresentação de Trabalho/Congresso).

\section{4.}

DATI, L. M. M. ; GARCIA, R. C. T. ; Larissa ; SANDOVAL, M.R. L. ; AFECHE, S. ; ABDALLA, F.M.F. ; DORR, F.A. ; COSTA, J.L. ; CURI, R. ; MARCOURAKIS, T. . Involvement of muscaniric receptors on neurotoxicity of methylecgonifdine, pyrolisis product of cocaine.. 2011. (Apresentação de Trabalho/Congresso).

\section{5.}

GARCIA, R. C. T. ; Larissa ; DATI, L. M. M. ; FUKUDA, S. ; MOURA, S. ; SANDOVAL, M.R.L. ; AFECHE, S. ; MARCOURAKIS, T. . Neurotoxicidade da metilecgonidina (AEME) e da cocaína (COC): o estresse oxidativo como mecanismo de morte celular.. 2009. (Apresentação de Trabalho/Congresso).

\section{Eventos}

\section{Participação em eventos, congressos, exposições e feiras}

1.

XVII Congresso Brasileiro de Toxicologia.Ação muscarínica induzida pela metilecgonidina, produto de pirólise da cocaína, durante o processo de morte neuronal.. 2011. (Congresso).

2.

Neuroscience. Is methylecgonidine involved on crack cocaine addiction.. 2011. (Congresso).

3.

XXV Reunião Anual da FeSBE, Federação de Sociedades de Biologia Experimental. .Caracterização das vias de morte celular induzida pela metilecgonidina, produto da pirólise da cocaína.. 2010. (Seminário).

4. 
XVI Congresso Brasileiro de Toxicologia. Neurotoxicidade da metilecgonidina (AEME) e da cocaína (COC): o estresse oxidativo como mecanismo de morte celular.. 2009. (Congresso).

\section{5.}

XXIII Reunião Anual da Federação de Sociedade de Biologia Experimental-FeSBE. Ácidos Graxos e Balanço Redox em Células Beta Pancreáticas-RINm5F. 2008. (Congresso).

6.

16 SIICUSP- Simpósio Internacional de Iniciação Científica da USP.Ácido Graxos e Balanço Redox em Células Beta Pancreáticas-RINm5F. 2008. (Simpósio).

7.

III Jornada do Núcleo de envelhecimento cerebral. 2008. (Encontro).

8.

5 Congresso Paulista de Geriatria e Gerontologia. 2007. (Congresso).

9.

5 Congresso Paulista de Geriatria e Gerontologia. Novas Perspectivas para atuação do Gerontólogo. 2007. (Congresso).

10.

Envelhecimento de População Brasileira: Desafio para o Estado, Sociedade e Família. 2007. (Seminário).

11.

A Realidade dos Asilos. 2007. (Seminário).

12.

XI Curso Introdutório à Liga de Geriatria da FMUSP. 2007. (Simpósio).

13.

III Simpósio sobre ácidos graxos e saúde. 2007. (Simpósio).

14. 
II Simpósio Temático de Departamento de Físiologia e Biofísica "Aspectos Fisiologicos da Atividade Física". 2007. (Simpósio).

15.

Simpósio Internacional sobre Cuidados Paliativos. 2007. (Simpósio).

16.

II Simpósio Retrospectiva e Perspectivas da Fisiologia. 2007. (Simpósio).

17.

Curso de Treinamento no Uso de Animais de Experimentação. 2007. (Oficina).

18.

Palestra Velhice e Vulnerabilidade: Enfoque Multidisciplinar. 2007. (Encontro).

19.

I Joranda de Gerontologia. 2007. (Outra).

20.

III Curso de Inverno-Alimentação: do Habito à célula.organização. 2007. (Outra).

21.

2 Seminário de Pesquisa em Gerontologia da UNICAMP. 2006. (Seminário).

22.

I Jornada de Núcleo de Envelhecimento Cerebral NUDEC. 2006. (Seminário).

23.

III Simpósio de Geriatria e Gerontologia da FCM/ UNICAMP. 2006. (Simpósio).

24.

Reunião de Pesquisa pela Câmara de Pesquisa do Hospital Universitário da Universidade de São Paulo. 2006. (Encontro). 
25.

Liga de Gerontologia. 2005. (Simpósio).

Página gerada pelo Sistema Currículo Lattes em 11/09/2012 às 13:46:03

Imprimir currículo 